\title{
Coleccionismo y devociones domésticas en la Sierra de Francia y Candelario (Salamanca, siglos XVII-XIX)
}

\author{
A M.a Dolores y Pilar, \\ "testigas y apóstolas" de la Sierra de Francia
}

Las devociones y su iconografía no vienen solas, se presentan arropadas por los conceptos estéticos de cada época y los materiales y técnicas que agrupan las obras en familias (retrato, imagen, figura, hechura de bulto, pintura, etc.).

En los documentos que estudiamos (testamentos, inventarios, partijas, dotes) no se precisan por igual cada uno de los elementos, necesarios para la plena identificación de la pieza: en unos textos los escribanos y veedores detallan minuciosamente los atributos de los santos y las escenas que se representan, en otros tasan la pieza atendiendo sólo a su valor material o a la guarnición externa (marcos, umas, escaparates, y otras alhajas). De hecho abundan en los documentos las imprecisiones, cuando no la confusión de conceptos que oscurece la clasificación de la obra.

Para unas familias estos objetos domésticos parecen solo excusa al incremento patrimonial por medio de las colecciones. Otras, en cambio, acogen las devociones sin otra pretensión que la de formar su particular panteón familiar.

De este análisis documental se obtiene como resultado la polarización de dos conceptos, la forma y la devoción, que, desenmarañados, intentamos armonizar. Para ello se desglosa el presente trabajo en dos partes bien diferenciadas: a la primera corresponden los conceptos y las formas, a la otra, el desarrollo iconográfico.

\section{EL CONCEPTO Y LA FORMA}

\section{El retrato}

Subraya Covarrubias el carácter de personaje "principal que otorga la sociedad al retratado, como cosa necesaria para serlo, y la fiel correspondencia entre la captatio y la persona de la que se toma la figura. Se busca como objetivo fundamental la preservación de la "memoria" de ese rostro a los siglos venideros. Sobre cualquier otra intención deberá primar la no distor- 


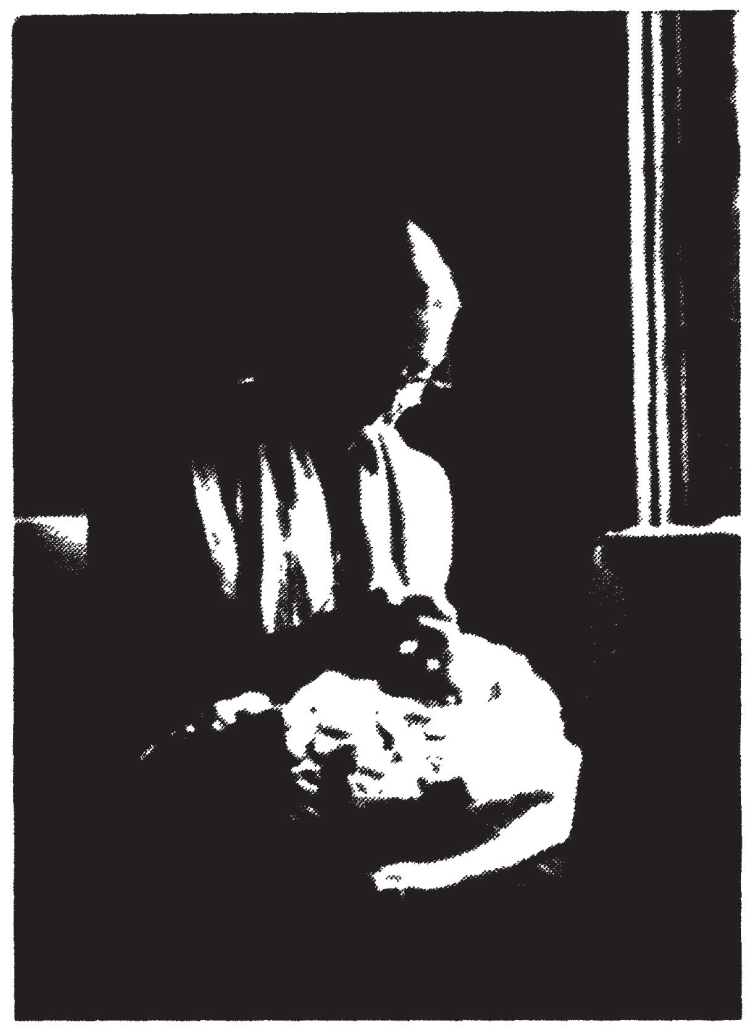

LÁM. I.-Escena doméstica en Mogarraz, al fondo el grabado de Ntra. S. de Francia, obra de Félix Prieto, Salamanca, 1781. (Foto, A. Cea, 1978).

sión de la realidad. En ese sentido, describe también Covarrubias como cualidad del "retratador", el que la imagen que se forma del original se saque "enteramente parecida", ya sea pintada, esculpida o grabada, por este orden de materiales y técnicas.

Menos perfilada queda la definición de retrato en Autoridades: "La pintura o efigie que representa a alguna persona" - de nuevo se subraya aquí la modalidad pintada como característica del retrato- sustituyendo su presencia y de tal manera ajustada a la realidad que parezca devuelta a la vida.

En ninguno de los diccionarios va relacionada la voz retrato con personajes celestiales, solo "principales y de cuentan. Principales y de cuenta son los cinco personajes (un fundador de capellanía, dos hacendados devotos, un santo y la mujer de un escribano) cuyos retratos quedan inventariados entre los años 1671 y 1863 respectivamente. Se presenta clasificada esta pintura por su denominación en tres variables: como cuadro-retrato, como retrato y como retrato en fotografia.

Como cuadro-retrato en el caso del fundador de Capellanía. Como retrato, los de Juan Mercado, Juan Fernández del Tablado y el de aSanto Domingo sin marcom. Este último o se tenía por obra en todo semejante al natural o presentaba al santo sin las insignias de santidad. El último ejemplo y más curioso: "el retrato de la difunta y el enunciado en fotogrfía y marco dorado", corresponde a un inventario de Candelario del año 1863, momento en el que el retrato va ya siendo desplazado. Se trata en realidad de una fotografía que mantiene la estructura del retrato: figura y leyenda ( enunciado"). Es evidente aquí la transgresión por cruce de conceptos, mantenida hasta hoy entre la gente llana cuando llama a la fotografía retrato, confundiéndolos. Ėn rigor, no se traiciona la fórmula vieja, pues no puede hallarse mayor semejanza de la persona que con la fotografía, y, por ello, se cumple al dedillo la definición del Covarrubias, dos siglos y medio antes de que fuera "retratada" en Candelario la difunta de Don Tomás Pantaleón Rico. 
Que se perpetuase la memoria, la constancia y, en nuestro caso, la veneración por los siglos venideros, debió ser el origen de los que se tienen por "verdaderos retratos", vera effigies, "rostros divinos" $\mathrm{y}$ "verónicas" de Cristo y María, de adscripción apostólica los más de ellos y atribuidos en especial a San Lucas quien, según tradición, los tomaría del natural.

En la pintura y escultura de tema religioso, sobre todo de devoción, pocas veces podría hablarse con rigor de retrato si no admitimos los ya expresados como de procedencia divina o prodigiosa, y salvedad hecha de los escasos ejemplos de santos que fueron retratados en vida, aquellos de los que se sacó mascarilla o los que permanecen incorruptos". Los llamados "verdaderos retratos" (grabados, estampas, pinturas, etc.) de advocaciones locales, especialmente marianas, re-

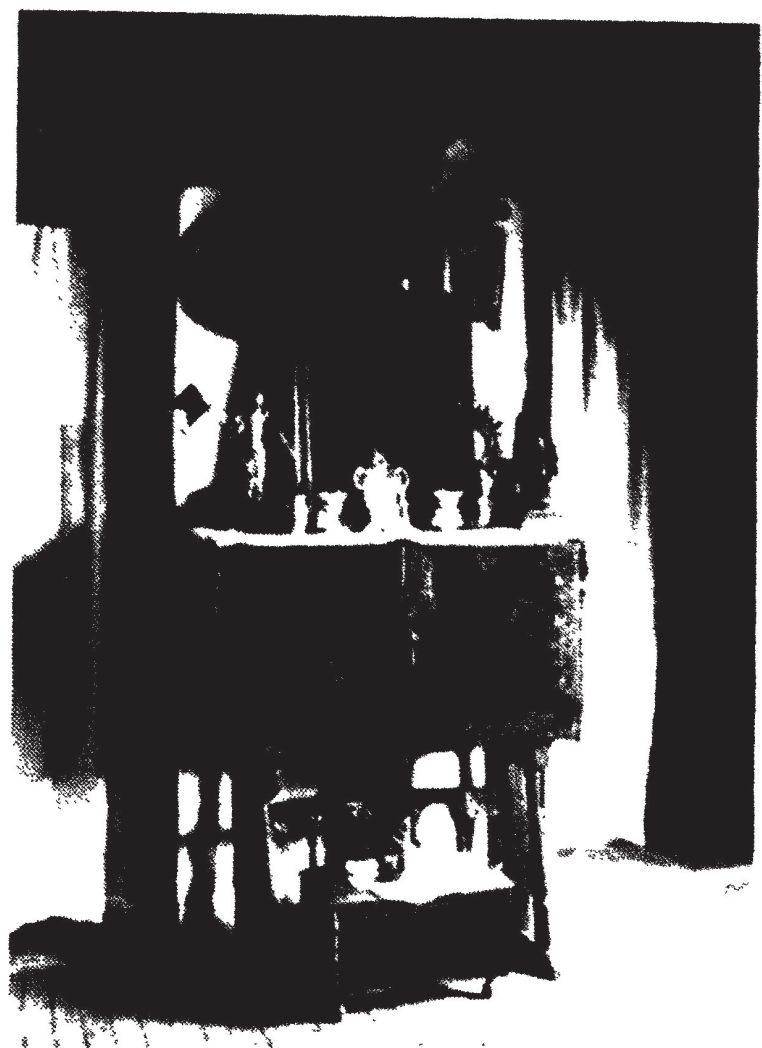

LÁM. II.-Casa albercana. Sobre el bargueño una pintura de Niño Jesús (s. Xvil) con los emblemas de la Pasión en la mandila. A los lados, un Resucitado o "Aleluya" con su veleta y una Concepción, tallas en madera. (La Alberca, s. Xvil; col. part. Foto, M. Jesús del Amo, 1993). tratan casi siempre en todo la verdad del entorno, si no las caras: retablo, camarín donde se venera la devoción, vestidos y joyas con que se adoma, cortinajes y otras guarniciones votivas de la imagen. Por esa piedad "verificada" o retratada en la estampa recompensan los prelados a los fieles con indulgencias, como si lo hicieran ante la figura verdadera, según reza en las leyendas o pies impresos, junto al título, profesión milagrera, lugar de culto, año de ejecución de la obra y autoría.

También debemos suponer a veces retrato verdadero la figura del donante en los exvotos pintados, por torpe que sea la mano del santero.

Por lo dicho anteriormente se conviene que el retrato hagiográfico es verdadero cuando se utilizan todos o al menos los más diferenciantes tics, iconográficamente destinados a reconocer la identidad individualizada de

1 Quizá el retrato de Santa Teresa realizado por fray Juan de la Miseria sea uno de los ejemplos más característicos. Nunca sabremos si el reproche de la santa, debido a la falta de correspondencia entre el natural y la obra. fue impericia del pintor o debilidad femenina. 
cada santo personaje. Nunca podrán ser confundidos con otro y serán a su vez clasificados en jerarquías de virtud por señales comunes.

Señalamos aquí los apartados que suelen utilizarse en la identificación de los santos y que denominariamos perfiles para el retrato.

A) Por los rasgos somáticos. Ejemplo indicativo es el de los apóstoles Pedro y Pablo, generalmente geminados, y reconocibles solo con que se presenten sus cabezas. La de San Pedro responde a una constitución pícnica, el pelo escaso y en cerquillo y la barba casi siempre en tres haces. La cabeza de San Pablo, en cambio, es atlética, los cabellos más poblados y barba larga y aguzada.

B) Por la edad. El grupo de santos que tiene como distintivo común ser cristóforos (Antonio de Padua, Cayetano, Luis Gonzaga, Estanislao de Kostka, José de Nazaret, etc.), cuando aparecen solo de busto, necesitan ser diferenciados primero por la edad y la disposición de los cabellos, y luego por el vestido o los atributos como la vara de azucenas, aunque en este caso y por sí sola confundiría, al ser compartida al menos por tres de estos personajes.

C) Por la indumentaria. Las prendas litúrgicas, especialmente las de cabeza, posibilitan la distinción en jerarquías: la mitra para los obispos, el capelo para los cardenales y para el papa, la tiara, aunque un papa pueda también llevar mitra cuando se representa como oficiante.

La ropa talar o el hábito de cada religión -eremítica, monástica o conventual- podría ayudamos a distinguir en el apartado B a San Cayetano de San Antonio, aunque no a San Luis de San Estanislao, al ser ambos jesuitas.

La ropa secular o del siglo marca las modas de cada momento. En este caso mientras unos santos se adscriben a modelos siempre arcaizantes, otros, en cambio, como Magdalena, Catalina o el Rey Mago Baltasar, son siempre representados con indumentaria innovadora.

D) Por los atributos. Generalmente el elemento emblematizado que más destaque entre los pasajes biográficos, o el instrumento propio de cada martirio; si bien en esta jerarquía no suele faltar el común a todos ellos, la palma. A veces, incluso distintos atributos son la medida en etapas de la vida del santo. Así, el tarro de los perfumes de Magdalena marca su etapa disoluta y la calavera, en cambio, la penitente, pero si se pretende señalar la visión globalizada ambos atributos se disponen juntos.

E) Por la gestualidad. La sola indicación de la mano derecha en actitud de bendecir diferencia como propias la del presbítero de la del obispo y esta 
de la del papa. Todas tres esconden tras la palma el pulgar. El primero bendice con los cuatro dedos restantes, el obispo con el anular, corazón e índice levantados, y la manera pontifical debe mantener en alto solo los dos últimos.

\section{La imagen}

Aludiendo directamente a lo sagrado y con una intencionalidad bien distinta de la del retrato, define Autoridades, en una primera acepción la voz imagen como: «Figura, representación, semejanza y apariencia de alguna cosa. Se llama también - según el mismo diccionario- la estatua, efigie o pintura de Christo, Señor Nuestro, de María o los Santos, que los representa y los da a conocer". En una tercera acepción se describe la imagen con "un rostro perfecto" al que el artífice procura sla mayor perfección y delicadeza. que puede sin atender a retratar.

La acomodación con la realidad que exigía el retrato se sustituye ahora por la visión idealizada, tanto más aceptada a los ojos de la jerarquía cuanto más mueva esa imagen a devoción y arrepentimiento, sirva de ejemplo edificante y se obtengan de ella los mayores logros catequéticos.

Canaliza la imagen los ideales de belleza de cada época y aún en los momentos del realismo más exagerado ello no supone en modo alguno mayor fidelidad entre el original y la figura que se representa.

Servirá sobre todo como libro abierto a la memoria y espejo de virtudes que el cristiano debe imitar. En esos términos se expresa el Covarrubias: -Comúnmente entre los fieles católicos llamamos imágenes las figuras que nos representan a Christo [...], a su benditísima Madre [...], a sus apóstoles y a los demás santos [...] en quanto pueden ser imitados y representados, para que refresquemos en ellos la memoria, y la gente ruda, que no sabe de letras, les sirven de libro.

Ese declarado no verismo quizá lograba en el devoto uno de los dos fines arriba deseados: el de la representación dignificada, pero dudamos que los rasgos de belleza sin límite dejaran con fuerzas a quien intentara imitarlos.

La imagen, en suma, no atiende a la correspondencia con el rostro que representa, lo perfecciona y desnaturaliza suavizándolo para que, en expresión de Covarrubias, sirva a las gentes de lectura ejemplarizante por medio de la escultura y la pintura en este orden. Así lo comprobamos también por documentación serrana, donde se advierte un número de ejemplos mayor y más rico en imágenes de bulto que pintadas.

Se enumeran de una parte: Imágenes de bulto sin especificar más, de bulto dorado, de busto, imágenes de escultura y de talla dorada y estofada. Respecto a las pintadas, podemos establecer las variantes siguientes: imáge- 
nes-estampa, pintadas en papel, e imágenes en cuadro (una de estas con la devoción de N. ${ }^{a}$ S. ${ }^{a}$ del Pópulo) ${ }^{2}$.

\section{La efigie}

Según esto la voz efigie: "Imagen, figura, bulto y hechura semejanten, que define Autoridades, vendría más cercana al concepto de retrato que al de imagen si aquel se inclina hacia la verdad y no al halago y la intencionalidad edificante. Quizá por ello distinga la iconografía entre la efigie y la vera effigies o auténtica manifestación de la cara de Dios y de la de María.

\section{La figura}

Si nos atenemos a la tercera acepción que de la figura da Autoridades como ula estatua o pintura con que se representa el cuerpo, de algún hombre o animal", posiblemente estaremos aceptando el marco más impreciso de cuantos se describen en los diccionarios contemporáneos a la documentación que nos ocupa.

Coinciden Covarrubias y Autoridades al definir la figura solo "por el rostro por ser la principal parte en la cual nos diferenciamos unos de otros". La expresión poderosa de la cabeza (esculpida o pintada) nos diferencia y nos hace, a la vez, reconocibles. El resto del cuerpo parece, según esto, solo pedestal en que aquella se asienta.

Aunque no se alude con esta voz a la representación sagrada, de hecho, en abundantes documentos, cristos, vírgenes y santos aparecen descritos como figuras sin más, figuras de bulto, talla y escultura.

Como figuras de yeso hemos documentado quince ejemplos, relativos a las advocaciones de San José, Santa Ana, Niño Jesús, Nuestra Señora, Verónica, Crucifijo y otros santos sin especificar, oscilando los precios entre dos y cuatro reales y fechados en la segunda mitad del siglo XVIII. Aparecen tan sólo dos ejemplos de figuras de cera: "un san Juan de cera la echura", en inventario de Cepeda y año 1642 y otro, también de San Juan, en Sequeros en el año 1742, ambos sin valorar.

2 Durante tiempo, las voces cuadro y marco tuvieron un sentido bidireccional: Relacionadas con la pintura como su guarnición y soporte, al servicio de la imagen de bulto redondo fueron, en cambio, sinónimo de caxa-caja, vidrieras o escaparates. En aquellos documentos donde no se especifican los materiales de la hechura, de poco sirven estas dos palabras a despejar la duda. No es el caso de la romana y muy venerada Virgen del Popolo, advocación, como es sabido, solo y siempre pintada. 
Figuras con la denominación de bulto se citan seis en documento de 1783 , "todas de vulto y de yerro nuevas" (advocaciones del Carmen, San Antonio, San Pedro, y de las santas Bárbara y Teresa). Solo un "San Sebastián de bulto, es de madera". En otros años y documentos se registran un Cristo y dos Nuestras Señoras.

En figura de barro trece ejemplares, de los cuales diez se veneraban en una misma casa: "crucifixo, seis santos pequeños en seis reales, un San Antonio en cinco reales y dos santas Teresas guarnecidas de mano de monxas". Los tres ejemplos restantes no están tasados y son otra Santa Teresa y dos Crucifijos, uno "con su cruz, dorados los cavos y es de barro. Dos figuras de plomo, valorada una en cuatro reales y otras tres de bronce, una con valor de ocho reales; todas son Crucifijos.

En seis ocasiones más se documentan figuras sin especificar los materiales, pero sí los elementos en que van colocadas para su veneración, como son: cajas, vidrieras, peanas, cortinas, cielos y doseles. Una de ellas es una Concepción con su inventario de vestidos, ropas y cerco de plata. La tasación más alta corres-

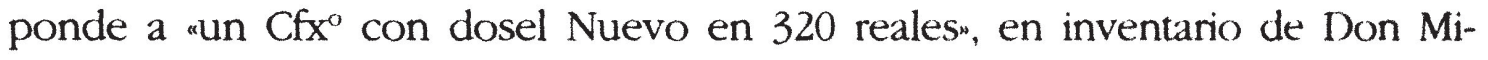
guel de Moreta, Miranda, 1814. Cuando la calidad de las figuras es estimada superior por los tasadores o escribanos se describen como "talla", wechura de talla" o "echura de escultura", todas de madera y madera dorada. Contamos con seis ejemplos: dos de Crucifijos, otros dos de Niños Jesús, un Ecce Homo y un San Jerónimo. Se especifica en algunos documentos, que van embutidos en marcos o cajas. Los Niños Jesús, curiosamente, mantienen el mismo valor, doce reales, aunque un inventario se fecha en 1737 y el otro en 1806 . El precio más alto sube a cincuenta reales por un Crucifijo de talla dorada.

Autoridades define la bechura en una tercera acepción como la efigie, estatua o figura de bulto ya sea de barro, piedra, u otra materia, que regularmente suelen ser de Christo, su Madre, o los Santos".

Estas figuras y el resto de las voces que aquí se consideran: pintura o bechura de pincel, lienzo pintado, paño de pintura, sábana pintada, cuadro, estampa, papel, lámina, vitelo, etc., atienden no al concepto de lo representado sino a su materialización y técnicas.

\section{Pintura y grabados}

Por lo que respecta a las colecciones domésticas de pintura en la Sierra de Francia y Candelario, podemos establecer, si nos atenemos a las referencias documentales, alguna variante bien diferenciada atendiendo a su soporte, medidas, estimación y procedencia, usufructuario, calidad y temática.

En primer lugar están aquellas obras, generalmente con soporte de lienzo, en las que se reconoce una calidad técnica y mérito en su ejecución. Quedan 
inventariadas como epinturan, "pintura de pincel, obra de pintura. y aquadro de pintura finar. Suelen detallarse las medidas, que oscilan en los ejemplos entre la media vara, tres cuartas, una vara, vara y cuarta, vara y media, llegando a alcanzar, los mayores, las dos varas de alto. Se tienen también en cuenta en la valoración los marcos, casi siempre negros, alguno dorado y, los más, negros con sus molduras o tarjetas de oro. No es lo más habitual en estas obras de calidad especificar el tema, como si con la sola definición de "pintura" bastara, aunque parece lógico suponer que predominaran las de tema religioso.

Se enumeran varias "Nuestra Señora", sin más titularidad, alguna "Soledad", "Crucifijo", Niño Jesús" y un "San Jerónimo". Sí se concreta, en cambio, el sujeto cuando es profano: "pintura de países", «lienzos que representan cosas de comer", "pinturas de la casa de Austria", historias de Pablo y Virginia", "de otras historias", "con diferentes pinturas", etc.

El inventario más representativo de obras de pincel en la Sierra corresponde a las partijas de los hijos de Francisco Díez en San Martín del Castañar y año 1742, con doce pinturas valoradas, las más baratas, entre treinta y cuarenta reales, y en sesenta las más caras.

Casi extinguida y de menor consideración era por estos mismos años la pintura sobre tabla o madera. Los dos únicos ejemplos se tasaron en un maravedí y cuatro reales respectivamente.

En cinco inventarios se nombran trece piezas de Valencia entre cuadros, estampas y láminas, ocho de ellas tasadas en cuatro reales cada una, otra en siete y en diez la más cara. Sobre la oferta devocional que presentara esta ciudad, sólo se nos desvela la de "Nuestra Señora del Carmen" y una "Custodia. En partija de Sequeros del año 1745 se documenta por primera y última vez una echura de Sevilla", seguramente de bulto.

Desconocemos si cada uno de estos focos de producción adolecía de estilo propio, aunque sí llegamos a entrever variaciones en la guarnición. Probablemente, y por lo que toca a la hechura sevillana, no parece arriesgado suponer una "maniera" contrapuesta a la de Castilla. Tampoco sabemos si la mayor estimación en el precio de las de Valencia va en proporción directa con la distancia, ni si llegaban los cuadros a la Sierra desde su punto de origen, a través de la arriería, o si se revendían por los tenderos salmantinos.

Menos relacionadas con la procedencia y más con el género a que pertenecían debieron estar equatro quadros de pinturas francesas largas", inventariadas en hijuela de San Martín (1671).

Posiblemente se trataba de cuadros con tema mitológico o historias amatorias como la de Pablo y Virginia, también cuatro, valoradas en doce reales, según inventario del año 1800 en Candelario. 
La mayoría de estos cuadros, con sus marcos, eran esquinados o cuadrados, de ahí su nombre, e incluso con portezuelas, otros, en cambio, sin guarnición, en bastidor o pegados en tablillas".

Queremos señalar la dificultad insalvable por lo escueto o lo generalizante de algunos documentos, para distinguir a veces entre lo pintado y lo grabado, entre la estampa y la lámina para embutir en joya-relicario, o entre el cuadro de monjas y el escaparate.

Se describen estampas con o sin marco: ede papel. sin más, estampas de Valladolid", en papel de marca" o como "papeles de [N. $\left.{ }^{2}{ }^{2}{ }^{2}\right]$ de Franzia" en bastidores. Las más baratas a real y medio y a seis las de seda, nuevas y con su media caña, en ejemplo relativo al año 1760 .

\section{La lámina}

Las láminas vienen mejor descritas. Ofrecen variantes esquinadas, con sus marcos dorados o negros y otras redondas. Están pintadas, además de en papel, en tabla, sobre cobre, hojadelata, en chapa, y sobre vidrio (estas últimas de tamaño de una cuarta), con marcos dorados y apreciadas en el año 1742 en cuarenta reales. Ninguna aparece como de Valladolid y sí tres de Valencia, valoradas en cuatro, diez y veintiocho reales respectivamente. En veintitrés documentos se atestiguan como slaminitas de vitelas", otra "pequeña y redonda con sus vidrieras" es seguramente de relicario. La guarnición puede ser "de cáñamo", oropel", o bordada: ‘bordada con una cinta alredor", "de flores alrededor, colorado y blanco", «bordada de filigrana de plata* y ede hilos de oro y plata y sedas de diferentes colores. Solamente en una laminitarelicario del año 1690 se nos desvela la advocación, que era ede santa Teresa y San Josepe, una por cada vidrio.

Muy asociada y cercana debía estar la pintura en lámina, incluso por su tamaño, a la joya-relicario cuando Autoridades, al definir al laminero, asocia los dos oficios: ‘El que hace láminas y guarnece relicarios de plata, acero $u$ otro metal.

\section{La obra de monjas}

Los llamados equadros de monxas - - no sabemos hasta qué punto pueden identificarse con el selicario en quadro-, marcan el paso entre la pieza plana de pared y el escaparate. Ambos géneros suelen tener idéntica procedencia conventual, a veces con elementos reutilizados y profusa guamición, como la que acabamos de ver para las láminas. Pueden tener hechura de madera, barro, cera, telas, metales, papel, elementos vegetales y mixtos, formando verdaderos collages. Van concebidos como escenas de carácter casi exclusivamente 


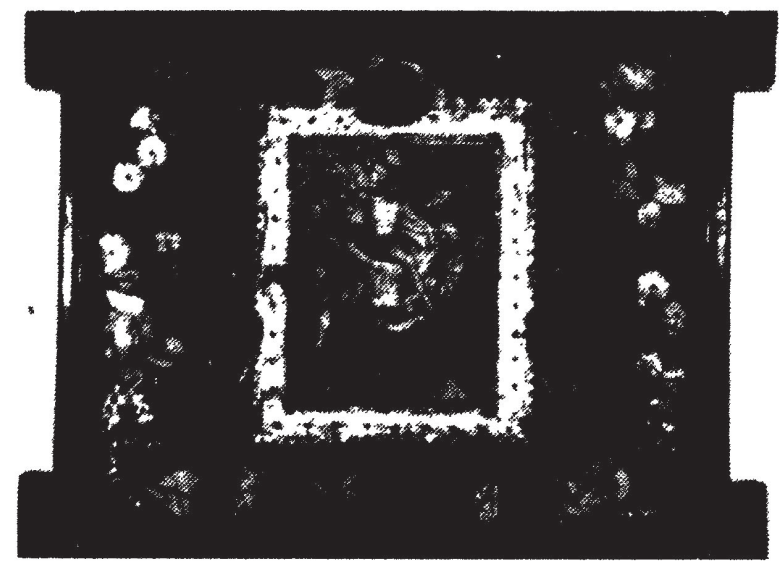

LÁM. III.-Grabado iluminado del Descendimiento con guarnición "de mano de monjas": encaje de oro, platilla, florones y floreros de hojadelata y guirnaldas con rosas de tela y cera, sobre campo de damasco encarnado.

(S. XIX, col. part. Madrid)

religioso o de la vida cotidiana conventual, en una o varias secuencias sobremontadas en el escaparate, a manera de retablillo o teatrino.

En el año 1761 se recogen en inventario "dos quadritos de monxas guarnecidos de platilla en diezyseis realesn. La obra de monjas en cuadros o con figuras de bulto dejaba una impronta abigarradamente primorosa que por sí sola venía a convertirse en género, manera o sello y era reconocida de inmediato, aun ignorando su procedencia, como se demuestra en este inventario donde se dice: "Dos San-

tas Teresas de barro guarnecidas de monxas". El escaparate logra sobrevivir a lo largo del siglo XIX y llega hasta nuestros días como pieza-testigo.

No deben confundirse por su estructura ni funciones el escaparate con la caja y la "urnia". Mientras la caja acoge siempre hechuras de bulto y alguna pintura y la urna, no siempre de madera, mezcla a veces efigies con reliquias, el escaparate puede escapar al contenido estrictamente religioso, y así lo recoge Autoridades: "Alhaja hecha a manera de alhacena o almario, con sus puertas y andenes dentro, para guardar buxerías, barros finos y otras cosas delicadas, de que usan mucho las mujeres en sus salas de estrado para guardar sus dixes".

Hemos de señalar que, si bien en los escaparates que han llegado hasta nosotros, predominantemente de conventos, prima como es lógico el tema de escena sacra o al menos religiosa, con un carácter lúdico, los inventariados en documentación van más de acuerdo con la definición de Autoridades, como puede verse en estos tres ejemplares mirandeños del siglo xvIII que a continuación citamos: "Escaparate con bidrio con diferente enrreditos de barro, regulado en veinte rs" (año 1771). "Escaparate de paxa y en él un rosario de gueso" (1737). "Dos escaparates con varias figuras dentro" (1782).

\section{El vitelo o vitela}

Relacionados con la pintura en relicarios de pared y del cuello están los llamados vitelos o vitelas, todos ellos tras vidrieras y con sus marcos o "maderas. De los veinte ejemplos con que contamos, uno - seguramente de los de pared- lleva "flores enmarcadas adomando alrededor". 
Los propietarios de estas colecciones son casi siempre títulos nobiliarios o académicos, clérigos, comerciantes y campesinos hidalgos poderosos. Cuesta imaginar hoy que esas casas serranas, tan alejadas de la corte, colgaran en sus paredes temas del gusto "al uso de ciudadanos", como los de las dieciochescas historias de Bernardino de Saint Pierre. Que esas obras le resultaran tan familiares al escribano como para reconocerlas mientras recorría las piezas de la casa al hacer inventario, no deja de sorprendernos. Es posible que a veces se guiara en el registro por la leyenda al pie de las pinturas, meticulosidad que de todos modos es de agradecer. Otras, en cambio, relaja pormenores en obras religiosas que de sobra sabría reconocer, como si tuviera problemas de identificación iconográfica en ejemplos del estilo de: "una pintura con un Nuestro Señor y una Nuestra Señora", dejándonos desgraciadamente «a mitades". En inventario de bienes de Domingo Calbo, vecino de Cepeda y año 1694, que por su interés transcribimos, el tasador identifica sin rodeos en una tipología tan deslizante como la de las santas penitentes, a María Egipcíaca, a quien no confunde con Magdalena, mucho más popular y divulgada, pero no logra superar la prueba del santo compañero de cuadro. En este caso deducimos que actuó sin ayuda del enunciado", donde no se hubiera omitido ninguno de los dos nombres: "quadro con Santa María Giciaca y otro santo. Siete láminas guarnecidas con oropel. Cuadro de la Cena. Otro país del bautismo. Otro de la Soledad, otro de la Samaritana y Nuestra Señora. Una N. ${ }^{a}$ S. $^{a}$ de Franzian ${ }^{3}$.

\section{El cuadro}

Un segundo y muy abundante número de obras pintadas o con otras técnicas, aparece inventariado en esa documentación serrana bajo la genérica denominación de cuadro. Esta voz, en contraste con la que se describe como pintura o de pincel, parece acoger a las piezas de calidad inferior, menor tamaño y siempre un precio más asequible. Son producciones de taller, casi en serie, con un final en ocasiones mecánico y carácter divulgativo. Proceden de obradores con profesionales segundones que dan salida a su obra en las grandes ciudades con calles especializadas en este tipo de tiendas y son también producto de aquellos monasterios que gozaban de advocaciones muy veneradas. Era un arte predominantemente religioso, de iconografía repetitiva, a todos los tamaños y a merced del devoto, y se conocía en la calle como «de alcoban.

Las variantes del soporte no se reducen ahora al lienzo o a la tabla, se dan ejemplos, además, de pintura y estampación, en estopa, angeo, sobre cristal, bronce, cobre, hojadelata, nácar, vitelo, papel, seda, etc.

\footnotetext{
3 Cepeda, AHPS, Prot. 5994, f. $104 \mathrm{v}$.
} 
Entre los siglos XVII y XIX son tres las ciudades documentadas como focos de exportación de estos cuadros, que supondrían para el comprador de entonces algo parecido a lo que entendemos hoy como pieza pret-à-porter: Valencia, Sevilla y Valladolid. Esta última por cercanía con las comarcas que estudiamos debió resultar más familiar y suponemos tendría allí mayor incidencia. Parece que los cuadros los vendían tenderos en la calle de Santiago y se conocían como de Valladolid, ,pintura de Valladolid, ,de la fábrica de Valladolid, ,hechura de Valladolid" o ede la calle de Santiago de Valladolid". Sabemos que algunos eran pequeños y tenidos ya en el siglo xvII por .antiguos" o algo antiguos". Su precio oscila siempre entre dos y cuatro reales. Muchos de ellos se especifican como de Nuestra Señora de la Soledad; posiblemente se trataba de las Angustias, de tanta devoción en esa ciudad y divulgada por un grabado de Roelas en la temprana fecha de 1603.

\section{El lienzo pintado y el paño de pintura}

Un último y curioso subgénero dentro de la pintura, queda registrado en los documentos como "lienzo pintado", "paño de pintura" y* sábana de pintura. Pienso que nos hallamos ante una modalidad que nace y evoluciona dentro de lo que se conoce hoy como popular. Espontáneo recurso de imaginación que suele carecer de elementos asociados a un estatus alto, como son el marco y el bastidor. "El paño de pinturawiene a contraponerse y suplir al país, colgándose directamente en la pared. Goza de mayor libertad con posibilidades múltiples: sirviendo, si conviene, en el exterior para momentos de arquitecturas efímeras y como guarnición en ventanas y altares domésticos a las puertas de las casas. Todavía sigue hoy utilizándose en la Sierra de Francia, donde se conoce bajo la voz antigua de "paño de pulir", si bien derivado por su temática y técnicas hacia el bordado tradicional ${ }^{4}$.

De los cuatro inventarios que documentamos solo uno nos viene a desvelar el tema: "Nuestro Señor y Nuestra Señora pintados en una sábana". No están estos ejemplos lejos de las grandes piezas de angés o angeo, prácticamente desaparecidas y que servían como guardapolvos a los retablos, o de telón de fondo en el Monumento del Jueves Santo, con arquitectura de trampantojo, emblemas o escenas de la Pasión con una técnica efectista y simplificada. En este sentido cabría interpretar el documento donde se cita "un paño de pintura de lacena", si no hubiera costumbre de guarnecer con paños, arcas, frontaleras de cama, vasares y alacenas, que es el sentido que sin más debería tener aquí. Curiosamente, de ninguno de esos paños se hace

- Ver en A. CEA, Guía de la Artesanía en Salamanca... (Madrid: M. de Industria y Energía, 1985) lo referente al bordado, pp. 178-184. 
tasación. Queda bien clara con estos dos ejemplos y también con otro más donde dice: eun quadro de la Cena", la distinción entre cuadro y paño.

\section{LA ICONOGRAFIA}

Distribuimos los temas iconógraficos en dos apartados fundamentales. El primero acoge las devociones religiosas, el otro las aficiones, no menos devotas por profanas.

\section{TABLA DE CONTENIDOS}

\section{LO SAGRADO}

I. ESCENAS DEL ANTIGUO TESTAMENTO

II. TEMAS DEL NUEVO TESTAMENTO

- Vida de Cristo

- Vida de María

- Personajes aislados

- Detalles sobre una persona

- La Sgda. Familia, sacra conversazione, simplificación del Trinubium o Parentela de María

- Niños Jesús

- Crucifijos y Cruces

- Advocaciones locales de Cristo

- El Sacramento

III. ADVOCACIONES MARIANAS

- De carácter general

- Particulares o topográficas

- De N. ${ }^{a}{ }^{2}{ }^{a} \sin$ especificar

- Las medidas

IV. SANTORAL

- Agrupados

- Geminados

- Aislados

- sólo con atributos

- en escena o pasajes de sus vidas

V. TEMAS DEL ALMA O POSTRIMERIAS

\section{LO PREDOMINANTEMENTE Profano}

VI. EL PAÍS

- El país de caza 
VII. EL BODEGÓN

VIII. TEMAS MITOLÓGICOS, ALEGORÍAS Y EMBLEMAS

IX. EL RETRATO

X. PERSONAJES HISTÓRICOS

XI. OTROS PERSONAJES Y TEMAS

XII. LA DENOMINACIÓN DE PROCEDENCIA DESPLAZA EL TEMA DE LA OBRA

- Obra de Francia

- Obra de Sevilla

- Obra de Valencia

- Obra de Valladolid

- Escaparates y obra de monjas

XIII. TEMAS SIN IDENTIFICAR

\section{SIGLO XVII ${ }^{5}$}

I. Escenas del ANtiguo Testamento (22 obras)

Las Sibilas (21 obras de 1675-1690)

- Diez quadros pequeños, pintadas las Sibilas, 70 reales. 1675. San Martín. Inventario (Prot 6190, f. 97) ${ }^{6}$

- Onze sibilas. 1690. Cepeda. Inv. Lcd. ${ }^{\circ}$ Manuel Pérez de Torivio, pbr. ${ }^{\circ}$ (Prot. 5993, ff. 138-157v)

La Escala de Jacob (una obra, 1686)

- más otro paño de la escala de Jacob. [junto al paño de la pintura ede lazenan]. 1686. Sequeros. Inv. Francisco Rodríguez. (Prot. 6230, f. 80)

5 Todos los documentos que estudiamos pertenecen al Archivo $\mathrm{Hc} .^{\circ}$ Provincial de Salamanca (AHPS) y Sección de Protocolos. Para facilitar la lectura no desglosamos en nota a pie las signaturas, sino que van después de cada documento. Los precios de las tasaciones, que a veces se describen en letra, quedan unificados en cifra.

6 Marco VARrón, según texto del Autoridades, dice ahaber sido diez las famosas: Pérsica, Lybica, Délphica, Cimmeria, Erithrea - la más desacada según los santos Agustín e Isidoro-, Samia, Cumana o Cumea, Elespontia, Phrygia y Tiburnina. La colección de Cepeda aumenta en uno el número de ellas, presentadas en serie en pinturas independientes. 


\section{Temas del Nuevo Testamento ( 77 obras)}

VIDA DE CRISTO [12]

El Bautismo [(1), 1694]

- otro país del Bautismo. 1694. Cepeda, inv. de Domingo Calbo (Prot. 5994 , f. $104 \mathrm{v})$

Bodas de Caná [(1), 1684]

- la cena de las bodas de Caná. 1684. Cepeda, inv. de Francisca Sánchez (Prot. 5991, ff. 127 y ss. )

La Samaritana [(1), 1694]

- otro de la Samaritana y $N^{a}$ Señora. 1694. Cepeda, inv. de Domingo Calbo (Prot. 5994, ff. 104v)

Última Cena [(4), 1682-1694]

- otra lláminal con el misterio de la Cena. 1682. Cepeda, inv. de Ana Domínguez (Prot. 5991, ff. 139 y ss. )

- un paño de pintura de lazena. 1686. Sequeros, inv. Francisco Rodríguez (Prot. 6230, f. 80 )

- otro [quadro] de la Cena. 1690. San Martín. Inventario (Prot. 6192, f. 119$)^{8}$

- Cuadro de la Cena. 1694. Cepeda, inv. de Domingo Calbo. (Prot. 5994, f. $104 \mathrm{v})$

Calvario [(1), 1649]

- lienço con Santo Xt." con $N^{a}$ S. $^{a}$ y San Juan. 1649. Cepeda. Inventario (Prot. 5982, f. 216v) ${ }^{9}$

Descendimiento $[(3), 1648-1690]$

- otro quadro del Descendimiento de la cmiz, cinco $r$ s. 1648. Cepeda,

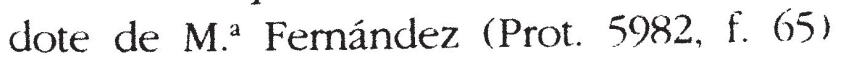

- lienço pintado del descendimiento con otros santos. 1649. Cepeda. Inventario (Prot. 5982, f. 216v)

- Debe leerse Nuestro Señor. a menos que el lienzo presentara dos temas aislados entre sí.

8 Lo que hoy conocemos como bodas de Caná aparece en el inventario de 1684 pormenorizado a la hora de la cena - tema que en el Renacimiento y Barroco fue excusa para el bodegón y el intrusismo de una instantánea cortesana, como el tema de Cristo en casa de Marta y María- La última Cena, en cambio, se describe en los cuatro ejemplos serranos no como la última.

9 Como veremos, S. Juan Evangelista o aparece formando parte del Calvario con N. ${ }^{a} S^{2}$ o con Magdalena camino de él. El verdaderamente arraigado y popular San Juan es el Bautista. 
- [...] otro del Descendimiento. 1690. San Martín. Inventario (Prot. 6192, f. 119)

Noli me tangere [(1), 1651]

- estampa de la adoración de la magdalena quando se le apareció el Señor. 1651. San Esteban, testamento de Beatriz de Linares (Prot. 6187, f. 78v) ${ }^{10}$

\section{VidA de Marta [8]}

Anunciación [(2), 1669-1694]

- lienço pintado en él la Anunciación de $N^{a} S^{a}$ y una cruz de vedrieras en ella. 1669. Cepeda, inv. de Pedro Felipe de Andrés (Prot. 5987, ff. 95-96v)

- otro [quadro] de la Encarnación. 1694. San Martín, inv. Lcd. ${ }^{\circ}$ Francisco

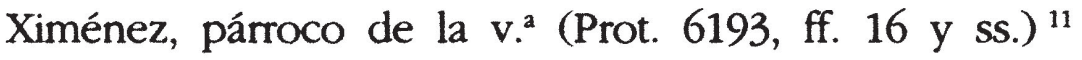

Visitación [(1), 1649]

- sábana pintada con la Bisitación. 1649. Cepeda. Inventario (Prot. 5982, ff. 66 y ss.)

Presentación [(1), 1690]

- lámina enjadelata de la presentación en el templo. 1690. Cepeda, inv. Lcd. ${ }^{\circ}$ Manuel Pérez de Torivio, Pbr. ${ }^{\circ}$ (Prot. 5993, f. 146)

El Niño Perdido [(1), 1648]

- quadro sin guarnecer de $N^{a} S^{a}$ y $S$. Joseph, de la entrada de Jerusalén, 16 rs. 1648. Cepeda, dote de M. ${ }^{2}$ Fernández (Prot. 5982, f. 65) ${ }^{12}$

Asunción [(1), 1660]

- un quadro de una Ntr. ${ }^{a} .^{a}$ de la Asunción. 1660. Cepeda, inv. Francisco Felipe (Prot. 5985, f. 60)

10 Se trata sin duda de la iconografía conocida en Arte como Noli me tangere. Extraña que se nos describa aquí en paráfrasis, pues esa fórmula debía ser sobradamente conocida y así la recoge Correas en la época de este inventario.

1 Comenzaba ya a usarse este título de Anunciación, que es el que hoy pervive, conjuntamente con el renacentista de la Encarnación, desplazando al de Salutación que se empleaba hasta finales del siglo XV y al de la Embaxada del Angel, más utilizado en los documentos de esta comarca a lo largo del siglo XVI. La cruz de vidrieras que se describe con este lienzo debe referir a la costumbre de clavar medallas o relicarios en los marcos de los cuadros e incluso sobre la misma pintura. Así lo hemos llegado a ver en el coro alto del monasterio de Franciscas del Zarzoso.

12 Si nos atenemos a lo que hoy se entiende por Entrada en Jerusalén sobraría la figura de San José - muerto ya antes de la Pasión- y no parece lapsus del que está describiendo la dote. $O$ nos hallamos ante una iconografia aberrante, lo que debemos descartar de todo punto, o se trata, como creemos, de la búsqueda del Niño perdido y hallado por sus padres en el Templo, entre los doctores. 
Coronación [(2), 1649-1690]

- quadro de pader [sic por pared] con la Cononación de Maria. 1649. Cepeda. Inventario (Prot. 5982, f. 216v)

- Coronación de $N^{a} .^{a} .^{a}$ en cuadro. 1690. Cepeda, inv. Lcd. ${ }^{\circ}$ Manuel Pérez de Torivio, Pbr. $^{\circ}$ (Prot. 5993, f. 146)

\section{Personanes aislados [8]}

Buen Pastor [(2), 1684-1699]

- quadro del Buen Pastor. 1684. Cepeda, inv. Francisca Sánchez (Prot. 5991, ff. 127 y ss.)

- quadro del Buen Pastor. 1699. San Martín, inv. Lcd. ${ }^{\circ}$ pbr. ${ }^{\circ}$ Gonzalo López de Sanz (Prot. 6194, f. 211v)

Ecce Homo [(6), 1658-1686]

- quadro imaxen de un eccebomo, $500 \mathrm{mrs}$. 1658. Cepeda, inv. Francisco García y María Velasco (Prot. 5984, f. 95v)

- quadro de Eccehomo. 1659. Sequeros, inv. Catalina Garzía (Prot. 6235, ff. 19 y ss.) ${ }^{13}$

- dos quadritos pequeños, ecehomo y $N^{a} .^{a} .^{a}$ 1673. San Martín, inv. Francisco López, noble (Prot. 6190, f. 15)

- quadro eccebomo, 10 rs. 1675. San Martín. Inventario (Prot. 6190, f. 97)

- al altar del Niño Jesús 100 rs. y un quadro de un ecceomo. 1686.

Alberca. Testamento (Prot. 6143, f. 120)

\section{Detaules SOBRe UNA PERSONA [9]}

Verónica [(6), 1647-1679]

- Santa Verónica de guadamaci. 1647. San Martín. Inventario (Prot. 6188, f. 160)

f. 216v)

- quadro de una barónica. 1649. Cepeda. Inventario (Prot. 5982,

- una echura de una berónica. 1657. Sequeros, inv. María Gutiérrez (Prot. 6225, ff. 48 y ss. )

- otro [quadrol de una berónica. 1658. Cepeda, inv. M.. González, Vd." (Prot. 5984, f. 65)

- estampa de la Berónica. 1668. San Martín. Inventario (Prot. 6189, f. 12v)

13 Debían ser estos cuadros de los denominados de devoción-, en los que el personaje, en este caso Cristo, queda en solitario, desgajado del resto de la escena que le da nombre, para que nada pueda distraer al orante y esto, tanto en las obras de spintura fina- como en las que se vendían casi en serie. Al mismo tiempo los rasgos de dolor y las señales de tortura se magnifican para mover a compasión. Vuelven, como en la Edad Media, a eliminarse los fondos que quedan ahora en colores oscuros o, a lo más, con nubes. 
- lquadro del La Verónica. 1679. San Martín. Inventario (Prot. 6191, f. 25)

El Redentor [(3), 1679]

- tres quadros del Redemptor. 1679. San Martín (Ibid.) ${ }^{14}$

\section{La Sagrada fammia [8]}

Nuestra Señora y San José [(6), 1649-1690]

- tres quadros de $N^{a} S^{a} y$ San Josephe. 1649. Cepeda. Inventario (Prot. 5982, ff. 66 y ss.)

- estampa en papel de $N^{a} S^{a}{ }^{a}$ y San Joseph. 1674. San Martín. Inventario (Prot. 6189, ff. 195 y ss.)

- otro de San Joseph y $N^{a} S^{a}$, quadro de $S$. Joseph y N. ${ }^{a}{ }^{a}{ }^{a}$ 1690. San Martín. Inventario (Prot. 6192, f. 119)
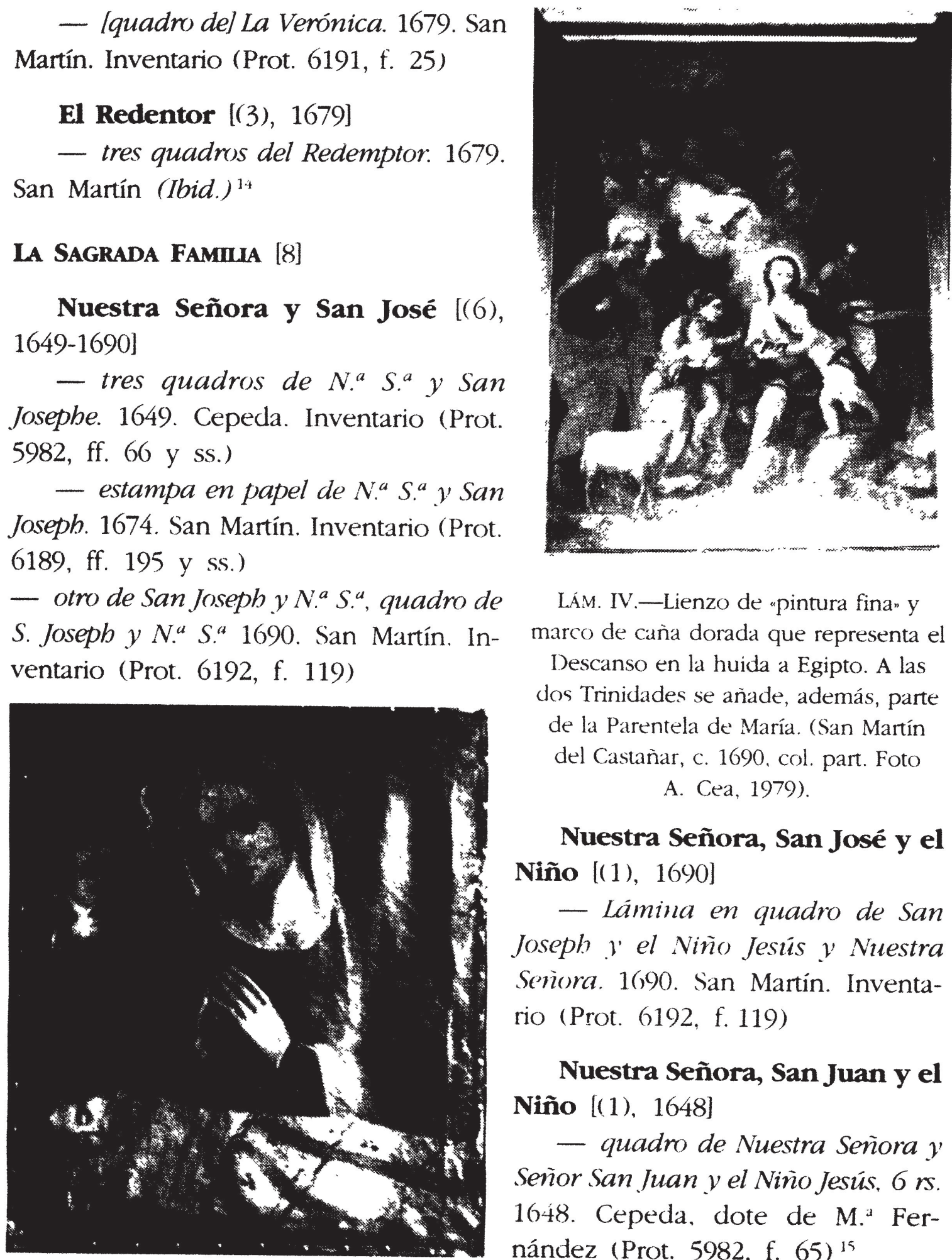

LÁM. IV.-Lienzo de "pintura fina" y marco de caña dorada que representa el Descanso en la huida a Egipto. A las dos Trinidades se añade, además, parte de la Parentela de María. (San Martín del Castañar, c. 1690. col. part. Foto A. Cea, 1979).

Nuestra Señora, San José y el Niño [(1), 1690]

- Lámina en quadro de San Joseph y' el Niño Jesüs y Nuestra Seniora. 1690. San Martín. Inventario (Prot. 6192, f. 119)

Nuestra Señora, San Juan y el Niño [(1), 1648]

- quadro de Nuestra Señora y Señor San Juan y el Niño Jesús, $6 r$ s. 1648. Cepeda, dote de M.a Fernández (Prot. 5982, f. 65) ${ }^{15}$

LÁM. V.-El Sueño de la Pasión o N. ${ }^{a}$ S. $^{a}$ con el Niño y San Juanito. (Óleo sobre lienzo, s. AVI, "obra de Valladolid". La Alberca, col. part. Foto M. ${ }^{a}$ Jesús del Amo, 1993).

14 ¿Puede interpretarse como un Salvador bendiciendo y con orbe, o como vencedor de la muerte con la cruz y pisando la calavera?

15 Creemos que en ninguno de estos ejemplos se da en toda complicación la escena de la Parentela o el trinubium de Santa Ana, sino la que llamamos Trinidad terrena, a lo 
Niño Jesús [(9), 1649-1690]

- echura de un Niño Jesús. 1649. Cepeda. Inventario (Prot. 5982, ff. 66 y ss.)

- echura de un Niño Jesús. 1649. Cepeda. Inventario (Prot. 5982, f. 216v)

- bechura de Niño Jesús con su camisita. 1658. Cepeda, inv. María González, Vd.² (Prot. 5984, f. 65)

- quadro sin marco de Jesús Niño. 1673. San Martín, inv. Francisco López (Prot. 6190, ff. 12 y ss.)

- echura de Niño Jesús de mediana estatura con su caxa. 1680. Cepeda, inv. Francisca Sánchez, Vd. ${ }^{2}$ (Prot. 5990, f. 175v)

- Niño Jesús bestido con su roseta de listón colorado y negro. 1682. Cepeda, inv. Ana Domínguez (Prot. 5991, ff. 139 y ss.)

- una echura de Niño Jesús. 1686. Sequeros, inv. M." Rodríguez y Figueroa (Prot. 6230, f. 19)

- una echura de un Niño Jesús. 1686. Sequeros, inv. Francisco Rodríguez (Prot. 6230, f. 80)

- Niño Jesús con su peana y camisa y baquerito. 1690. Cepeda, inv. Lcd." Manuel Pérez de Torivio, Pbr. ${ }^{\circ}$ (Prot. 5993, f. 146) ${ }^{16}$

Crucifijos y cruces [(21), 1649-1697]

- Cruz con un poco de tafetán común. 1649. Cepeda. Inventario (Prot. 5982, f. 216v)

- quadro de una imaxen de un Santo Xt. y San Francisco, $800 \mathrm{mrs}$. 1657. Cepeda, inv. Francisco Garzía y María Velasco (Prot. 5984, f. 95v) ${ }^{17}$

- Un Santo Xt..$^{\circ}$ de barro. Una echura de St. ${ }^{\circ} X t^{\circ}$ con su cruz sobredorado pequeño. 1663. Sequeros, inv. Catalina Sánchez (Prot. 6225, f. 25)

- una echura de un $S t^{\circ} \mathrm{Xt}^{\circ}$ 1665. Sequeros, inv. Catalina Gutiérrez (Prot. 6226, f. 44v)

- estampa de un cruzifijo. 1668. San Martín. Inventario (Prot. 6189, f. $12 v$ )

más con la figura del Bautista Niño, la Sagrada Familia simplificada o sacra conversazione. En cuanto a los documentos en que se describe solo Nuestra Señora, no sabemos si se incluiría el Niño. Si no son abstraídos como dos figuras de devoción podría pensarse en cualquiera de las escenas en que aparecen José y María como protagonistas: Dudas de San José, Sueño de San José, Petición de Posada, Huida o Descanso en la Huida a Egipto, Niño Perdido, o Taller de Nazaret, descartando la Natividad, Epifanía, Purificación y Circuncisión, y desde luego, la Muerte de San José.

16 Son los que hoy se conocen en la Alberca como Niños Batuecos y aparecen como anticipados Salvadores si están de pie, si sentados o dormidos, premonitores de la Pasión, portando a veces los atributos o improperios.

17 Debe tratarse del abrazo místico entre el Crucificado y el Santo de Asís. 
- quadro [...] de Ntr..$^{\circ}$ Redentor Jxt. crucificado y La Madalena y St. Domingo. 1672. San Martín. Inventario (Prot. 6190, f. 44) ${ }^{18}$

- echura de Xt. ${ }^{\circ}$ de bronce con su peana [... imagen de Crucifixo en un quadro pequeño con su marco. 1674. San Martín. Inventario (Prot. 6189, ff. 195 y ss.)

- Una estampa de papel con un pañito encima del Santo Xt. más un Santo Xt..$^{\circ}$ de bronce. 1678. Sequeros, inv. de María Ernández (Prot. 6228, f. 92$)^{19}$

- una echura de un Santo Xt. con el brazo. 1684. Sequeros. Inventario (Prot. 6229, f. 49v) ${ }^{20}$

- una echura de Santo Xt. ${ }^{\circ}$ 1686. Sequeros, inv. Francisco Rodríguez (Prot. 6230, f. 80)

- un Xt. viexo. 1689. Sequeros, inv. Catalina Garzía (Prot. 6234, f. 75)

- Lámina con una ymagen de un Cristo bordado con unas cintas alrededor. 1690. Cepeda, inv. Lcd. ${ }^{\circ}$ Manuel Pérez de Torivio, pbr. ${ }^{\circ}$ (Prot. 5993, f. 146)

- Una estampa de lienço con un Santo Xt. ${ }^{\circ} 1691$. Cepeda. Inventario (Prot. 5993, ff. 17-17v)

- el Crucifixo que tengo de pinzel. 1693. Sequeros, test. ${ }^{\circ}$ Lcd. ${ }^{\circ}$ Antonio Hernández Robles (Prot. 6232, f. 139)

- una echura de un crucifijo en una Cruz, fáltale un brazo al Cruzifijo. 1694. Sequeros, inv. Ynés Díez Cordera (Prot. 6263, f. 222v)

- una Imaxen del St..$^{\circ} t^{\circ}$ 1697. Sequeros, inv. Juan Berrocal (Prot. 6234, f. 132)

- dos paños labrados con seda colorada y azul y una cruz en medio. 1697. Sequeros, inv. M. ${ }^{2}$ Rodríguez Figueroa (Prot. 6234, f. 188) ${ }^{21}$

18 Probablemente sea un cuadro de composición de lugar en el que Magdalena y sobre todo Santo Domingo, como eintruso devoton, suplantan a la Virgen y al Evangelista formando Calvario.

19 Parece un ejemplo de revestimiento de la imagen modificando el original, tan del gusto de la época. Pero no queda claro si el pañito- debe interpretarse como perizonium o faldellin o, lo que parece más probable, fuera una toballa que colgara de los brazos de la cruz.

20 Creemos estar ante una pieza ipopularizada? de la ya para esta época rara iconografía del Descendimiento, cuyos ejemplos teatralizantes más representativos son quizá el de San Juan de las Abadesas y el burgalés de las Huelgas. Posteriormente se vinieron reintrerpretando como "Cristos testigos", si recordamos el becqueriano de la Vega en Toledo, y debieron recibir la denominación sin más de .Cristos con el brazo.

21 A pesar de la escueta descripción parecen estos dos paños labrados claro exponente, y coinciden en el tiempo (1697), de la fase del bordado en la Sierra de Francia que llamamos de sobrepuesto. Ver en A. CEA, op. cit., p. 182. 


\section{Advocaciones locales de CRISto [2]}

Burgos [(2), 1690-1694]

- Cuadrito en papel de Xt. de Burgos. 1690. Cepeda, inv. Lcd. Manuel Pérez de Toribio, pbr. ${ }^{\circ}$ (Prot. 5993, f. 146)

- otro [quadro] del St. $.^{\circ} t^{\circ} .^{\circ}$ de Burgos. 1694. San Martín, inv. Isabel Sánchez (Prot. 6193, f. 39) ${ }^{22}$

\section{ADVOCACIONES MARIANAS [49]}

DE carácter geñRal [15]

\section{Angustias [(1), 1678]}

- quadrito de la bingen de las Angustias. 1678. Sequeros, inv. María Ernández (Prot. 6228, f. 92)

Piedad [(2), 1690-1694]

- otro de $N^{a} S^{a}$ de la Piedad. 1690. San Martín. Inventario (Prot. 6192, f. 119)

- quadro de . $^{a}$ S. $^{a}$ de la Piedad. 1694. San Martín, inv. Isavel Sanz (Prot. 6193, f. 39)

Soledad [(3), 1665-1695]

- una pintura de la imaxen de la soledad. 1665. Sequeros, inv. Catalina Gutiérrez (Prot. 6226, f. 44v)

- otro [quadro de la Soledad]. 1694. San Martín, inv. Lcd. ${ }^{\circ}$ Francisco Ximénez, pbr. (Prot. 6193, ff. 16 y ss.)

- un quadro de N..$^{a}{ }^{a}$ de la Soledad. 1695. Sequeros, inv. María Mathías (Prot. 6233, f. 116) ${ }^{23}$

Carmen [(3), 1671-1680]

- quadro de bara y media de largo y tres quartas de ancho, pintura de $N^{a}$ S. $^{a}$ del Carmen, sin marco, casi nuevo. 1671. San Martín, inv. Vd." de Francisco Humado (Prot. 6189, f. 10)

22 Es curioso que las dos únicas piezas-testigo de Cristos locales en este siglo sean del de Burgos, sin duda uno de los más difundidos, entre otras cosas, por su mortosa configuración. Pese a todo, sólo vuelve a documentarse en la Sierra de Francia otras dos veces en el siglo XviII (1736 y 1762) ahora como joya, aunque en las mismas localidades de Cepeda y San Martín del Castañar. Fue muy conocida la versión de Juan Palomino y José Doblado (ver en RDTP, XIV (1990) el artículo de Concepción ALARCON sobre tla Iconografía religiosa en el siglo XVIIr, en especial las pp. 250 y 251).

23 Es probable que bajo la triple denominación: Angustias, Piedad y Soledad, se estuviera aludiendo a una sola iconografía - sobre todo si viene de la fábrica de Valladolid- a las que en el siglo Xvin se añadirá, por si fuera poco, la de los Dolores. Había pasado con mucho el tiempo en que el pueblo aquilataba estas distintas secuencias de la compassio Mariae. 


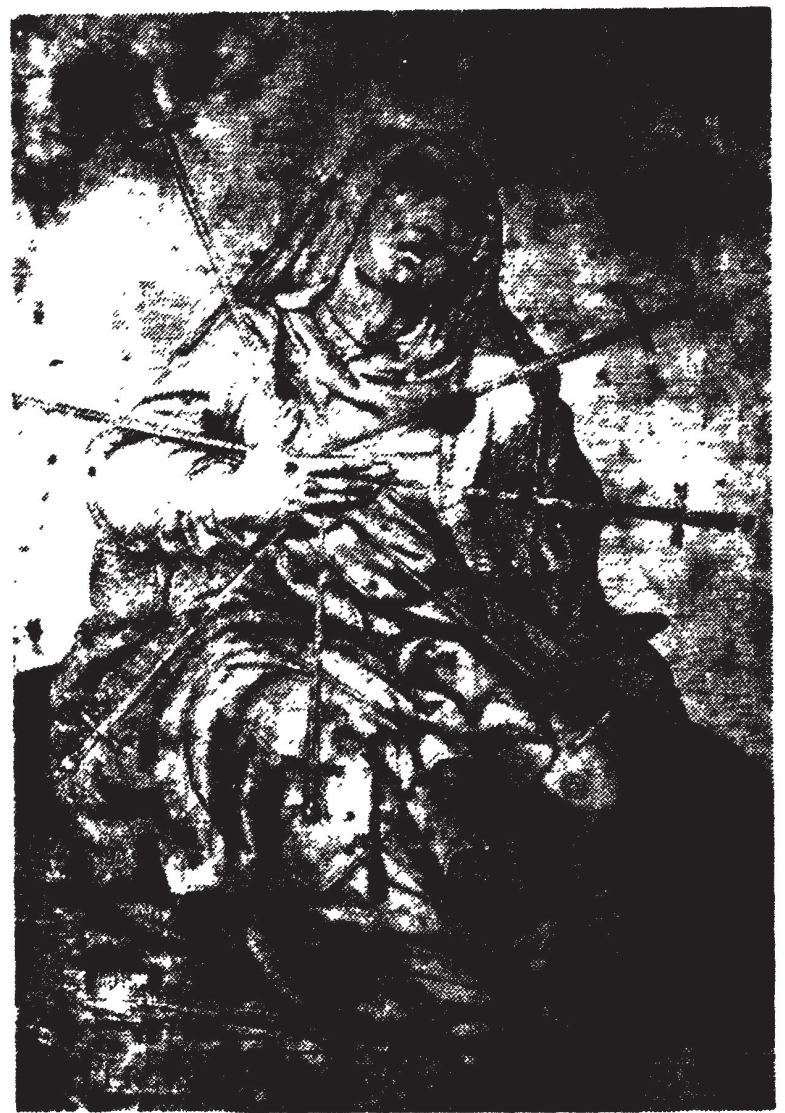

LÁM. VI.-Plancha para el grabado de la Quinta Angustia, de Juni, por Roelas, año 1603. Fue una de las devociones más divulgadas como "obra de Valladolid. (Col. part.)
- otro del Carmen [...] 1679. San Martín. Inventario (Prot. 6191, f. 25)

- un escudo de armas de $N^{a}$ S. ${ }^{a}$ del Carmen. 1680. Cepeda, inv. Francisca Sánchez, Vd. ${ }^{a}$ (Prot. 5993, f. $175 v$ )

Concepción [(4), 1649-1699]

- cuadro de la Concepción de $N^{a} S^{a}$ con un Niño Jesús en sus brazos. 1649 . Cepeda. Inventario (Prot. 5982, f. 216v)

- quadro con su marco, pintada la Concepción. 1673. San Martín, inv. Francisco López (Prot. 6190, ff. 12 y ss.)

- Estampa de la Concepción. 1690. Cepeda, inv. Lcd. ${ }^{\circ}$ Manuel Pérez de Toribio, pbr. ${ }^{\circ}$ (Prot. 5993, f. 146)

- quadro de $N^{a}$ S. $^{a}$ Concezión. 1699. San Martín, inv. Lcd. ${ }^{\circ}$ pbr. ${ }^{\circ}$ Gonzalo López de Sanz (Prot. 6194, f. $211 \mathrm{v})^{24}$

Reina de los Ángeles [(1), 1673]

- Lámina efigie de la Reyna de los Angeles, guarnecido de bilo de oro y plata y sedas de diferentes colores. 1673. San Martín, inv. Francisco López (Prot. 6190 , ff. 12 y ss.) ${ }^{25}$

24 En rigor esta advocación debiera contemplarse en el apartado de la Vida de María como su primera aparición en escena, no sabemos si identificada con el Abrazo en la Puerta Dorada. Arrastrando secuelas iconográficas cuyos primeros antecedentes serían los de la Mujer Apocalíptica y después de pasar por la panoplia de símbolos en la Tota Pulchra, se viene a desembocar en la Concepción, Purísima o Inmaculada. Apoteosis descontextualizada en lo formal sobre lo que debió ser la Concepción virginal de M. ${ }^{2}$. En el primer ejemplo (Cepeda 1649) la representación con Niño, seguramente alanceando la cabeza del dragón o serpiente, referiría a la que denominamos Inmaculada franciscana.

25 Esta lámina se documenta junto a otras dos, todas pequeñas y redondas, posiblemente relicarios. Quizá sería arriesgado suponer una lectura literal en esta advocación de la Virgen como Reina de los ángeles. Por estos mismos años era invocada así María en los encabezamientos de testamentos, y también como Reina de cielos y tierra, con la sola intención de engrandecer su nombre y pareciendo poco las invocaciones antiguas como Santa María o Nuestra Señora. 
Rosario [(1), 1649]

- quadro del Rosario. 1649. Cepeda. Inventario (Prot. 5982, f. 216v)

Parmculares o Topográficas [8]

Atocha [(1), 1690] $142 v-145)$

Caridad [(1), 1690]

- otro [quadro] de $N^{a}$ S. $^{a}$ de la Caridad. 1690. San Martín. Inventario (Prot. 6192, f. 119) ${ }^{26}$

Francia [(1), 1694]

- Una N. ${ }^{a}$ S. ${ }^{a}$ de Franzia. 1694. Cepeda, inv. Domingo Calvo (Prot. 5994, f. $104 \mathrm{v})$

Loreto $[(1), 1679]$

- otro del Carmen y Loreto. 1679. San Martín. Inventario (Prot. 6191, f. 25)

Monte Cedrón [(1), 1674]

- estampa en papel de $N^{a}{ }^{a}{ }^{a}$ del Monte Cedrón. 1674. San Martín. Inventario (Prot. 6189, ff. 195 y ss.)

Pópulo [(2), 1651-1673]

- Lámina de $N^{a}{ }^{\text {S }}{ }^{a}$ del Pópulo. 1651. Cepeda, inv. Antonio Corral (Prot. 5983, f. 290)

- Lámina efigie de $N^{a}$ S. $^{a}$ del Pópulo con su marco e diez y seis nichos en que bay reliquias de diferentes santos. 1673. San Martín, inv. Francisco López (Prot. 6190, ff. 12 y ss.) ${ }^{27}$

Río [(1), 1671]

- quadro de cinco quartas en largo y bara de ancbo, pintura de $N^{a}$ S. $^{a}$ del Río. 1671. San Martín, inv. Vd. ${ }^{a}$ de Francisco Mercado (Prot. 6189, f. 10)

De Nuestra Señora sin especificar [(23), 1642-1698]

- una sábana con Nuestro Señor y Nt. ${ }^{a}$ Señora. It. Quadro de la Bendita Vergine María, quadro pequeño de $N^{a}{ }^{a}{ }^{a}$ 1642. Cepeda, inv. Juan Fernández, Maestro (Prot. 5891, f. 17v)

26 Debe tratarse seguramente de la venerada con este título en Illescas o Caridad por antonomasia y matriz de las demás homónimas. En el ejemplo que documentamos un siglo después (Sequeros, 1704) aparecerá ya sin más como N." S.* de lllescas, oscureciendo el topónimo a la advocación original.

27 Estuvo muy extendida la devoción en España - falta en pocas catedrales-a este icono romano que se representa de busto y dentro del esquema de las clasificadas como bodigitrias, cuyos paralelismos de fondo y forma parecen transferidos hoy a la devoción conocida como del Perpetuo Socorro. 
- Una caxa de madera con una $N^{a} S^{a}$ It un quadro de $N^{a} S^{a} 1651$. Cepeda, inv. Antonio Corral (Prot. 5983, f. 290)

- quadro de la imaxen de $N^{a} S^{a} .^{a}, 500 \mathrm{mrs}$. 1657. Cepeda, inv. Franc. Garzía y M. ${ }^{2}$ Velasco (Prot. 5984, f. 95v)

- quadro pequeño con $N^{a}{ }^{a}{ }^{a}$ y el Niño Jesús. 1659. Cepeda, inv. D. ${ }^{2}$ M. $^{2}$ Gutiérrez, muxer de Jerónimo de la Alverca (Prot. 5985, f. 9)

- quadro de cinco quartas de lango y bara de ancho, pintura de $N^{a} S^{a}{ }^{a}$ 1671. San Martín, inv. Vd. ${ }^{a}$ de Francisco del Mercado y mujer de Domingo Hidalgo (Prot. 6189, f. 10)

- dos quadritos [uno del N. ${ }^{a} S^{a}{ }^{a}$ 1673. San Martín, inv. Francisco López, noble (Prot. 6190, f. 15)

- Imagen de $N^{a}{ }^{a} .^{a}$ con el Niño Jesús al pecho, con su marco. 1674. San Martín. Inventario (Prot. 6189, ff. 195 y ss.)

- quadro de N. ${ }^{a}$ S. $^{a}$ 1675. Cepeda, inv. Domingo Rodríguez (Prot. 5989, f. 102)

- quadro de N. ${ }^{a} S^{a}{ }^{a}$ 1678. Cepeda, inv. M.. Sánchez, Vd. ${ }^{a}$ (Prot. 5989, f. 168)

- otros dos Iquadrosl de N..$^{a}{ }^{a}$ 1679. San Martín. Inventario (Prot. 6191, f. 25)

- quadro grande de N. ${ }^{a} S^{a} y$ dos pequeños. 1680. Cepeda, inv. Francisca Sánchez, Vd. ${ }^{2}$ (Prot. 5990, f. 175v)

- bitela de $N^{a}{ }^{a} .^{a}$ con flores encarnadas adomando alrededor. 1682. Cepeda, inv. Ana Domínguez (Prot. 5991, ff. 139 y ss.) ${ }^{28}$

- Una N. ${ }^{a}{ }^{a}$ con unas puertitas (parece caxa). 1684. Cepeda, inv. Antonio Corral (Prot. 5991, ff. 127 y ss.)

- imagen de $N^{a}{ }^{a} .^{a}$ con su vestido. Un quadro de $N^{a} S^{a}{ }^{a}$. Lámina de $N^{a}$ $S^{a}{ }^{a}$. Lámina de $N^{a} S^{a}$ bordada de flores alrededor colorado y blanco. 1690. Cepeda, inv. Lcd. ${ }^{\circ}$ Manuel Pérez de Torivio, pbr. ${ }^{\circ}$ (Prot. 5993, f. 146)

- quadro de la ymagen de la Vingen con sus cortinas. 1698. Cepeda. Inventario (Prot. 5995, f. 141v) ${ }^{29}$

MEDIDAS [(3), 1685-1690]

De Francia [(1), 1690]

- una medida de Francia. 1690. Cepeda. Inventario (Prot. 5993, ff. 142v-145)

Con Agnusdei [(1), 1685]

- medida con un Anus Dei de echura de oro. 1685. Sequeros, inv. Francisco Cordero de las Matas (Prot. 6230, ff. 66 y ss.)

28 Parece por sus características un cuadro-escaparate de los conocidos como de mano de monxas".

29 No sabemos si interpretar literalmente las cortinas como guardapolvo del cuadro, solo desvelado en ocasiones puntuales, o si refiere por el contrario, a los tafetanes pintados a manera de pabellón, enmarcando la imagen. 
Sin especificar [(1), 1690]

- una medida açul grande. 1690. Cepeda. Inventario (Prot. 5993, ff. $142 v-145)^{30}$

IV. SANTORAL [81]

SANTAS [27]

Ana (1). Aparece formando parte de la escena en el documento siguiente Catalina [(6), 1648-1684]

- quadro sin guamecer en bastidor de Ntr. Señor y Santana y Santa Catalina y el niño Jesüs y un Angel, 16 rs. 1648. Cepeda, dote de M." Fernández (Prot. 5982, f. 65) ${ }^{31}$

f. $216 v)$

- otro [quadrol de Santa Catalina. 1649. Cepeda. Inventario (Prot. 5982,

- quadro de Santa Catarina. 1658. Cepeda, inv. M. ${ }^{2}$ González, Vd. (Prot. 5984, f. 65)

- quadro de St. ${ }^{a}$ Catarina. 1662. Cepeda, inv. Antonio ahumado (Prot. 5985, f. 96v)

- quadro de Santa Catalina. 1675. Cepeda, inv. Domingo Rodríguez (Prot. 5989, f. 102)

- Una Santa Catalina en bastidor. 1684. Cepeda, inv. Francisca Sánchez (Prot. 5991, ff. 127 y ss.)

Clara [(2), 1675-1678]

- quadro de Santa Clara. 1675. Cepeda, inv. Domingo Rodriguez (Prot. 5989 , f. 102)

- quadros de Santa Clara l..J 1678. Cepeda, inv. M. Sánchez, Vd." (Prot. 5989 , f. 168)

Inés [(3), 1642-1684]

- Quadro de Santa Inés. 1642. Cepeda, inv. Juan Fernández, Maestro (Prot. 5981, f. 17v)

30 Cinta, generalmente de seda, con el nombre y la imagen de la devoción pintados o impresos. De dos dedos o terciada su anchura y de largo la medida exacta de la advocación, de donde deriva su nombre. Se adquiría en el propio santuario junto a estampas, láminas, medallas, relicarios y otras hechuras.

31 En estos desposorios místicos de Santa Catalina aparece dos veces -suponemos que por lapsus del escribano- la figura de Jesús. Donde dice "Ntr. ${ }^{\circ}$ Señor. deberá leerse

-Ntr. ${ }^{2}$ S.". , que compartiría el Niño con Santa Ana. Desconocemos si el ángel sólo contemplaba la escena en devoto segundo plano o viene a suplir a cualquiera de las santas testigas tradicionales (Lucía, Inés, Úrsula, Bárbara, Cecilia, etc.), y a veces, oficiantas. 
- quadro de Santa Inés de los corderos. 1649. Cepeda. Inventario (Prot. 5982, f. 216v) ${ }^{32}$

- Santa Inés en bastidor. 1684. Cepeda, inv. Francisca Sánchez (Prot. 5991, ff. 127 y ss. )

Juana [(1), 1673]

- otra lámina de Santa Juana, guarnecida de bilo de oro y plata y sedas de diferentes colores. 1673. San Martín, inv. Francisco López (Prot. 6190, ff. 12 y ss.) ${ }^{33}$

Lucia [(1), 1679]

- quadro de Santa Luzía. 1679. San Martín. Inventario (Prot. 6191, f. 25)

M." Egipciaca [(1), 1694]

- quadro con Santa M. Gicíaca y otro santo. 1694. Cepeda, inv. Domingo Calbo (Prot. 5994, f. 104)

M." Magdalena [(7), 1642-1675]

- Quadro de la bendita Madalena. 1642. Cepeda, inv. Juan Fernández, Maestro (Prot. 5981, f. 17v) ${ }^{34}$

- estampa de la adoración de la magdalena quando se le apareció el Señor. 1651. San Esteban, test. ${ }^{\circ}$ Beatriz de Linares (Prot. 6187, f. 78v)

- quadro de la Magdalena. 1651. Cepeda, inv. Antonio Corral (Prot. 5983, f. 250)

- estampa de la madalena en papel sin marco. 1668. San Martín. Inventario (Prot. 6189, ff. 195 y ss.)

- quadro pequeño con su marco todo de tabla en que está Pintada una imagen de Nt. ${ }^{\circ}$ Redentor Jxt..$^{\circ}$ crucificado y la Madalena y Santo Domingo. 1672. San Martín. Inventario (Prot. 6190, f. 44) ${ }^{35}$

32 No hay otra Inés que haga sombra a la ede los corderos", ni el Bautista se apellida "del cordero" para diferenciarse del Evangelista. En todo caso, debería ser "la del cordero" o "con el cordero", aunque no se habla de Catalina la de la rueda. Tampoco puede atribuírsele un supuesto patronazgo sobre los pastores que ya ostentaba Santa Marina. Estaba, sin darse cuenta, dejándose guiar el que hacía inventario por alguna cancioncilla, alboral u oración en que el atributo originario -un solo cordero- se convirtiera en rebaño y por ello en devota anécdota, ¿debilidad a la que quizá también cedió más de un pintor?

33 La guarnición que se describe en esta lámina es característica de la labor llamada ¿de monxas".

34 La Magdalena y San Antón comparten en los inventarios, podemos decir que en exclusiva, la invocación de abenditos. como intercesores socorridos a los que confiadamente recurren los fieles. Con este apelativo de "bendita" se reconoce también a Magdalena en el Cancionero y Refranero junto al de «apóstola de los apóstoles. De igual manera, los de egloriosos. van asociados a Santa Ana y San Roque por el poder que obtienen, cercanos a Dios.

35 Ver nota núm. 13. 
- Una lámina efigie de la Madalena con su marco guarnecido de cañamazo. 1673. San Martín, inv. Francisco López (Prot. 6190, ff. 12 y ss.)

- quadro de la Magdalena. 1675. Cepeda, inv. Domingo Rodríguez (Prot. 5989, f. 102)

Rosa [(1), 1694]

- quadro de Santa Rosa. 1694. San Martín, inv. Isabel Sanz (Prot. 6193, f. 39)

Teresa [(4), 1649-1698]

- quadro de Nuestra Madre Teresa de Jesús. 1649. Cepeda. Inventario (Prot. 5982, f. 216v)

- Laminita de Santa Teresa y San Josepe con vidriera. 1690. Cepeda, inv. Lcd. ${ }^{\circ}$ Manuel Pérez de Toribio, Pbr. $^{\circ}$ (Prot. 5993, f. 146)

- otro [quadro] de Santa Teresa. 1694. San Martín, inv. Isabel Sanz (Prot. 6193, f. 39)

- Lámina con la Santa Madre Teresa de Jesús. 1698. Sequeros, inv. Isavel Pérez (Prot. 6234, f. 259v) ${ }^{36}$

SANTOS [43]

Agustín [(2), 1642-1649]

- quadro de San Agustín. 1642. Cepeda, inv. Juan Fernández, Maestro (Prot. 5981, f. 17v)

f. 216v)

Andrés [(2), 1651-1690]

- quadro de San Felipe y San Andrés. 1651. Cepeda, test." Francisco Xil, zapatero (Prot. 5983, f. 4)

- Quadro de San Andrés. 1690. Cepeda, inv. Lcd." Manuel Pérez de Toribio, pbr. ${ }^{\circ}$ (Prot. 5993, f. 146)

\section{Ángel de la Guarda [(2), 1649-1690]}

- otro lquadrol del Angel de la Guarda. 1649. Cepeda. Inventario (Prot. 5982, f. 216v)

- Lámina del Angel de la Guarda. 1690. Cepeda, inv. Lcd. Manuel Pérez (Prot. 5993, f. 146)

Antonio [Abad] [(3), 1652-1690]

- una caxita con una imaxen de San Antonio. 1652. Sequeros. Inventario (Prot. 6224, f. 139v)

36 Este apelativo antonomásico de Madre se trasvasa y generaliza fuera de los propios términos del Carmelo, donde era lógico que se utilizara. Con el nombre de santa Madre. o -firma de la Santa Madre. lo encontramos también en documentación sobre relicarios. 
- quadro de San Antonio, 10 rs. 1675 (Prot. 6190, f. 97)

- Quadro del Bendito San Antonio. 1690. Cepeda, inv. Lcd. ${ }^{\circ}$ Manuel Pérez de Toribio, pbr. ${ }^{\circ}$ (Prot. 5993, f. 146) ${ }^{37}$

Antonio de Padua [(1), 1690]

- Lámina de San Antonio de Padua bordado de filigrana de plata. 1690. Cepeda, inv. Lcd. ${ }^{\circ}$ Manuel Pérez [...] (Prot. 5993, f. 146)

Blas [(1), 1686]

- echura de San Blas. 1686. Sequeros, inv. Francisco Rodríguez (Prot. 6230 , f. 80 )

Domingo [(3), 1671-1686]

- Retrato de Santo Domingo sin marco. 1671. San Martín, inv. Domingo Garzía Callejo, escribano del n. ${ }^{\circ}$ de esa villa (Prot. 6189, f. 33)

- quadro pequeño [..J y Santo Domingo (junto con el Crucifijo y la Magdalena. 1672. San Martín. Inventario (Prot. 6190, f. 44) ${ }^{38}$

- otro quadro de Santo Domingo. 1686. Sequeros, inv. Francisco Rodríguez (Prot. 6230, f. 80)

Felipe [(1), 1651]

- quadro de San Felipe y San Andrés. 1651. Cepeda, test. ${ }^{\circ}$ Francisco Xil, zapatero (Prot. 5983, f. 4) ${ }^{39}$

Francisco [(12), 1657-1699]

- id [quadrol de San Francisco, $500 \mathrm{mrs}$. 1657. Cepeda, inv. Francisco Garzía y su muxer M. ${ }^{2}$ Velasco (Prot. 5984, f. 95v)

- imagen de San Francisco en estampa de papel con marco por dorar. 1668. San Martín. Inventario (Prot. 6189, ff. 195 y ss.)

- lienzo en que está pintado San Francisco. 1671. San Martín, inv. Vd. ${ }^{a}$ de Francisco del Mercado (Prot. 6189, f. 10)

- quadro pintado de San Francisco. 1673. San Martín, inv. Francisco López (Prot. 6190, f. 12 y ss.)

- quadro de San Francisco. 1675. Cepeda, inv. Domingo Rodríguez (Prot. 5989, f. 102)

- quadros de Santa Clara, San Pedro y San Francisco. 1678. Cepeda, inv. M. ${ }^{2}$ Sánchez, vd." (Prot. 5989, f. 168)

37 El San Antonio por antonomasia que no necesitaba en estos siglos de apellido era el Abad o San Antón, sí el de Padua que, hasta el siglo xrx, no parece alcanzar la popularidad devocional de que goza hoy.

38 Ver nota núm. 13.

39 Es uno de los escasos ejemplos de santos geminados. Quizá iban formando un Apostolado con otros cinco perdidos, aunque San Felipe suele ir en pareja con Santiago el Menor, también llamado el Verde. 
- otro lquadrol de San Francisco. 1679. San Martín. Inventario (Prot. 6191, f. 25)

- dos quadros de San Francisco. 1686. Sequeros, inv. Francisco Rodríguez (Prot. 6230, f. 80)

- Lámina de Nuestro Padre San Francisco. 1690. Cepeda, inv. Lcd Manuel Pérez [...] (Prot. 5993, f. 146)

- una imaxen de San Francisco con dos florones a los lados. 1694. Sequeros, inv. Inés Díez Cordera (Prot. 6233, f. 222)

- quadro pintado con Nuestro Señor Santo Xt. $y$ Nuestro Padre San Francisco. 1699. Sequeros, inv. Catalina Garzía (Prot. 6235, ff. 19 y ss.) to

Jerónimo [(1), 1694]

- quadro de San Jerónimo. 1694. San Martín, inv. Lcd Francisco Ximénez, párroco (Prot. 6193, f. 16 y ss.)

José [(2), 1673-1682]

- Lámina de San Joseph con sus vidrieras. 1673. San Martín, inv. Francisco López (Prot. 6190, ff. 12 y ss.)

- Lámina con San Joseph. 1682. Cepeda, inv, Ana Domínguez (Prot. 5991, ff. 139 y ss.) ${ }^{41}$

Juan Bautista [cuando va a secas es el Bautista] [(5), 1642-1697]

- un San Juan de cera la echura. 1642. Cepeda, inv. Juan Fernández, Maestro (Prot. 5981, f. 17v) ${ }^{42}$

- Echura del Señor San Juan con un arcaz, 8 rs. 1648. Cepeda, dote de M. ${ }^{2}$ Fernández (Prot. 5982, f. 65) ${ }^{43}$

40 Entre los once ejemplos de San Francisco documentados en esta centuria -el de mayor acogida doméstica-, únicamente el inventario de Catalina García (1699) aclara su iconografía, el abrazo místico con el Crucificado. Sólo el del inventario de Inés Díez Cordera (también en Sequeros y año 1694) era de bulto; seguramente llevaba en la mano derecha el Cristo y la otra sobre el pecho, en actitud de vehemencia contemplativa. ¿Mantendría alguno de los nueve restantes la vieja fórmula de los estigmas?

${ }^{4}$ En ninguno de estos ejemplos sobre San José - fueran de media figura o de cuerpo entero- se describe compañía alguna, pero este santo no puede aparecer solo y es seguro que no iba geminado con María, pues se hubiera dicho. Sí, en cambio, llevaría necesariamente Niño en el brazo o de la mano (innovación salmantina de Juan Rodríguez), que había ya pasado a ser atributo identificatorio, igual que la azucena.

42 Único caso serrano en este siglo con hechura de cera. Lo habitual eran las figuras de media hechura para cuadros-escaparate. Tanto estas como las de bulto eran vestideras.

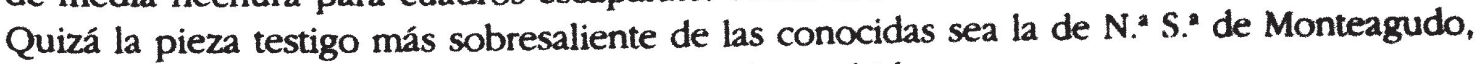
en el claustro alto de las Descalzas Reales de Madrid.

43 Desconocemos el sentido de este arcaz, incorporado según parece a la figura del santo. Si este enser se presentara como atributo habría de ser arcacita y no arcaz, al menos que pensáramos en la tinaja del martirio del, en ese caso, Juan Evangelista ante portam latinam. 
- quadro de un San Juan. 1660. Cepeda, inv. Francisco Felipe (Prot. 5985 , f. 60 )

- Estampa de San Juan en papel. 1668. San Martín. Inventario (Prot. 6189, ff. 195 y ss.)

- quadro de San Juan, 6 rs. 1697. Sotoserrano. Inventario (Prot. 6305, f. 56)

Juan Evangelista [(1), 1649] [ver en apartado II, lo relativo a la voz Calvario, nota 9, p. 227]

Juan de los Santos [(1), 1648]

- Imagen de San Juan de los Santos, frayre descalzo de la trinidad. 1648. Cepeda, dote de María Fernández (Prot. 5982, f. 65)

Marcos [(1), 1682]

- dos láminas con San marcos y San Joseph. 1682. Cepeda, inv. Ana Domínguez (Prot. 5991, ff. 139 y ss.) ${ }^{44}$

Onofre [(1), 1657]

- quadro de San Onofre, 500 mrs. 1657. Cepeda, inv. Francisco García y su muxer M. ${ }^{a}$ Velasco (Prot. 5984, f. 95v)

Pedro [(2), 1678-1686]

f. 168)

- quadro de San Pedro. 1678. Cepeda, inv. María Sánchez (Prot. 5989,

- otro quadro de San Pedro. 1686. Sequeros, inv. Francisco Rodríguez (Prot. 6230, f. 80)

Tomás de Aquino [(1), 1673]

- quadro de tres quartas de largo con su marco, imagen de Santo Tomás de aquino. 1673. San Martín, inv. Francisco López (Prot. 6190, ff. 12 y ss.)

Santo trinitario [(1), 1659]

- quadro de un religioso de la orden de los Trinitarios descalços. 1659. Cepeda, inv. D. ${ }^{a}$ M. ${ }^{a}$ Gutiérrez, muxer de Jerónimo de la Alverca (Prot. 5985, f. 9) ${ }^{45}$

4 No parece casual que el único ejemplo advocacional de San Marcos lo registre Cepeda, villa donde se veneraba en ermita propia por lugareños y comarcanos, contando con feria muy afamada y cofradía con bula del papa Alejandro VII, de 29 de mayo del año 1656 (Arch. Parroq. Cepeda. Becerro de 1766, f. 279).

45 Se identifica con precisión esta Orden de Cautivos por la cruz encarnada y azul del hábito, pero el atributo común de las cadenas no ayudó en este caso a descifrar el santo, que no llevaría leyenda al pie. 
Otros santos sin especificar [(11), 1690]

- más otros once quadros pequeños [..] de diferentes santos y santas. 1690. San Martín. Inventario (Prot. 6192, f. 119) ${ }^{46}$

\section{TEMAS DEL ALMA O POSTRIMERÍAS [10]}

Las cuatro (o tres) ánimas [(8), 1649-1684]

- un quadro de las quatro ánimas que llaman, del cielo, purgatorio, infierno y limbo. 1649. Cepeda. Inventario (prot. 5982, f. 167)

- tres quadros de las tres ánimas: cielo, purgatorio e infierno. 1651. Cepeda, inv. Antonio Corral (Prot. 5983, f. 290)

- Cuatro láminas del Purgatorio, Gloria, Limbo, ynfierno. 1684. Cepeda, inv. Francisca Sánchez (Prot. 5991, ff. 127 y ss.)

La escala del cielo [(1), 1690]

- Otro [quadro] del Camino del cielo con una cruz y unas escalas. 1690. San Martín. Inventario Prot. 6192, f. 119)

El Justo Juez y Redentor [(1), 1659]

- una imagen de Nuestro Señor del Juicio. 1659. Cepeda, inv. D. ${ }^{a}$ M. Gutiérrez (Prot. 5985. f. 9) ${ }^{47}$

* De las 293 entradas registradas en el siglo XVII, tan solo 11 escapan, por razones que desconocemos, a la identificación de peritos y escribanos.

F El tema conocido en estos años como de "las tres" o las "cuatro* ánimas cuyos ejemplos son exclusivos de la villa de Cepeda, se presentan, según vemos, en dos variantes: agrupados en sola composición o desglosados formando serie. La del limbo falta en el inventario de Antonio Corral (año 1611). En los ejemplos que sobre estas series conocemos en colecciones de joyas-relicario, casi siempre en cera, suele prescindirse también de esa postrimería cuyo lugar ocupa la muerte. A partir de la segunda mitad del siglo XVIII prevalece como devoción popular solo la del purgatorio (en iglesias, ermitas y humilladeros) asociada a la iconografía carmelitana. Si bien en el área Norte peninsular, especialmente Galicia, la figura de la Virgen sacando las ánimas del fuego con el escapulario, cede a veces a la de San Francisco, a cuyo cordón se aferran aquellas, también a la figura del Espíritu Santo y a la del Sacramento, o se presentan todas formando grupo. Es el caso del lienzo albercano que cuelga en el presbiterio de la parroquial del lado del Evangelio. El tema de la "escala del cielo" contaba en su composición según el inventario de San Martín de Castañar, con cruz y escalas por donde subirían las almas, de acuerdo con el adagio: ad lucem per crucem. El tercero y último es el del "Justo Juez", también en inventario de Cepeda (1659) que no proporciona un solo detalle, ni siquiera de calidad, aunque parece lógico que fuera obra devota, no de la Deesis, sino del Juicio Universal con sus condenados y bienaventurados. Sobre las postrimerías solo volveremos a contar con un ejemplo en inventario de Sequeros y año 1706, pero sí media docena de títulos equivalentes en bibliotecas serranas del siglo XViI y en una candelaria, ya en 1830, algunos de cuyos libros que inventariamos a continuación se describen como muy viejos: "Unas llaves del paraíso. (Sequeros, inv. 
V. EL PAís [(1), 1675]

- quadro con país, 10 rs. 1675. San Martín. Inventario (Prot. 6190, f. 97)

Pais de Caza [(1), 1671]

- otro país pequeño en que está pintada una montería. 1671. San Martín. Inventario (Prot. 6189, sf.) ${ }^{48}$

VII. EL BODEGÓN [no hay ejemplos en este siglo]

VIII. TEMAS mitológicos, alegorías y Emblemas [no hay ejemplos en este siglo]

DX. EL RETRATO $[(2,1671]$

- otro quadrito pequeño, retrato de Juan del Mercado. 1671. San Martín, inv. Vd. ${ }^{a}$ de Francisco del Mercado y mujer de Domingo Hidalgo (Prot. 6189, f. 10$)^{49}$

- Retrato de Santo Domingo sin marco. 1671. San Martín, inv. de Domingo García Callejo (Prot. 6189, sf.) ${ }^{50}$

X. PERSONAJĒS hISTÓRICOS [no hay ejemplos en este siglo]

XI. OTROS PERSONAJES Y TEMAS [no hay ejemplos en este siglo]

de 1749, Prot. 6244, f. 197). Jornada para el cielo y jardín florido del alma. (Sequeros, 1707, inv. de Pedro Anaya Zebrián. Prot. 6237, ff. 4v y ss.). .Itinerario del Cristiano para caminar al cielo. (San Martín, 1789. Inventario. Prot. 6207, ff. 19-19v). "Uno muy viejito de Grittos de las Animas, un realn (Candelario, 1779, inv. de Pedro Rico, Prot. 1140, f. 21). "Gritos del Ynfierno" (San Martín, inv. de 1742. Prot. 6203, f. 61). "Gritos del Pungatorio, cuatro rs; Práctica de vien morir, un tomo, $4 \mathrm{rs}$; los ochos tomos de Mística ciudad de Dios, 30 rs" (Candelario, 1830. Bienes de M. ${ }^{2}$ López Rico. Prot. 1152, sf.).

48 De estos dos sujetos que nos proporcionan los inventarios en los años setenta del siglo xvil, ambos en San Martín del Castañar, el segundo país no solo presentaba animales como era lo más habitual, sino animales siendo cazados.

49 Seguramente este Juan del Mercado era padre de Francisco del Mercado cuya casa habitaba su viuda y actual mujer de Domingo Hidalgo. Ella debió dejar transcurrir el tiempo legalmente establecido, por lo regular dos años, antes de desposarse de nuevo, sin que algún cuñado reclamase para sí la parte del difunto. El retrato pudo muy bien ser obra de su nieto Francisco, pintor, de quien sabemos que realizó unas pinturas en el año 1697 para el humilladero de San Martín: “...que pagó a fio del Mercado por las pinturas que hiço en la ermita, en que fue concertado, que hacen mrs. 11.900. (A.P.S. Martín, Cuentas del Humilladero de 1693 a 1797, año 1697, f. 11).

50 Domingo García, escribano de número de la villa de San Martín, no figura así en el Archivo de Protocolos, constando como tal Don José García del Castillo desde 1668 a 1679 (Protocolos 6189 a 6191). 
XII. LA DENOMINACIÓN DE PROCEDENCIA DESPLAZA EL. TEMA DE LA OBRA [16]

Obra de Francia [(2), 1671]

- dos papeles de pinturas francesas largos. 1671. San Martín, inv. vd. a de Francisco del Mercado (Prot. 6189, f. 10)

Obra de Sevilla [no hay ejemplos]

Obra de Valencia [no hay ejemplos]

Obra de Valladolid [(13), 1696-1697]

- once quadros, de los de Valladolid los nueve y dos de los que quedaron del retablo. 1696. Cepeda, inv. de Francisco Martín (Prot. 5995, ff. 12-15) ${ }^{51}$

- dos quadros de diferentes pinturas nuevas de Valladolid. 1697. San Martín, inv. de Antonia Rodríguez (Prot. 6193, f. 113) ${ }^{52}$

Escaparates y obra de monjas [(1), 1690]

- Relicario en quadro con su vidriera y dorado. 1690. Cepeda, inv. Icd. ${ }^{\circ}$ Manuel Pérez de Toribio, pbr. ${ }^{\circ}$ (Prot. 5993, f. 146).

XIII. TEMAS SIN IDENTIFICAR [45]

- más otros once quadros ya algo antiguos de diferentes santos y santas. 1690. San Martín. Inventario (Prot. 6192, f. 119)

- cinco estampas de papel. 1691. Cepeda. Inventario. (Prot. 5993, ff. $17-17 \mathrm{v}$ )

- quinze quadros viexos de diferentes santos mediados, más tres quadros más pequeños, quatro estampas pequeñas y siete láminas. 1695 (Prot. 6194, f. 211v)

51 Dicho Francisco Martín debía ser hijo de Antonio Martín, quien ejerció en esa villa como escribano desde el año 1648 hasta el del 1681 en que fallecería (Protocolos 5982-5900), pues a partir del año 82 figura ya Martín Panchuelo. Este Francisco Martín supo valorar como coleccionista las tablas - para los demás inservibles- que quedaban del antiguo retablo de epincel. y que vemos mencionadas en la sacristía según libro de fábrica, dos de las cuales pasaron a su casa. La obra del nuevo retablo se había rematado en 2.403 reales, trece años antes, el 28 de diciembre de 1683, en la persona de Ambrosio de Villalobos, "maestro ensamblador y tallador", vecino de Alba de Tormes. En las condiciones se dice de esa nueva máquina, que era de toda talla. según rezaba la traza que paraba en poder del presbítero Manuel Pérez, más las condiciones que Juan Hernández, emaestro de dicho arte, puso en dicho papel. (AHPS. Prot. 5991, ff. 217-218v)

52 De los trece cuadros de Valladolid de los que no se citan títulos, solo dos se califican de nuevos", por lo que no parece temeridad suponer esta procedencia como arraigada en la serranía salmantina tiempo atrás. 


\section{SIGLO XVIII}

I. Escenas del Antiguo Testamento [1]

David, el rey pastor [(1), 1742]

- pintura de David apazentando el ganado. 1742. Sequeros, inv. Díez Zúñiga Palomeque (Prot. 6243, f. 205) ${ }^{53}$

II. Temas del Nuevo Testamento [107]

VIDA DE CRISTo [14]

Nacimiento [(2), 1742-1761]

- pintura del Nazimiento con marco nuevo y tarjetas doradas de media vara, 30 rs. 1742. Sequeros, partija de los hijos de Don Francisco Díez (Prot. 6243, ff. 196 y ss.)

- Quadro del Nazimiento, 10 r. 1761. Miranda. Inventario (Prot. 6165, f. 16v)

Nombre de Jesús [(1), 1712]

- Quadro del Nombre de Jesús, fábrica de Balladolid, 3. 1712. Candelario. Inventario (Prot 1133, f. 54) ${ }^{54}$

Circuncisión [(1), 1742]

- Dos pinturas, la una de la Zircunzisión. 1742. Sequeros, partija de los hijos de Don Francisco Díez (Prot. 6243, ff. 196 y ss.)

Epifanía [(1), 1754]

- quadro de la adorazión de los Reyes. 1754. Miranda, inv. Joseph Martín de Tapia (Prot. 6176, f. 209)

Transfiguración [(1), 1742]

- Dos pinturas (...), la otra del Monte Thavor. 1742. Sequeros, partija de los hijos de Francisco Díez (Prot. 6243, ff. 196 y ss.)

53. Si no suponemos en esta obra al rey-pastor con corona y arpa o su leyenda al pie, no parece tema demasiado fácil de identificar y podría muy bien pasar por lo que se documenta en esta época como "país de caza".

5. Si era esta obra de las desarrolladas en anagrama con el JHS y tondo alrededor, ángeles portadores o en gloria rompiente, debe considerarse rara, como lo fueron los corazones sagrados de Jesús y María, aislados de los cuerpos, tendencias que desaprobó en su momento la Iglesia como idolátricas. Sí abundan, en cambio, los JHS y la M.a en la joyería popular, sacralizando en el siglo XVIII piezas tan comprometidas como las mediaslunas y otros amuletos. 
última cena [(1), 1737]

- paño de pintura [con] la zena del Señor y su Instituzión, en dos ducados. 1737. Sequeros, inv. Dorotea Rodríguez (Prot. 6241, f. 79) 55

Coronación de espinas [(1), 1721]

- Cristo comonado de espinas. 1721. San Martín. Inventario (Prot. 6199, f. 124v)

Cruz a cuestas [(1), 1705]

- quadro de Cristo con la cruz a cuestas, 3 r. 1705. Candelario. Inventario (Prot. 1132, f. 23)

\section{Descendimiento [(1) 1765]}

- un quadro del descendimiento del Rendentor con su marco, 15 rs. 1765. Miranda, inv. Antonio Rodríguez de Ledesma, pbr. ${ }^{\circ}$ (Prot. 6148, ff. 3 y ss.)

Santo Sepulcro [(2), 1701-1736]

- quadro grande del Santo Sepulcro. 1701. San Martín, inv. Boticario (Prot. 6194, f. 104)

- un quadro del Santo Sepulcro. 1736. Sequeros, inv. de Santos de Frías en dote con Josepha de Borxa (Prot. 6240, f. 75) ${ }^{56}$

Trinidad [(2), 1712-1743]

- Quadro de la Trinidad. 1712. Candelario. Inventario (Prot. 1133, f. 54)

- quadrito de marco tallado de la Trinidad, 6 r. 1743. Candelario, inv. Pedro Batanero (Prot. 1137, f. 29v)

Vida de María [4]

Arbol de Jesé [(1), 1737]

- Dos paños de pintura sin marco, en uno los profetas y Descendenzia de Maria Santísima len el otro la Cenal en cuatro ducados lentre los dosl. 1737. Sequeros, inv. Dorotea Rodríguez (Prot. 6241, f. 79) ${ }^{5}$

Anunciación [(1), 1742]

- Dos pinturas de una Salutación y María l... J con sus marcos negros y tarjetas doradas de vara y quarta de larga, a $50 \mathrm{rs}$. cada uno. 1742. Sequeros, partijas de hijos de Francisco Díez (Prot. 6243, ff. 196 y ss.)

55 Ignoramos la razón por la que esta obra se tasa con precio tan subido, siendo además "paño de pintura", en cuya composición no se expresa riqueza alguna. No alcanzan este valor obras consideradas "de pintura fina", ni aún las de guamición con tarjetas de oro.

i6 No debió prodigarse esta escena de la Pasión, ensombrecida entre las tan patéticas del Descendimiento y Llanto sobre Cristo muerto por una lado, y las triunfales de la Resurrección y Apariciones del "Aleluya" del otro, por lo que son más de agradecer estos testimonios de San Martín y Sequeros.

57 Ejemplo de iconografía residual, en boga durante los siglos xv y xv, aunque no va descrita la pieza como antigua o vieja. 
Presentación [(1), 1736]

- quadro pequeño de la Presentazión de Nuestra Señora. 1736. San Martín. Inventario (Prot. 6202, f. 130v)

Asunción [(1), 1742]

- pintura de $N^{a} S^{a}$ de la Asumpción, con su marco negro y tarjetas doradas, de tres quartas de alto, en 40 rs. 1742. Sequeros, partija hijos de Don Francisco Díez (Prot. 6243, ff. 196 y ss.)

Personaves aislados (16)

Ecce Homo [(9), 1705-1782]

f. 23)

- quadro de un eccebomo, 3 rs. 1705. Candelario. Inventario (Prot. 1132,

- quadro de un ezeomo, 5 rs. 1726. Sequeros. Inventario (Prot. 6239, f. 97v)

- quadro viejo de un EcceHomo, 1 rl. 1738. Sequeros, inv. María Anaya (Prot. 6241, f. 89v)

- otro [quadrol del ezeomo. 1742. San Martín. Inventario (Prot. 6199, f. $124 v)$

- un eccebomo en una cajita, de escultura. 1749. Sequeros, inv. Antonio Hernández (Prot. 6244, ff. 179-185)

- Un ecce-bomo con marco blanco, 30 rs. 1758. Sequeros, inv. Mariana Garzía Rubio (Prot. 6247, ff. 45v y ss.)

- un zeomo con su quadro. 1764. Sequeros, inv. Agustina González, vd. ${ }^{a}$ de Francisco Berrocal (Prot. 6248, f. 6)

- Eccebomo de yeso, 4 rs. 1772. Villanueva, dote de Isabel Sanz (Prot. 6322, sf.)

- quadro del ecceomo. 1782. San Martín. Inventario (Prot. 6207, fs.)

Nazareno [(4), 1742-1783]

- quadrito de Jesús Nazareno. 1742. San Martín. Inventario (Prot. 6199, f. $124 v)$

- dos quadros viejos de Jesús Nazareno, pintado en estopa grande. 1776. Sequeros, inv. Úrsula Muñoz (Prot. 6251, ff. 115 y ss.)

- quadro grande de Jesús Nazareno, 30 rs. 1783. Miranda, inv. Juan Hernández Tapia (Prot. 6152, f. 24v) ${ }^{58}$

\footnotetext{
so Debemos entender por Ecce Homo la tipología - popular o no- tan atribuida a Morales el divino y que presenta, de hecho, a Cristo en su Flagelación. Por Nazareno, la de Jesús con túnica, generalmente morada, y las manos atadas, lo que correspondería en realidad a la secuencia del Ecce Homo y Pilatos o, si carga con la cruz, el Camino del Calvario. Ambos (Ecce Homo y Nazareno) como se ve a menudo, fundidos o confundidos, se adscriben al tema del vir dolorum.
} 


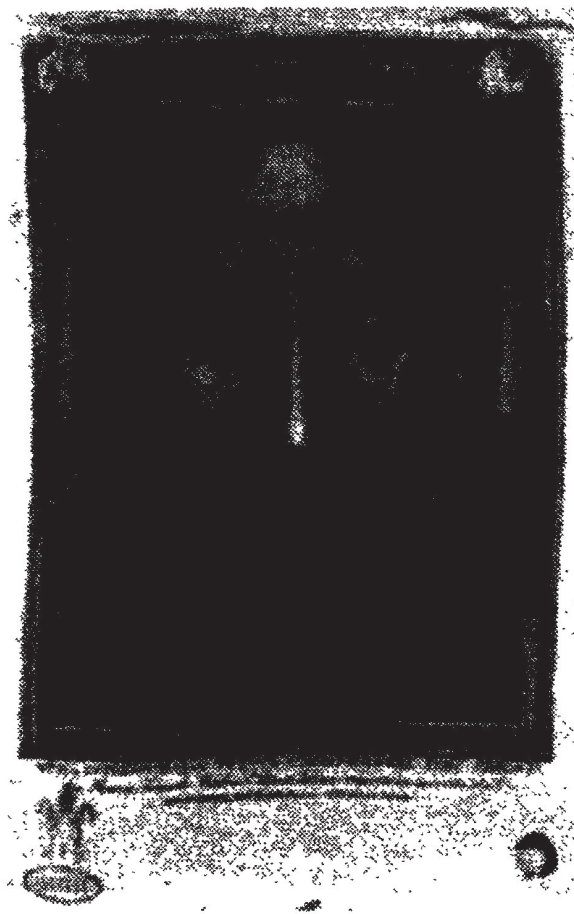

LÁM. VII.-Grabado sobre seda de la Verónica de Cristo, que se venera en San P..$^{\circ}$ de Roma. Por la espalda mantiene la auténtica, fechada en el año 1885 bajo el pontificado de León XIII (Roma, Ant. ${ }^{\circ}$ Schiavoni, Via Minerva 82. Col. part. Madrid).
Salvador [(3), 1712-1742]

- Quadro del Salvador, fábrica de Balladolid, 3 rs. 1712. Candelario. Inventario (Prot. 1133, f. 54)

- Lámina del Salvador con marco dorado de cobre. 1715. Miranda, inv. Don Jerónimo Rodríguez de Ledesma, pbr.' (Prot. 6144, ff. 51 y ss.)

- Salvador con su marco. 1742. Sequeros, partijas hijos de Don Francisco Diez (Prot. 6243, ff. 196 y ss.)

\section{Detalles sobre una persona [6]}

Verónica [(5), 1704-1764]

- echura de berónica. 1704. Cepeda, inv. Juan González, Herrador (Prot. 5997, f. $99 \mathrm{v}$ )

- una quadro con una berónica. 1729. Cepeda. Inventario (Prot. 6000, f. 62)

- tres Berónicas, dos de yeso y una de madera. 1764. Sequeros, inv. Agustina González, vd.a de Francisco Berrocal (Prot. 6248, f. 6)

Santo Rostro [(1), 1785]

- Imagen estampa del Santísimo Rostro. 1785. Cepeda, inv. Sebastián Blanco (Prot. 6014, ff. 148 y ss.)

\section{La SAgrada Fammia (4)}

\section{Nuestra Señora, San José y el Niño} [(2), 1715-1754]

- Lámina de $N^{a}{ }^{\text {S }}$., San Joseph y el Niño de cobre. 1715. Miranda, inv. Don Jerónimo Rodríguez de Ledesma y San Miguel (Prot. 6144, ff. 51 y ss.)

- otro quadro de papel de la Sacra familia. 1754. Sequeros, inv. Juan Antonio Anaya (Prot. 6246, f. 164)

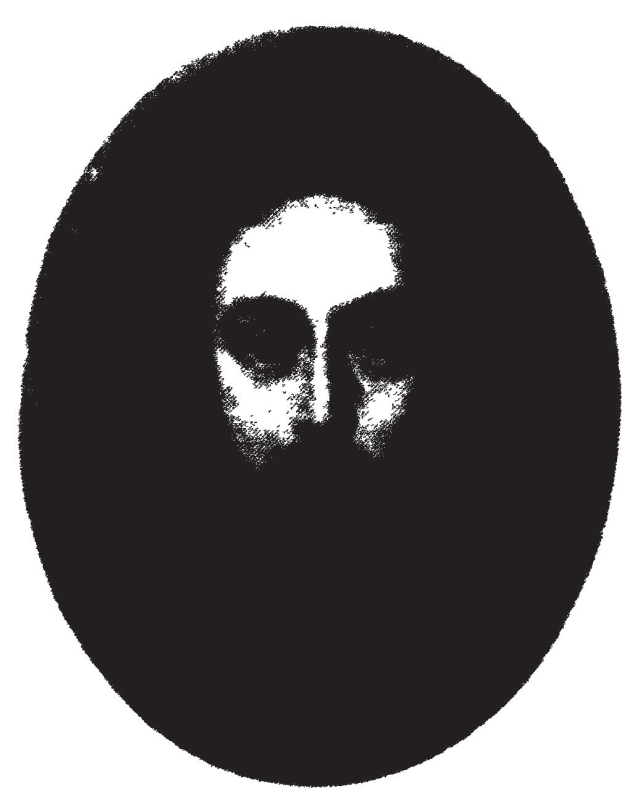

LÁM. VIII. - Lámina sobre cobre del Rostro de Dios con la conocida leyenda al pie: ‘V. Imago Salvatoris/ ab ipso Dno expressal et ad R. Abagarum missar. (S. XVII, col. part. Madrid). 
Nuestra Señora y San José [(1), 1704]

- Nuestra Señora y San Joseph. 1704. Sequeros, inv. Juana de Guerta (Prot. 6237, ff. 39 y ss.)

San José, el Niño y San Juan [(1), 1742]

- Pintura de San Joseph, el Niño y San Juan con marco antiguo, 30 rs. 1742. Sequeros, partijas hijos de Francisco Díez (Prot. 6243, ff. 196 y ss.) 59

Niño Jesús [(12), 1704-1782]

- quadro del Niño Jesús. 1704. Sequeros, inv. Juana de Guerta (Prot. 6237, ff. 39 y ss.)

- una cara [sic por caxa] y en ella un Crucifixo y un Niño Jesús. 1704. Sequeros, inv. Fc. ${ }^{\circ}$ Hernández Montero, escribano (Prot. 6237, f. 23) ${ }^{60}$

- echura e un Niño Jesús. 1705. Candelario. Inventario (Prot. 1132, f. 101)

- bechura de un niño jesús con su peana. 1711. Cepeda, inv. lcd." Francisco Blanco

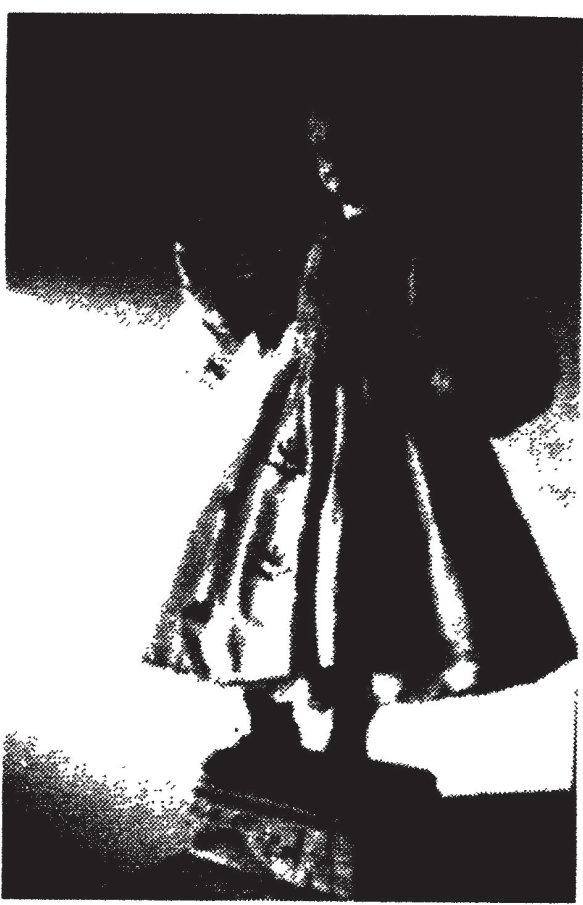

LÁM. IX. - Niño batuecom en figura de pequeño Salvador, bendiciendo y con orbe. Lleva ropas: camisón serrano, enaguas, polainas y sayo. (Talla en madera del s. XviI, Mogarraz, col. part. Foto A. Cea, 1978). (Prot. 5999, ff. 30-30v)

- cajita de pino guamecida de paja por dentro con un niño Jesús. 1712. San Martín. Inventario (Prot. 6196, f. 74v)

- Niño Jesís pintado en tabla, un rl. 1735. San Martín. Inventario (Prot. 6201, sf)

- una echura del un niño Jesús con su caja. 1736. Alberca, inv. Lorenzo Pérez Calama (Prot. 6104) ${ }^{61}$

- talla del Niño Jesús en 12 rs. 1737. Sequeros, inv. Ana Asenxio (Prot. 6240, f. 9v)

- una echura de un Niño Jesús, 50 rs. vellón. 1743. Alberca, matrimonio de Antonio Pies de la Guebra (Prot. 6106, f. 184)

- Un Niño Jesús de yeso en 2 rs. vellón. 1763. Sequeros, inv. Pedro Anaya (Prot. 6248, f. 173)

59 Las tres modalidades, salvo quizá la de Nuestra Señora y San José, no dejan de ser derivaciones sintetizadas de la Parentela de María.

(n) Este escribano cubre en su oficio los años 1690 a 1704 inclusive, en que debió fallecer (Protocolos 6231, 6236)

61 Lorenzo Pérez Calama debía ser pariente muy próximo de Manuel Pérez Calama, escribano de la Alberca desde 1727 a 1753 (Prot. 6102-6110). Le siguió Manuel de la Güebra de 1753 a 1764 (Prot. 6111-6115). 
- Un Niño Jesús con su bestido. 1764. Sequeros inv. Agustina vd." de Francisco Berrocal (Prot. 6248, f. 6)

- El Niño llevando los atributos de la Pasión. 1782. San Martín. Inventario (Prot. 6027, sf.) ${ }^{62}$

\section{Crucifijos y Cruces [(46), 1700-1786]}

- echura de un Cristo de plata abumado, 23 rs. 1700. Candelario. Inventario (Prot. 1132, f. 40v)

- echura de Cristo de bulto mediano. 1703. Cepeda. Inventario (Prot. 5996, f. 120)

- echura de Santo Cristo de barro, mas un quadro de Santo Cristo. 1704. Cepeda. Inventario (Prot. 5997, f. 302)

- Santo Cristo de bronce, it. cruz de madera y en ella embutido una echura de Cristo. 1704. Cepeda. Inventario (Prot. 5997, f. 329v)

- ecbura de un Santo Cristo en su Cruz, dorados los cavos y es de barro. Mas echura de un Cristo pequeño en su cruz de Bronce y extremos de bronce en la cruz. 1704. Cepeda, inv. Juan González, Herrador (Prot. 5997, f. 99v)

- un crucifixo con su caxa y cortina. 1704. Sequeros. Inventario (Prot. 6236, f. 12)

- echura de un crucifixo. 1704. Sequeros, inv. Juana de Guerta (Prot. 6237, ff. 39 y ss.)

- una caxa y en ella una echura de un crucifixo y un Niño Jesús, mas tres cruzes pequeñas. 1704. Sequeros, inv. Francisco Hernández Montero, escribano (Prot. 6237, f. 23)

- echura de un Crucificado de plomo. 1705. Sequeros, inv. Lcd." Francisco Hernández de Mateo (Prot. 6237, f. 16)

- una caja pequeña y en ella un Santo Xt." y a los lados San Francisco y Santa Ana, y una cruz sobre dicha caja. 1710. Miranda, inv. Isavel Cascón (Prot. 6144, f. 17v)

- un cruzifijo de plomo, $4 \mathrm{rs}$. (en que entra también un cuadro de Valladolid) 1711. Candelario. Inventario (Prot. 1133, f. 59)

- pintura de cruzifixo en una cruz. 1715. Sequeros. Inventario (Prot. 6238$, f. 35$)^{63}$

62 Aunque solo se especifican en este último documento de 1782 los atributos de la Pasión, conocidos también como improperios, estigmas, o vexilla regis, la mayoría de los Niños que no iban presentados como Salvadores en miniatura, llevaban de Nazarenos la cruz al hombro y, en una cestilla, la corona de espinas (compartida a veces con otra de flores a la cabeza), los tres clavos, la lanza, la escalera, la columna, los flagelos, etc.

63 Pinturas del Crucificado sobre cruces se conservan en esta región, sobre todo en ámbitos conventuales, algunas de gran calidad. Es el caso de la del coro bajo en el monasterio de las Úrsulas en la propia ciudad de Salamanca y legendariamente atribuida a la mano de Miguel Angel. 


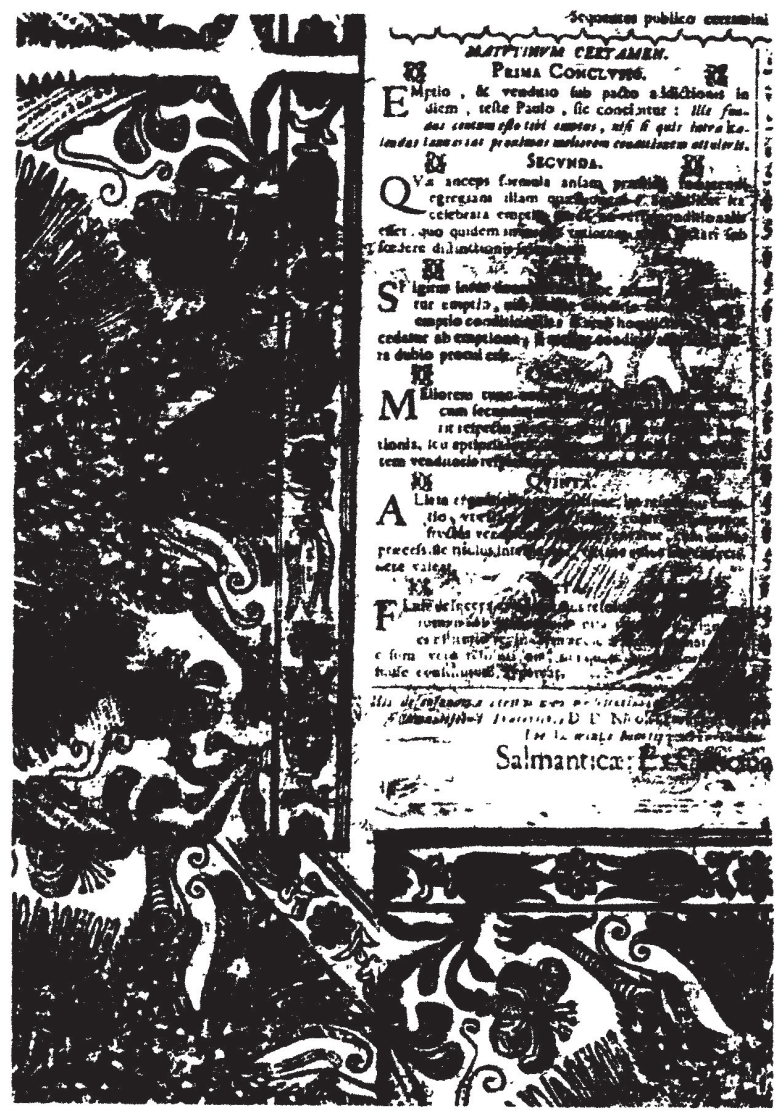

LÁM. X.-Las conclusiones, de seda o papel, se reutilizaban, a veces, como campo de cuadros o hechuras. Conclusiones defendidas el 12 de marzo de 1699 en el salmantino Colegio de San Pelayo. Impresas en Salamanca por Eugenio Antonio García (Madrid, col. part.).
- quadro de un cruzifixo. 1717. Sequeros, inv. María Garzía (Prot. 6239, f. 16)

- dos cruces de madera negra $y$ en ella unos Santos Cristos. 1718, Miranda, inv. Jerónimo Gutiérrez (Prot. 6144, f. 37v) ${ }^{64}$

- echura de un Santo Cristo con su cruz y cortinas de tafetán $y$ detrás una conclusión en su marco con cinco listones $y$ dos piezitas de alquimia, $60 \mathrm{rs}$. Un quadro cruzifixo con su marco dorado, $12 \mathrm{rs}$. 1726. Sequeros, test. ${ }^{\circ}$ Angela Rodríguez (Prot. 6239, f. 97v) 65

- cruz con vedriera y cortina y dosel. 1729. Cepeda. Inventario (Prot. 6000, f. 77v)

- efigie de un Santo Cristo mediano. 1741. Sequeros, inv. María Rodríguez Maldonado (Prot. 6242 , f. $269 \mathrm{v}$ )

\section{- pintura de un Cruzifixo con} sus marcos negros $y$ tarjetas doradas de vara y media de alto, $60 \mathrm{rs}$. Un Cruzifixo con su talla dorada en 50 rs. Una estampa de papel y en ella un Cruzifxo con dos tarjetas doradas. 1742. Sequeros, partijas hijos Francisco Díez (Prot. 6243, ff. 196 y ss.)

- un quadro con un crucifijo. 1744. Cepeda, inv. Catalina Sánchez (Prot. 6003 , f. $102 \mathrm{v}$ )

th Habría santos ocupando los extremos del palo y los brazos o embutideras con reliquias y sus nombres en ellas.

"s Se entiende por conclusiones las convocatorias o programas impresos en papel o tafetán de seda, con que la Universidad hacía públicas distintas teorías defendidas como tesis en concertaciones solemnes, y cuyas conclusiones iban todas especificadas, de donde derivó su nombre. No faltaba el lugar, hora y fiesta para la celebración, nombre del defensor, el del padrino y hasta los datos del impresor. Dichos anuncios eran con frecuencia reutilizados como en este documento de Sequeros, donde con su marco servía de fondo al Crucifijo. Uno de esta época en tafetán pajizo sirve hoy de almohadilla a la caja que guarda el rostrillo de la Virgen vestidera albercana. En el mismo siglo XVIII aparecen también documentadas en indumentaria unas llamadas "conclusiones de Santa Isabel. con las que no debe confundirse, refiriéndose ahora a colonias de seda o cintas para el pelo. 
- echura de un cruzifijo con cruz verde. 1745. Sequeros, inv. Antonio Martín Fraile (Prot. 6243, f. 137v)

- Un Cristo de bronce en una Cruz de madera teñida de negro. 1748. Sequeros. Inventario (Prot. 6244, f. 21v)

- la echura de un Crucifixo pequeño. 1749. Sequeros. Inventario (Prot. 6244, f. 196)

- quadro grande con marco, de hechura de un cruzifijo. 1754. Cepeda, inv. José Martín de Tapia (Prot. 6176, f. 209)

- crucifijo pequeño de yeso. 1758. Cepeda, inv. Catalina Sánchez (Prot. 6006 , sf.)

- Cruzifijo de bronze, 8 rs. 1758. Sequeros, inv. Mariana Garzía Rubio (Prot. 6247, ff. 45v y ss.)

- dos cruzes de madera con sus cruzifijos pequeños. 1765. Miranda, inv. Antonio Rodríguez de Ledesma, presvítero (Prot. 6148, ff. 3 y ss.)

- Un crucifijo de barro pequeño puesto en la cruz. 1774. Sequeros, inv. Mathías Prieto (Prot. 6251, f. 140v)

- una cruz de madera y sobre ella una efigie de Christo crucificado de Bronze pequeña. 1776. Sequeros, inv. Úrsula Muñoz (Prot. 6251, ff. 115 y ss.)

- Cruzifixo de yeso endido con su cruz de madera, 2 r. Id. otro destaño en 3. 1777. Sotoserrano. Inventario (Prot. 6313, f. 31)

- cruz de madera. 1780. Villanueva, inv. María Martín Cortes (Prot. 6324, ff. $1-4 v)$

- otro [quadrol mayor con un cruzifijo. 1782. Alberca, inv. Don Juan Santiago, Pbr. ${ }^{\circ}$ (Prot. 6120, f. 160)

- una cruz de madera con sus pinturas, 4rs. 1782. Miranda, inv. Magdalena Hernández (Prot. 6152, f. 151)

- una efixie de Cristo en alquimia, 2 rs. 1786. Miranda, inv. Antonio García (Prot. 6152, f. 151)

Advocaciones locales de CRISTO [(3), 1712-1758]

De la Luz [(1), 1712]

- quadro del Xt..$^{\circ}$ de la Luz. 1712. Candelario. Inventario (Prot. 1133, f. 54) ${ }^{66}$

Del Pardo [(1), 1729]

- un crucifijo del Pardo en una estampa. 1729. Cepeda. Inventario (Prot. 6000, f. $77 v$ )

Del Amparo [(1), 1758]

- quadro de figura del Cristo del amparo con su marco dorado, $6 r$. 1758. Sequeros, inv. Mariana Garzía Rubio. (Prot. 6247, ff. 45v y ss.) ${ }^{67}$

66 Debe tratarse del tan venerado en toda la región Cristo del Zarzoso.

67 Bajo esta advocación se conoce el Cristo del humilladero en Garcibuey y otro en la parroquial de San Esteban de la Sierra, pero nada hace suponer que hubiera de ellos estampas u otra hechura. 
El Sacramento [(2), 1712-1780]

- una estampa del Santísimo Sacramento. 1712. Candelario. Inventario (Prot. 1133, f. 54)

- yten un quadro viejo con la pintura del Santísimo Sacramento. 1780. Villanueva, inv. M. ${ }^{a}$ Martín Cortes (Prot. 6324, ff. 1-4v)

\section{ADVOCACIONES MARIANAS (85)}

DE CARÁCTER GENERAL (37)

Soledad [(12), 1701-1754]

- quadro de N. ${ }^{a} .^{a}$ de la Soledad. 1701. San Martín, inv. Boticario (Prot. 6194, f. 104)

- una Soledad. 1701. Sequeros, inv. Juan de la Guerta (Prot. 6237, f. 26)

- imaxen de $N^{a}{ }^{\text {S }}{ }^{a}$ de la Soledad con su marco. 1703. Sequeros, inv. Ana Hernández Berrocal (Prot. 6237, f. 47)

- un quadro de Balladolid de la Soledad. 1718. Miranda, inv. María de Tapia (Prot. 6144, f. 43v)

f. $97 v$ )

- una Soledad. 1726. Sequeros, tes. ${ }^{\circ}$ Angela Rodríguez (Prot. 6239,

- imagen de la Soledad, Pintura de Valladolid. 1738. Sequeros, inv. M. ${ }^{a}$ Anaya (Prot. 6241, f. 267v)

- cuadro de $N^{a}{ }^{a}{ }^{a}$ de la Soledad. 1740. Sequeros. Inventario (Prot. 6242, f. $190 \mathrm{v})$

- quadro de la Soledad. 1742. San Martín. Inventario (Prot. 6203, f. 38v)

- una Soledad. 1743. Alberca, matrimonio de Don Antonio Pies de la Guebra (Prot. 6106, f. 184)

- Pintura de la Soledad, 3 rs. 1743. Candelario, inv. Pedro Batanero (Prot. 1133, f. 29v)

- quadro biexo de la soledad, echura de Valladolid. 1745. Sequeros, inv. Antonio Martín Frayle (Prot. 6243, f. 137v)

- quadro de imagen de Soledad de Valladolid. 1749. Sequeros, inv. Antonio Hernández (Prot. 6244, f. 179-185)

- quadro de N. ${ }^{a}{ }^{a}$ de la Soledad de Pintura de Valladolid. 1754. Sequeros, inv. Juan Antonio Anaya (Prot. 6246, f. 164) ${ }^{68}$

Dolores [(3), 1761-1782]

- quadro de los Dolores, 4rs. 1761. Miranda. Inventario (Prot. 6165, f. 16v)

- estampa en papel de marca con los Dolores. 1780. San Martín. Inventario (Prot. 6207, fs. )

68 De las doce Soledades inventariadas, cinco al menos se confirman como de Valladolid; seguramente la tan difundida un siglo antes (1603) por Roelas, Virgen de las Angustias de Juni. 
- Un quadro de los Dolores, 4 rs. 1782. Candelario, inv. Alonso López (Prot. 1141, f. $20 \mathrm{ff}$ )

Carmen [(6), 1700-1783]

- imagen del Carmen en el aposento. 1700. San Martín. Inventario (Prot. 6194 , f. 242) ${ }^{69}$

- una vitela del Carmen. 1704. Sequeros, inv. Juana de Guerta (Prot. 6237, sf.)

- Quadro del Carmen, fábrica de Balladolid, 3. 1712. Candelario. Inventario (Prot. 1133, f. 54)

- dos efigies del Carmen [...] de yeso, 1 rl. 1777. Sotoserrano. Inventario (Prot. 6313, f. 31)

- Carmen de vulto $y$ de vierro [con otras seis de bulto, de santos, una de madera] 1783. San Martín. Inventario (Prot. 6207, f. 8)

Concepción [(8), 1736-1783]

- Imagen de la Conzepción de talla y dorada y estofada. 1736. San Martín. Inventario (Prot. 6202, f. 130v)

- quadro grande de la Conzepción con su marco, 26 rs. 1736. Sequeros, inv. de Santos de Frías en dote a Josepha de Borxa (Prot. 6240, f. 75v)

- conzepción con su marco. 1742. San Martín. Inventario (Prot 6203, f. $38 v$ )

- imagen de la concepción de vulto dorado con su cielo pintado. 1754. San Martín. Inventario (Prot. 6205, fs.)

- estampa grande de la Concepción y otra pequeña con medias cañas. 1771. Cepeda, inv. Joachín Bueno, Bfd." (Prot. 6010, ff. 157-162)

- estampa en papel de marca con una Concepción. 1780. San Martín. Inventario (Prot. 6207, f. 14)

- quadro grande de $N^{a} S^{a}$ de la Conzepción, 10 rs. 1783. Miranda, inv. Juan Hernández Tapia (Prot. 6152, f. 241) ${ }^{(1)}$

Candelaria [(1), 1782]

- quadro de la Candelaria, 4 r. 1782. Candelario, inv. de Alonso López (Prot. 1141, 20 fol. )

Consolación [(1), 1712]

- estampa de la Vingen de la Consolación. 1712. Candelario. Inventario (Prot. 1133, f. 54)

69 Único ejemplo donde se refleja la situación devocional doméstica que en este caso hemos de calificar como "de alcoban.

70 En cinco de los ocho casos inventariados de Concepciones, tanto pintadas como de bulto, parece se exigiera para esta advocación una tácita calidad. 


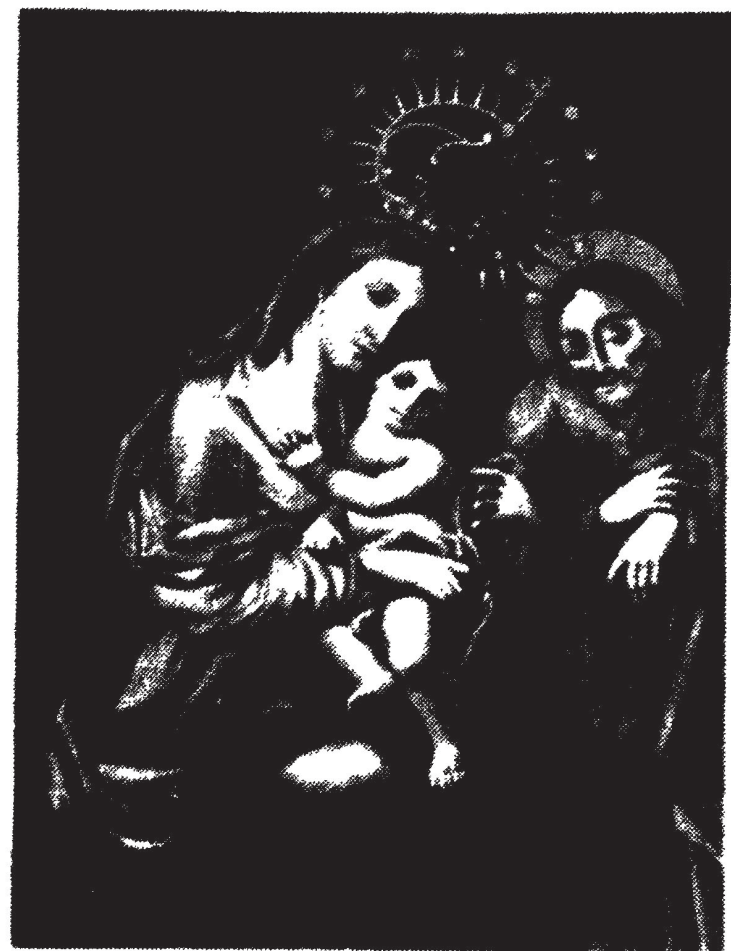

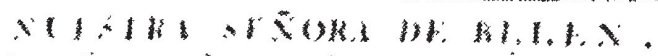

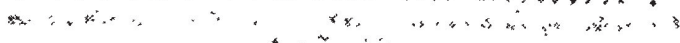

LÁM. XI-N.a S.a de Belén, copia de Murillo, que se venera en su retablo en la calle de Gallegos de Sevilla. (Grabado de José Manuel Martín, Madrid, año 1792. Col. part.).
Mercedes [(1), 1782]

- Un quadro de la Vingen de las Merzedes, 2 rs. 1782. Candelario, inv. Alonso López (Prot. 1141, 20 fol.)

Rosario [(5), 1726-1777]

- quadro de N. ${ }^{a} S^{a}$ del Rosario. 1726. Sequeros. Inventario (Prot. 6239, f. 85)

- Quadro de marco con el Retrato del Rosario, 9 rs. 1754. Alberca. Inventario (Prot. 6111, f. 19)

- Quadro de N. ${ }^{a} S^{a}$ del Rosario. 1759. Alberca. Inventario (Prot. 6113, f. 94v)

- estampa de papel de $N^{a} S^{a}$ del Rosario con su caña. 1765. Miranda, inv. Don Antonio Rodríguez de Ledesma, pbr. ${ }^{\circ}$ (Prot. 6148, ff. 3 y ss.)

- efigie del Rosario de yeso, 1 $r l$. 1777. Sotoserrano. Inventario (Prot. 6313, f. 31)

\section{PARTICUIARES O TOPOGRÁFICAS (24)}

Atocha [(1), 1782]

- quadro de Atocha. 1782. San Martín. Inventario (Prot. 6207, fs.)

Belén [(4), 1701-1765]

- Una Nuestra Señora de Belén. 1701. Sequeros, inv. Juan de la Guerta (Prot. 6237, f. 26)

- quadro mayorcito de Nuestra Señora de Belén. 1710. Cepeda. Inventario (Prot. 5999, f. 170v)

- quadro grande con su marco de $N^{a}{ }^{a}{ }^{a}$ de Belén, no se le dio tasa por dexarlo al Robledo. 1733. Sequeros, inv. lcd. ${ }^{\circ}$ Don Miguel Pozo, pbr. (Prot. 6240 , f. $69 \mathrm{v}$ )

- un quadro de $N^{a}{ }^{a} .^{a}$ de Belén. 1765. Miranda, inv. Don Antonio Rodríguez de Ledesma, pbr. ${ }^{0}$ (Prot. 6148, ff. 3 y ss.) ${ }^{71}$

71 Nuestra Señora de Belén tenía por entonces monasterio en el término de la Herguijuela. Desconocemos si se extendieron desde allí representaciones pintadas o 
Camino [(1), 1785]

- estampa de tafetán pagizo de $N^{a}{ }^{a} .^{a}$ del Camino. 1785. Cepeda, inv. Sebastián Blanco (Prot. 6014, ff. 148 y ss.)

Castillo [(1), 1704]

- estampa de $N^{a}{ }^{a} .^{a}$ del Castillo. 1704. Sequeros, inv. Juana de Guerta (Prot. 6237, f. ff. 39 y ss.)

Desamparados [(1), 1749]

- $N^{a} S^{a}$ de los Desamparados con su marco. 1749. Sequeros. Inventario (Prot. 6244, f. 197)

Francia [(7), 1704-1782]

- una estampa de $N^{a} S^{a}$ de Franzia. 1704. Sequeros, inv. Juana de Guerta (Prot. 6237, ff. 39 y ss.)

- una imagen de la Peña de Franzia. 1706. Sequeros, inv, Martina Hernández (Prot. 6237, f. 28v)

- un quadro de Franzia [Nuestra Señora o tema francés ¿ ?] 1744. Cepeda. Inventario (Prot. 6003, f. 88)

- echura de la Peña con su caxa. 1748. Alberca, inv. Juan López Viexo (Prot. 6108, f. 30v)

- quadro de N. ${ }^{a}$ S. ${ }^{a}$ de la Peña. 1753. Sequeros, inv. Juan de Huerta (Prot. 6245, f. 126)

- un quadro de Francia [¿de Nuestra Señora o francés?] 1782. San Martín. Inventario (Prot. 6207, fs.)

- quadro de la Vingen de Franzia. 1782. Candelario, inv. Alonso López (Prot. 1141, sf.)

Illescas o Caridad [(1), 1704]

- estampa de N. ${ }^{a} S^{a}$ de Illescas. 1704. Sequeros, inv. Juana de Guerta (Prot. 6237, ff. 39 y ss.)

Leche [(1), 1715]

- Lámina de $N^{a} S^{a}$ de la Leche de cobre. 1715. Miranda, inv. Jerónimo Rodríguez de Ledesma, escribano (Prot. 6144, ff. 51 y ss.) ${ }^{72}$

Pilar [(1), 1742]

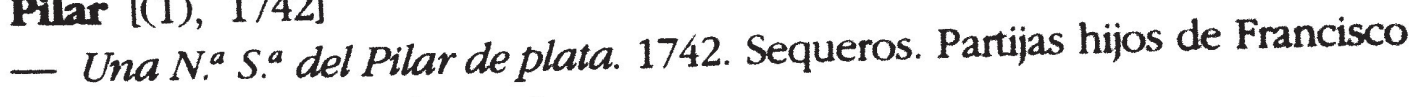
Diez (Prot. 6243, ff. 196 y ss.)

impresas de la imagen, aunque esta iconografia apenas presenta variaciones locales sino es en la guarnición.

72 Don Jerónimo Rodríguez de Ledesma aparece compartiendo escribanía con Don Gregorio Díez Barrio en protocolos desde 1708 a 1718 (Prot. 6144) y debió morir en el año quince, siguiendo luego Gregorio solo. 


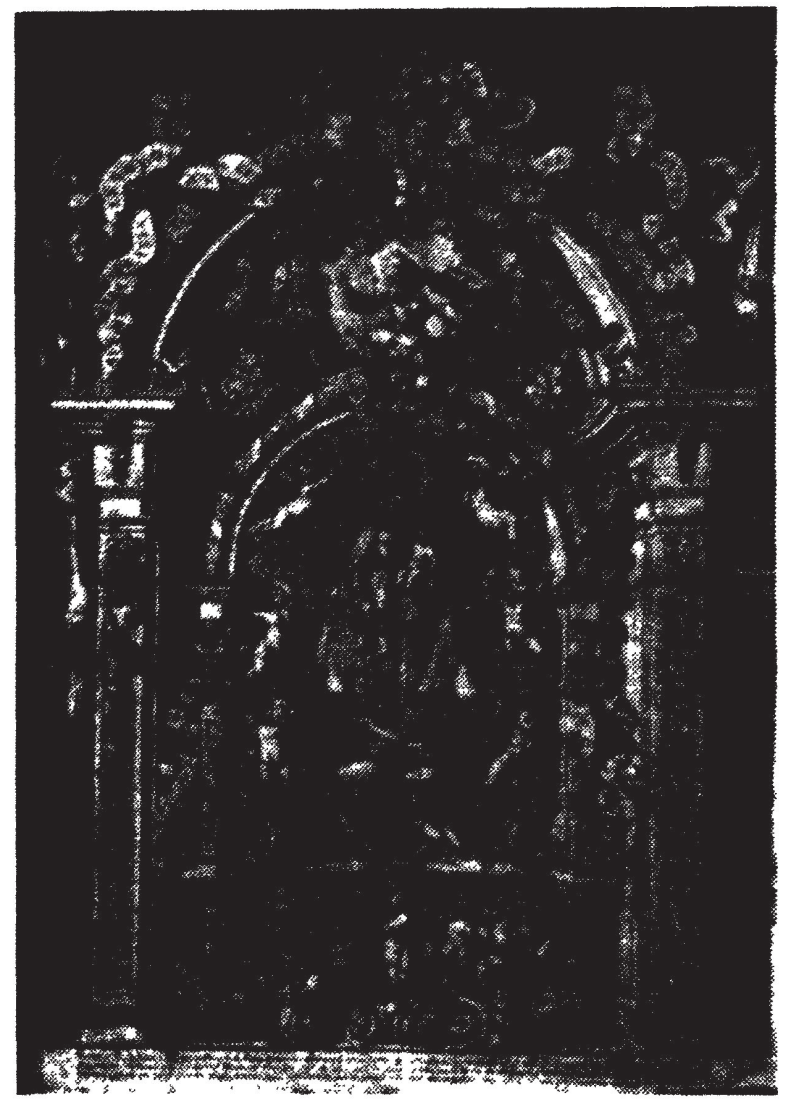

LÁM. XII.-N. ${ }^{a}$ S. ${ }^{a}$ del Rosario de San Esteban de Salamanca, aspecto en cuias prendas piadosamente suele representarse su majestad soberana con singular propiedad en esta graciosissima Imagen. Grabado de A. van Westerhout, Roma, c. 1720 (Toro, M. ${ }^{\circ}$ de Sancti Spiritus. Foto de Javier Vila).
Pópulo [(2), 1704-1722]

- una imagen pequeña del Pópulo en quadro. 1704. Cepeda, inv. Juan González, Herrador (Prot. 5997, f. 99v)

- caxa con imagen de $N^{a} S^{a}{ }^{a}$ del Pópulo. 1722. San Martín. Inventario (Prot. 6198, f. 91v)

\section{Remedios (¿de Salamanca?)} [(1), 1705]

- Lámina nueba de $N^{a} .^{a}{ }^{a}$ de los Remedios. 1705. Sequeros, inv. Agustina Rodríguez (Prot. 6237, f. $37 v)^{73}$

\section{Risco [(1, 1704]}

- Estampa de N. ${ }^{a} S^{a}$ del Risco. 1704. Sequeros, inv. Juana de Guerta (Prot. 6237, ff. 39 y ss.)

Robledo [(1), 1706]

- un quadro de $N .^{a} S^{a}$ del Robledo con su marco. 1706. Sequeros, inv. lcd. ${ }^{\circ}$ Juan Rodríguez de Tapia (Prot. 6237, f. 12)

\section{Rosario de San Esteban de Salamanca [(1), 1725]}

- Una imaxen de $N^{a} .^{a}{ }^{a}$ del Rosario de San Esteban de Salamanca, pintada en papel. 1725. San Martín. Inventario (Prot. 6199, f. 124v) ${ }^{74}$

73 Sería la muy venerada en la parroquia salmantina de San Julián, a quien por estos años era costumbre hacer manda de misas de ánima en testamento.

74 Esta imagen que está "vestida de gracia" (tallada) fue regalo de S. S. Pio V a los Dominicos de San Esteban, donde se venera en altar propio en el crucero y lado del evangelio. Conservan las Dominicas de Sancti Spiritus en el zaguán de su monasterio de Toro un grabado de esta advocación, obra de Arnold Van Westerhout, en cuyo pie se lee: .Arnold [...] Sculp. romae, sup. Perm". Este pintor y grabador (1651 Antwerpen, †1725 Roma) reprodujo en su época romana temas de diversas Órdenes Religiosas sobre pintura de A. Carraci, Domenichino, Rafael y Tiziano entre otros. Para la nuestra tuvo que ver también en Roma la obra pintada que, con las licencias oportunas, tomó como modelo. Desconocemos el grado de presión a que se vería sometido el pintor cuyo nombre se omite en el grabado, para pasar al lienzo esta imagen, que ya se presentaba entonces como *vestidera", ajustándose estrictamente al concepto de lo que se entiende por 
De Nuestra Señora sin especificar [(20), 1703-1782]

- Ocbo estampas de $N^{a} S^{a}{ }^{a} 1703$. Cepeda. Inventario (Prot. 5996, f. 120)

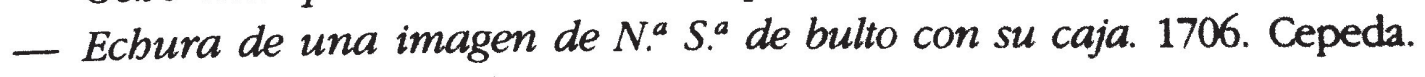
Inventario (Prot. 5998, f. 94)

- N. ${ }^{a}$ S $^{a}$ de bulto co su peana. 1715. Miranda, inv. Don Jerónimo Rodríguez de Ledesma y San Miguel, escribano (Prot. 6144, ff. 51 y ss.)

- quadro con N. $.^{a} .^{a}$ y el Niño. 1726. Sequeros, test. ${ }^{\circ}$ Angela Rodríguez (Prot. 6239, f. 97v)

- lámina en chapa de Maria. 1742. San Martín. Inventario (Prot. 6203,

\section{f. $38 v$ )}

- pintura de $N^{a} S^{a} y$ del Niño, con marco y tarjeta dorada, de media vara, 30 rs. Pintura de $N^{a} S^{a}{ }^{a}$ con el Niño, marco dorado, 40 r. 1742. Sequeros, partijas de los hijos de Don Francisco Díez (Prot. 6243, ff. 196 y ss.)

- Mando a $N^{a} S^{a}$ del Robledo una $N^{a} .^{a} .^{a}$ que tengo de bulto. 1745. Miranda, test..$^{\circ}$ Bfd. $^{\circ}$ del Robledo Don Francisco Sánchez Tapia (Prot. 6146, sf.)

- una Ymagen de $N^{a}{ }^{a}{ }^{a}$ con vestido de raso azul y mandelete de tafetán encarnado con un encaje de Milán. 1748. Sequeros. Inventario (Prot. 6244, f. 21)

- Una imaxen de la Virgen de escultura. 1749. Sequeros, inv. Antonio Hernández (Prot. 6244, ff. 179-185)

- Una imagen de $N^{a} S^{a}{ }^{a}$ de yeso. 1764. Sequeros, inv. Agustina González, vd. ${ }^{a}$ de Francisco Berrocal (Prot. 6248, f. 6)

- una imagen de $N^{a} S^{a}$ de bulto en 16 rs. 1771. Miranda. Inventario (Prot. 6149, f. 348)

- quadro de N. $.^{a} .^{a}$ y Niño en los brazos. 1782. San Martín (Prot. 6207, fs.)

Medidas [(4), 1702-1742]

Francia [(4), 1702-1742]

- una medida de Franzia viexa. 1702. Cepeda, inv. Ana Sánchez (Prot. 5996, ff. 69-70v)

- dos medidas doradas de Franzia. 1725. San Martín. Inventario (Prot. 6199 , ff. 102v)

- una medida de $N^{a} S^{a}$ de Franzia pagiza. 1742. Sequeros, inv. Joachín Rodríguez (Prot. 6243, ff. 266 y ss.)

"verdadero retrato" y no reinterpretándola, como era habitual, con libertad. En la Sierra esta imagen se difundió con más éxito, embutida en joyas-relicario, cuyas variantes (redondas, ovaladas, esquinadas y en ochavo) tenían ya las estampas adaptadas al relicario, con solo el rostro y rostrillo de María, mas la leyenda de su advocación a manera de guirnalda. Algunos de estos ejemplos van iluminados a la morisca y con guarnición de lentejuelas de clavo. 
IV. SANTORAL (169)

SANTAS (41)

Agueda [(1), 1709]

- Santa Agueda sin marco. 1709. Cepeda, inv. Francisco Díez Barrio (Prot. 5996, f. 590) ${ }^{75}$

Ana [(4), 1710-1772]

- San Francisco y Santa Ana [en una caja a los lados de un crucifijo] de bulto. 1710. Miranda, inv. Isavel Cascón (Prot. 6144, f. 17v)

- quadro de Santa Ana. 1754. Sequeros, inv. Juan Antonio Anaya (Prot. 6246, f. 164)

- una Santa Ana de lo mismo [yeso] quebrada. 1764. Sequeros, inv. María Martín (Prot. 6248, f. 31)

- Dos efixies de Santa Ana y Santa Bárbara de yeso. 1772. Villanueva, dote de Isabel Sanz (Prot. 6322, sf.)

Apolonia [(1), 1718]

- quadro de Santa Polonia. 1718. Miranda, inv. María de Tapia (Prot. 6144 , f. 43)

Bärbara [(4), 1772-1782]

- dos efixies de Santa Ana y Santa Bárbara de yeso. 1772. Villanueva, dote de Isabel Sanz (Prot. 6322, sf.)

- estampa en papel de marca con una Santa Bárbara. 1780. San Martín. Inventario (Prot. 6207, f. 14)

- quadrito de Santa Bárbara 1 rl. 1782. Candelario, inv. Alonso López (Prot. 1141, 20 fol.)

- Santa Várbara de vulto y de yerro. 1783. San Martín. Inventario (Prot. 6207 , f. 8)

Catalina [(4), 1706-1776]

f. 94)

- quadro con Santa Catalina viejo. 1706. Cepeda. Inventario (Prot. 5998,

- quadro de Santa Catharina en papel y marco negro. 1736. San Martín. Inventario (Prot. 6202, f. 130v)

- quadro de Santa Catalina con marco en blanco, $30 \mathrm{rs}$. Sequeros, inv. Mariana Garzía Rubio (Prot. 6247, ff. 45v y ss.)

- un quadro de Angéo con su marco de madera y estampado en él una Santa Catalina, 8 rs. 1776. Sequeros, inv. Joseph Palomino (Prot. 6251, s.f.)

7 Francisco Díez Barrio ejerció como escribano en Cepeda durante los años 1701 a 1708 (protocolos 5996-5998). 
Clara [(1), 1754]

- quadro de Santa Clara. 1754. Sequeros, inv. Juan Antonio Anaya (Prot. 6246, f. 164)

Inés [(1), 1706]

- otro quadro de Santa Inés. 1706. Cepeda. Inventario (Prot. 5998, f. 96)

Justa [(1), 1782]

- quadro de Santa Justa. 1782. Candelario, inv. Alonso López (Prot. 1141, 20 fol.)

Lucia [(1), 1712]

- Quadro de Santa Lucia. 1712. Candelario. Inventario (Prot. 1133, f. 54)

M." Magdalena [(6), 1704-1743]

- quadro de una Madalena. 1704. Sequeros, inv. Juana de Guerta (Prot. 6237, ff. 39 y ss.)

- quadro de la magdalena, 4rs. 1705. Candelario. Inventario (Prot. 1132, f. 23)

- quadro de un San Juan y Magdalena. [icamino del Calvario?] 1709. Cepeda, inv. Francisco Díez Barrio, Essn. ${ }^{\circ}$ Público (Prot. 5999, f. 59v)

f. 54)

- Quadro de la Magdalena. 1712. Candelario. Inventario (Prot. 1133,

- Una pintura de la Magdalena. 1742. Sequeros, inv. Diez Zúñiga y Palomeque (Prot. 6243, f. 205)

- una Madalena. 1743. Alberca, matrimonio de Ana Pies de la Guebra (Prot. 6106, f. 184) ${ }^{76}$

Rita [(1), 1749]

- Lámina de Santa Rita. 1749. Sequeros. Inventario (Prot. 6244, f. 196) Rosa [(3), 1726-1764]

- otro quadro de Santa Rosa. 1726. Sequeros, test. ${ }^{\circ}$ Ángela Rodríguez (Prot. 6239, f. 97v)

- quadro grande que tiene una Santa Rosa, 15 rs. 1761. Miranda, inv. M. $^{a}$ de Tapia (Prot. 6165, f. 16v)

- quadro de Santa Rosa. 1764. Sequeros, inv. Agustina González, vd. de Francisco Berrocal (Prot. 6248, f. 6)

76 Debe tratarse en estos ejemplos de la Magdalena Penitente, salvo en el que se hace acompañar por Juan Evangelista (Cepeda, 1709). Esta pareja llegando deprisa a la Calle de la Amargura para ver a Cristo camino del Calvario, fue muy popular en pintura y no menos divulgada a través de romances de la Pasión. Familiaridad iconográfica que dio pie, luego, a cancioncillas de carácter grotesco y contenido disparatado como la que empieza: San Juan y la Magdalena fueron juntos a melones, San Juan en el melonar, San Juan rompió los calzones. 
Teresa [(14), 1700-1783]

- un quadrito de Santa Teresa en los $6 r$ s. de su tasa. 1700. Sequeros, inv. Isavel Pérez de Jacinto Garzía (Prot. 6235, f. 38v)

- echura de Santa Teresa de barro. 1704. Cepeda. Inventario (Prot. 5997, f. $329 \mathrm{v})$

- otro quadro de Santa Teresa de Jesús. 1704. Sequeros, inv. Jacinta de Guerta (Prot. 6237, ff. 39 y ss.)

- otro quadro de Santa Theresa, 4 rs. 1705. Candelario. Inventario (Prot. 1132, f. 23)

- otro quadro de Santa Teresa. 1706. Sequeros, inv. Lcd. ${ }^{\circ}$ Rodríguez de Tapia (Prot. 6237, f. 12)

- quadro de Santa Teresa sin marco. 1711. Cepeda, inv. lcd..$^{\circ}$ Fc. ${ }^{\circ}$ Blanco (Prot. 5999, ff. 30-32)

- dos Santas teresas de barro, guarnecidas de mano de monxas. 1718. Miranda, inv. Jerónimo Gutiérrez (Prot. 6144 f. 37v)

- otro [quadrol viejo de Santa Teresa, 7 rs. 1726. Sequeros, test. ${ }^{\circ}$ Ángela Rodríguez (Prot. 6239, f. 97v)

- quadro pequeñito de Santa Teresa, con marco negro. 1736. San Martín. Inventario (Prot. 6202 f. 130v)

- Pintura de Santa Teresa de Jesús con marco negro y tarjetas doradas. 1742. Sequeros, partijas hijos de Francisco Díez (Prot. 6243 ff. 196 y ss.)

- Estampa de Santa Teresa, el marco de ébano. 1765. Miranda, inv. Antonio Rodríguez de Ledesma, Presvítero (Prot. 6148, ff. 3 y ss.)

- quadro de Santa Teresa. 1782. San Martín. Inventario (Prot. 6207 fs.)

- una Santa Teresa de vulto y de yerro. 1783. San Martín. Inventario (6207, f. 8)

\section{SANTOS [123]}

Apóstoles [(12), 1782]

- doze quadros de los doze apóstoles. 1782. Alberca, inv. D. Juan Santiago, Pbr. $^{\circ}$ (Prot. 6120, f. 16v)

Agustin [(3), 1705-1783)

- echura de San Agustín. 1705. Sequeros, inv. Juan Rodríguez Roque (Prot. 6237, f. 9)

- quadro pequeño y biejo [...] de San Agustín. 1774. Sequeros, inv. Mathías Prieto (Prot. 6251, f. 140v)

- un quadro grande con su marco que es un San Agustín. 1783. San Martín. Inventario (Prot. 6207, f. 8)

Alfonso [(1), 1701]

- quadro de San Alfonso. 1701. San Martín. Inventario (Prot. 6194, f. 165) 
Amador [(1), 1785]

- estampa con la efigie de San Amador. 1785. Cepeda, inv. Sebastián Blanco (Prot. 6014, ff. 148 y ss.) ${ }^{\top 7}$

Amoroso [(1), 1783]

- otro lquadrol grande con un San Amoroso. 1783. San Martín. Inventario (Prot. 6207, f. 8)

Ángel de la Guarda [(3), 1704-1748]

- un quadro del Angel de la Guarda. 1704. Cepeda, inv. Juan González, Herrador (Prot. 5997, f. 99v)

- Quadro del Angel de la Guarda. 1712. Candelario. Inventario (Prot. 1133, f. 54)

- un quadro del Santo Angel de la Guarda con su marco. 1748. Alberca, inv. Juan López Viexo (Prot. 6108, f. 30v)

Antonio [(11), 1701-1773]

f. 104)

- quadro de San Antonio. 1701. San Martín, inv. Boticario (Prot. 6194,

- un quadro grande de San Antonio. 1715. Sequeros. Inventario (Prot. 6238, f. 35)

- otro quadro de San Pablo y San Antonio. 1742. San Martín. Inventario (Prot. 6203, f. 38v)

- quadro de San Antonio viexo, echura de Sebilla. 1745. Sequeros, inv. Antonio Martín Frayle (6252, f. 210)

- Un San Antonio de Vulto con su cagita pequeña. 1747. Miranda, inv. Juan de la Peña (Prot. 6164, f. 11)

- Un San antonio de barro, 5 rs. 1758. Sequeros, inv. Mariana Garzía Rubio (Prot. 6247, f. 45v y ss.)

- San Antonio con su caja en 60 rs. 1761. Miranda. Inventario (Prot. 6165, f. 16v)

- San Antonio de Barro. 1771. Cepeda, inv. Joachín Bueno, Bfd." de Cepeda (Prot. 6010, ff. 157-162)

- San Antonio Avad de bulto. 1783. San Martín. Inventario (Prot. 6207, f. 8)

- echura de bulto de San Antonio pequeña. 1789. Monforte. Inventario (Prot. 6182, f. 25v)

- quadrito de San Antonio de yeso 1 real. 1773. Sotoserrano, inv. Mathías Sánchez, alcalde (Prot. 6312, s.f.)

$\pi$ La costumbre de dejar mandadas en testamento misas conocidas como de San "Amador", supone hacia este santo una devoción arraigada, aunque solo contemos con un único ejemplo en que su imagen se representara. Desconocemos si el San Amoroso que viene detrás puede ser una corruptela de aquél. 
Antonio de Padua [(4), 1704-1782]

- quadro de San Antonio de Padua. 1704. Sequeros, inv. Juana de la Guerta (Prot. 6237, ff. 39 y ss.)

- imagen de bulto de San Antonio de Padua. 1715. Miranda, inv. Jerónimo Rodríguez de Ledesma, essn. ${ }^{\circ}$ (Prot. 6144, f. 51 y ss.)

- Pintura de San Antonio de Padua, 3 rs. 1743. Candelario, inv. Pedro Batanero (Prot. 1133, f. 29v)

- un quadro de San Antonio de Padua, 4 rs. 1782. Candelario, inv. Alonso López (Prot. 1141, 20 fol.)

Bernardo [(2), 1722-1783]

- quadro de San Bernardo [...J 1722. Arroyomuerto, en escritura de San Martín, inv. Bastida, zerero (Prot. 6198, f. 40)

- otro lquadrol con San Bernardo. 1783. San Martín. Inventario (Prot. 6207, f. 8)

Cayetano [(1), 1712] f. 54)

- Quadro de San Caietano. 1712. Candelario. Inventario (Prot. 1133,

Claudio [(1), 1743]

- pintura de San Claudio, 4 rs. 1743. Candelario, inv. Pedro Batanero (Prot. 1133, f. 29v)

Diego de Melania [(1), 1736]

- quadro de San Diego de Melania. 1736. San Martín. Inventario (Prot. 6202, f. 130v)

Domingo [(4), 1736-1742]

- imagen de Santo Domingo y N. $.^{a} .^{a}$ 1736. San Martín. (Ibid)

- quadro de San Pedro y Santo Domingo, 10 rs. 1738. Sequeros, hijuela de M. García (Prot. 6241, f. 392v)

- cuadros de Santo Domingo [...J 1740. Sequeros. Inventario (Prot. 6242, f. $190 \mathrm{v}$ )

- Dos láminas de Santo Domigo y San FC. ${ }^{\circ}$, pintadas en vidrio con marcos dorados y una quarta, 30 rs. 1742. Sequeros, partija, hijos de Francisco Díez (Prot. 6243 ff. 196 y ss.)

Félix Cantalicio [(1), 1743]

- pintura de San Félix de Cantalizio, 3 rs. 1743. Candelario, inv. Pedro Batanero (Prot. 1133, f. 29v)

Francisco [(11), 1710-1777)

- San Francisco y Santa Ana len caja, a los lados de un Crucifijol de bulto. 1710. Miranda, inv. Isavel Cascón (Prot. 6144, f. 17v) 
- San Francisco y Cristo. 1712. Candelario. Inventario (Prot. 1133, f. 54)

- l..J una echura de un San Francisco. 1719. Cepeda. Inventario (Prot. 6903, f. 106v)

- [quadrol de San Francisco. 1722. Arroyomuerto, en escritura de San Martín, inv. Bastida, Zerero (Prot. 6198, f. 40)

- quadro de San Francisco, 5 rs. 1726. Sequeros, test. ${ }^{\circ}$ Ángela Rodríguez (Prot. 6239, ff. 97v)

- echura de San Francisco con su caxa. 1748. Alberca, inv. Juan López Viexo (Prot. 6108, f. 30v)

- un quadro de Cruzifijo y San Francisco, 3 rs. 1754. Alberca. Inventario (Prot. 6111, ff. 59)

- un quadro de San Francisco. 1755. Monforte. Inventario (Prot. 6177, f. 98)

- quadro de San Francisco de Asís, con marco sin dorar, 70 rs. 1758. Sequeros, inv. Mariana Garzía Rubio (Prot. 6247, ff. 45v y ss.)

- echura de un San Francisco con su marco dorado. 1764. Sequeros, inv. Agustina González, vd. ${ }^{a}$ de Francisco Berrocal (Prot. 6248, f. 6)

- urna de seda con efixie pequeña de San Francisco, con seis reliquias. 1777. Sequeros, inv. Pedro Regalado García (Prot. 6252, f. 210)

Francisco de Borja [(1), 1704]

- quadro de San Francisco de Borxa. 1704. Sequeros, inv. Juana de Guerta (Prot. 6237, ff. 39 y ss.)

Francisco Caraciolo [(1), 1743]

- Pintura del Venerable Padre Francisco Caraziolo en 11 rs. 1743. Candelario, inv. Pedro Batanero (Prot. 1133 f. 29v)

Francisco Javier [(2), 1742-1743]

- Un San Francisco Xavier, con marco negro y tarjetas doradas, de vara $y$ terzia, 60 rs. 1742. Sequeros, partijas hijos Francisco Díez (Prot. 6243, ff. 196 y ss.)

- estampa de San Francisco Jabier, 2 rs. 1743. Candelario, inv. Pedro Batanero (Prot. 1133, f. 29v)

Gabriel Arcángel [(1), 1749]

- un quadro de San Gabriel en una estampa. 1749. Sequeros. Inventario (Prot 6244, f. 196)

Indefonso [(1), 1711]

- quadro de San Ildefonso de la fábrica de Balladolid. 1711. Candelario. Inventario (Prot. 1133, f. 59)

Jerónimo [(2), 1715-1742]

- una echura, de talla de San Jerónimo con su marco dorado. 1715. Sequeros. Inventario (Prot. 6238, f. 35) 
- San Jerónimo en un quadro grande de pintura fina con su marco con molduras doradas. 1742. San Martín. Inventario (Prot. 6203, f. 38v)

José [(5), 1701-1764]

- quadro de San Joseph, con su marco dorado. 1701. San Martín, inv. Pedro Batanero (Prot. 6194, f. 104)

- quadro de San Joseph. 1712. Candelario. Inventario (Prot. 1133, f. 54) f. $16 \mathrm{v}$ )

- quadro de San Joseph, 2 rs. 1761. Miranda. Inventario (Prot. 6165,

- echura de San Joseph de yeso. 1764. Sequeros, inv. Agustina González, vd.a de Francisco Berrocal (Prot. 6248, f. 6)

- un San Joseph de yeso. 1764. Sequeros, inv. María Martín (Prot. 6248, f. 31)

Juan Bautista (y Degollado) [(15), 1701-1783]

- dos quadros de San Juan pequeños. 1701. San Martín, inv. Boticario (Prot. 6194, f. 104)

- quadro de San Juan. 1704. Sequeros, inv. Juana de Guerta (Prot. 6237, ff. 39 y ss.)

- quadro del Señor San Juan. 1704. Cepeda, inv. Juan González, Herrador (Prot. 5997, f. 99v)

- un quadro de San Juan. 1706. Cepeda. Inventario (Prot. 5998, f. 96)

- otros dos quadros mayorcitos de San Juan y Belén. 1710. Cepeda, dote de Mariana Gallardo (Prot. 5999, f. 170v)

- quadro de San Juan. 1712. Candelario. Inventario (Prot. 1133, f. 54)

- quadro de San Juan. 1719. Cepeda. Inventario (Prot. 6903, f. 106v)

- otro lquadrol de San Juan en papel. 1736. San Martín. Inventario (Prot. 6202, f. 130v)

- otro [quadrol de la efigie de San Juan. 1742. San Martín. Inventario (Prot. 6203, f. 9v)

- un San Juan de zera, con marco negro. 1742. Sequeros, partijas, hijos de Francisco Díez (Prot. 6243 ff. 196 y ss.) ${ }^{78}$

- otro [quadrol de la cabeza de San Juan Bautista. 1742. San Martín. Inventario $(6203$, f. $38 \mathrm{v})$

f. $16 v$ )

- otro quadro de San Juan, 2 rs. 1761. Miranda. Inventario (Prot. 6165,

- quadro de San Juan. 1764. Sequeros, inv. Agustina González, vd. ${ }^{a}$ de Francisco Berrocal (Prot. 6248, f. 6) ${ }^{79}$

78 Vuelve a repetirse de nuevo con San Jan Bautista (en el siglo xvil en Cepeda y ahora en Sequeros), el único testimonio de hechura en cera.

79 Francisco Berrocal se registra como escribano en Sequeros de 1739 a 1763 (Protocolos 6242-6247). 
- quadro de San Juan degollado. 1783. San Martín. Inventario (Prot. 6207 , f. 8) [ver en II, p. 250 y nota 59, los Juanes que aparecen en Sagrada Familia] ${ }^{80}$

Juan Evangelista [¿Camino del Calvario?] [(1), 1709]

- un quadro y marco de San Juan y Magdalena. 1709. Cepeda, inv. Francisco Díez Barrio, Escribano Público (Prot. 5999, f. 59v)

Juan de la Cruz [(1), 1742]

- quadrito de San Juan de la Cruz. 1742. San Martín. Inventario (Prot. 6203 , f. 9v)

Juan de Sahagún [(2), 1704-1742]

- estampa de San Juan de Sahagún. 1704. Sequeros, inv. Juana de Guerta (Prot. 6237, ff. 39 y ss.)

- Pintura de San Juan de Sabagún con marco negro y tarjeta dorada, 60 rs. 1742. Sequeros, partijas hijos Francisco Diez (Prot. 6243, ff. 196 y ss.)

$\operatorname{Marcos}[(1), 1711]$

- quadro de San Marcos sin dorar. 1711. Cepeda, inv. Lcd. ${ }^{\circ}$ Francisco Blanco (Prot. 5999, ff. 30-32)

\section{Miguel Arcángel [(7), 1706-1782]}

- quadro del arcángel San Miguel con su bastidor. 1706. Sequeros, inv. Lcd. ${ }^{\circ}$ Rodríguez de Tapia (Prot. 6237, f. 12)

- estampa de San Miguel, 2 rs. 1743. Candelario, inv. Pedro Batanero (Prot. 1133, f. 29v)

- quadro de San Miguel con marco negro, 60 rs. 1758. Sequeros, inv. Mariana Garzía Rubio (Prot. 6247, ff. 45v y ss.)

- quadro de San Miguel, 2 rs. 1761. Miranda. Inventario (Prot. 6165, f. $16 \mathrm{v})$

- estampa con un San Miguel y quadrito pintura de San Miguel, 3 /rs.J 1780. San Martín. Inventario (Prot. 6207, f. 14)

- un quadro de San Miguel. 4 rs. 1782. Candelario, inv. Alonso López (Prot. 1141, 20 fol.)

Norberto [(1), 1745]

- Lámina de San Norberto. 1745. Miranda, test.", Bfd." del Robledo Don Francisco Sánchez (Prot. 6146, s.f.)

81 El gusto por el realismo exagerado, del que tan buenos ejemplos dio la escuela de Valladolid y a lo que sin parangón se prestaba la cabeza del Bautista sobre la bandeja, favorecería su divulgación en estampas y cuadros, procedentes quizá también de la calle de Santiago, en esa ciudad, si bien en estos inventarios nada se señala. 
Pablo [(1), 1740]

- cuadro de San Pablo [no sabemos si se refiere al apóstol]. 1740. Sequeros. Inventario (Prot. 6242, f. 190v)

Pablo Ermitaño [(1), 1742]

- otro [quadro] de San Pablo y San Antonio. 1742. San Martín. Inventario (Prot. 6203, f. 38v)

Santos ermitaños [(8), 1715]

- ocbo diferentes santos ermitaños. 1715. Miranda, inv. Don Jerónimo Rodríguez de Ledesma, essn. ${ }^{\circ}$ (Prot. 6144, ff. 51 y ss.)

Pedro [(5), 1712-1783]

- Quadro de San Pedro, fábrica de Balladolid, 3 rs. 1712. Candelario. Inventario (Prot. 1133, f. 54)

- un quadro viejo de San Pedro, 1 rl. 1713. Candelario. Inventario (Prot. 1133, f. 23)

- quadro de San Pedro y Santo Domingo, 10 rs. 1738. Sequeros. hijuela de M. ${ }^{2}$ García (Prot. 6241, f. 392v)

- quadro de San Pedro Apóstol. 1782. San Martín. Inventario (Prot. 6207, f.s.)

- un San Pedro [...J de vulto y de yerro. It. otro lquadro con San Pedro. 1783. San Martín. Inventario (Prot. 6207, f. 8)

Ramón Nonato [(1), 1782]

- quadro de San Ramón nonato. 1782. San Martín. Inventario (Prot. 6207, f.s.)

Santiago [(6), 1704-1774]

- estampa de Santiago. 1704. Sequeros, inv. Juana de Guerta (Prot. 6237, ff. 39 y ss.)

- dos echuras del Señor Santiago lademás de las de un santo Cristo y Soledad] todas de azabache fino. 1705. Sequeros, inv. Juan Rodríguez Roque (Prot. 6237, f. 9)

- Quadro de Santiago. 1712. Candelario. Inventario (Prot. 1133, f. 54)

- quadro del Señor Santiago. Pintura de Valladolid. 1738. Sequeros, inv. Santiago Martín (Prot. 6241, f. 267v)

- dos quadros pequeños y biejos, uno de Santiago y otro de San Agustín. 1774. Sequeros, inv. Mathías Prieto (Prot. 6251, f. 140v)

Sebastiā́n [(1), 1783]

- Un San Sebastián en bulto, es de madera. 1783. San Martín. Inventario (Prot. 6207, f. 8) 
Tomás [(2), 1736-1782]

- quadro de Santo Tomás y Nuestra Señora en tabla y marco por dorar. 1736. San Martín. Inventario (Prot. 6202, f. 130v) ${ }^{81}$

- otro [quadrol de Santo Tomás. 1782. Alberca, inv. Don Juan Santiago, Pbr. ${ }^{\circ}$ (Prot. 6120, f. 16v)

Santos sin identificar [(5), 1771-1774]

- una caja pequeña con unas imagines. 1771. Miranda. Inventario (Prot. 6149, f. 138)

- cuatro pinturas de Santos en Madera, cada una 4 rs. 1774. Sequeros, inv. Mathías Prieto (Prot. 6251, f. 140v) ${ }^{82}$

V. Temas del alma o postrimerías

Las cuatro (o tres) ánimas [(1), 1706]

- Una pintura de un condenado, con su bastidor. 1706. Sequeros, inv. Lzd. Juan Rodríguez de Tapia (Prot. 6237, f. 12]

VI. El País [(1), 1701]

- un Paisito. 1701. San Martín, inv. Boticario (Prot. 6194, f. 104)

Pais de caza [no hay ejemplos]

VII. EL BODEGÓN [no hay ejemplos]

VIII. Temas mitológicos, alegorías y emblemas (1)

El triunfo de la Iglesia [(1), 1742]

- Pintura del triumpho de la Yglesia. 1742. Sequeros, partijas hijos de Francisco Díez (Prot. 6243, ff. 196 y ss.) ${ }^{83}$

IX. El RETRATO [(2), 1759-1782]

- un retrato de Juan Fernández del Tablado. 1759. Alberca. Inventario (Prot. 6113, f. 94v) ${ }^{84}$

${ }^{81}$ Extraña esta referencia María-Tomás. Si se trata del apóstol creemos que estaría relacionado con el pasaje de la Dormición y cumpliendo, al menos en teatro, papel de gracioso que siempre llega tarde. Aunque estuviera destacada su figura formaba sin duda grupo con los otros apóstoles. Si fuera el de Aquino, o acompanaría $\mathrm{N}^{2} \mathrm{~S}^{2}{ }^{2}$ a los ángeles que le ceñian el cíngulo de castidad o iría éste como santo orante.

82 Como vemos, son mínimos los santos que en este siglo quedan sin identificar.

83 ¿Se tratará de alguna réplica de la serie de Rubens? El Lcd. ${ }^{\circ}$ Rodríguez de Tapia del que vimos arriba una pintura de condenado, tenía entre las obras de su biblioteca runas emblemas. (Prot. 6237, ff. 20 y ss.)

84 Sabemos de $\mathrm{J} .^{\circ}$ Fernández del Tablado que estaba vivo en el año 1686 , fecha en que, junto con su mujer, donaba a la ermita albercana de San Antonio de Padua el frontal 


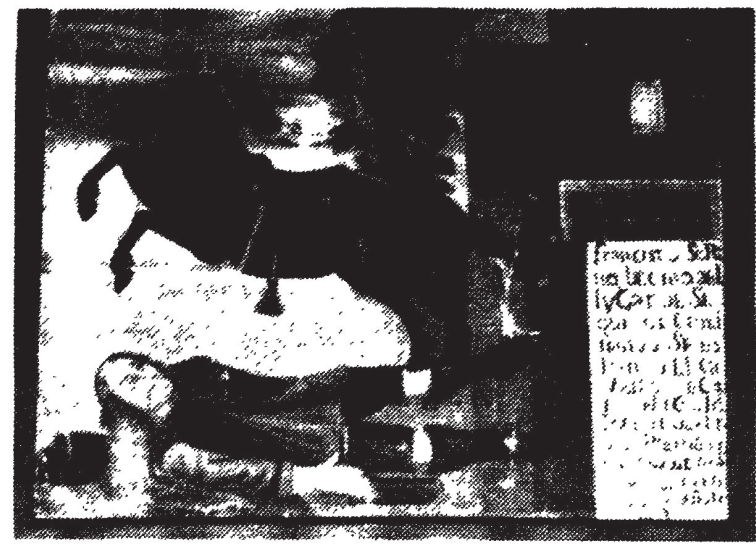

LÁM. XIII.-Las devociones privadas se hacían públicas en el caso de los exvotos pintados donde, además, se añadía el retrato del donante. Exvoto-retrato de Francisco Serrano, vecino de Sequeros, año 1673 (M." del Zarzoso, óleo sobre lienzo. Foto A. Cea, 1979).
- otro quadro con el retrato del fundador de la capellanía. 1782. Alberca, inv. Don Juan Santiago, Pbr. ${ }^{\circ}$ (Prot. 6120, f. 16v)

X. Personajes históricos $[(8), 1742-1771]$

- quatro pinturas de la casa de Austria de dos varas, sin marcos, a 30. 1742. Sequeros, inv. De Díez Zúñiga y Palomeque (Prot. 6243, f. 205)

- dos estampas, una del rey de España y otra del de Portugal. 1754. San Martín. Inventario (Prot. 6205, f.s.)

- dos quadros pequeños de medias cañas, del pontífice y el Rei. 1771. Cepeda, inv. Joachín Bueno, Bfd. ${ }^{\circ}$ (Prot. 6010, ff. 157-162) ${ }^{85}$

XI. OTROS PERSONAJES Y TEMAS

[(1), 1783]

- otro marco de cartta de ermandad. 1783. San Martín. Inventario (Prot, 6207, f. 8)

XII. LA DENOMINACIÓN DE PROCEDENCIA DESPLAZA EL TEMA DE L.A OBRA (72)

Obra de Francia [(8), 1742-1744]

- seis papeles de Franzia en bastidores, en $10 \mathrm{rs}$, otro papel de Franzia de San Antonio en 3 rs. 1742. Sequeros. Inventario (Prot. 6243, f. 201v)

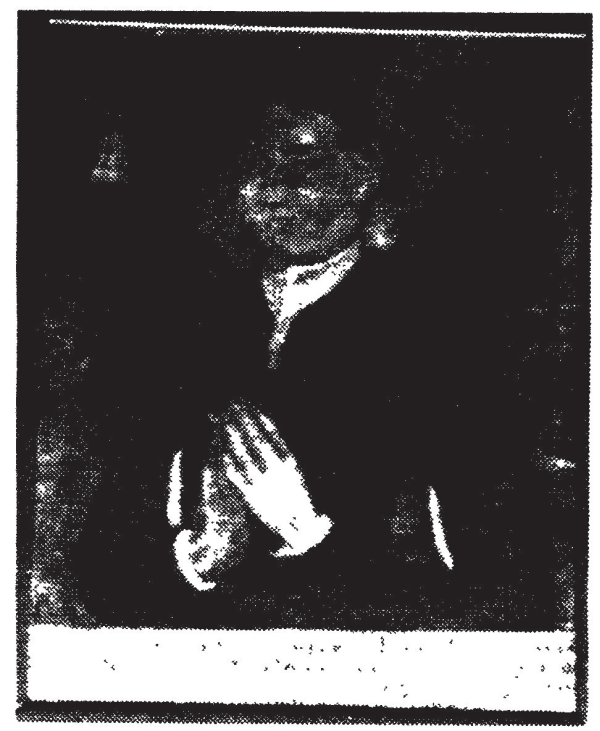

LÁM. XIV.-Exvoto-retrato de Juan Manuel Montejo, vecino de la Nava de Güebra, año 1787 (Óleo sobre lienzo, M. ${ }^{\circ}$ del Zarzoso. Foto A. Cea, 1979).

y las credencias de azulejos talaveranos que aún se conservan. Los temas laterales acogen las imágenes de San Antonio recibiendo al Niño Jesús, y los estigmas de San Francisco. El central, un Crucifijo, a cuyos pies corre la siguiente leyenda: DIOLE DE LIMOS/NA IVAN FERNAN/DEZ, DEL TABLA/DO. Y CATALINA,/MAILLO, SU MVI/ER. PVSOSE EN,/ EL AÑO DE/1686 AÑOS.

85 Parece que estuvieron bastante extendidas las series en pintura sobre Casas Reales, procedentes de talleres de segunda fila, en gran parte de Francia y también de Valladolid. Ello provocaba las quejas de pintores de fama que veían así menguada su obra. 
- un quadro de Franzia. 1744. Cepeda. Inventario (Prot. 6003, f. 88)

Obra de Sevilla [(1), 1745]

- quadro de San Antonio, viexo, echura de Sebilla. 1745. Sequeros, inv. Antonio Martín Fraile (Prot. 6243, f. 137v) ${ }^{87}$

Obra de Valencia [(6), 1783]

- seis quadros de Valencia, 4 reales cada uno. 1783. Miranda, inv. Juan Hernández Tapia (Prot. 6152, f. 241) ${ }^{88}$

Obra de Valladolid [(57), 1710-1760]

- un quadro de Balladolid. 1710. Cepeda. Inventario (Prot. 5999, f. 250)

- tres quadras de la fábrica de Balladolid, 8 rs. 1711. Candelario. Inventario (Prot. 1133, f. 6)

- Quadro de San Pedro, 3 rs, quadro del Salvador, 3 rs., quadro del Angel de la guarda, 3 rs. , quadro de la Virgen del Carmen, 3 rs., todos de la fábrica de Balladolid. 1712. Candelario. Inventario (Prot. 1133, f. 54)

- quadro de San Ildefonso, de la fábrica de Balladolid. 1711. Candelario. Inventario (Prot. 1133, f. 59)

- Dos quadras viejos de Valladolid, 6 rs. 1713. Candelario. Inventario (Prot. 1133, f. 23)

- cinco quadros de Valladolid. 1714. Sequeros. Inventario (Prot. 6238, f. 1)

- diez quadros de la calle de Santiago de Valladolid. 1715. Miranda, inv. Jerónimo Rodríguez de Ledesma. Escribano (Prot. 6144, ff. 51 y ss.)

86 En el contexto serrano podríamos suponer como de Francia, grabados de la Francia-advocación, pero son, en cambio, de tema francés "los seis papeles" (mitologías, asuntos novelescos o series históricas). Colección que contrasta con el también francés San Antonio, ahora de sujeto religioso y tasado más que los otros que no acertó a reconocer el escribano.

87 Pocas maneras podían gustar más a más público que las de la escuela sevillana. No obstante y a pesar de la comunicación entre nuestra comarca y la Andalucía por las constantes andaduras de los arrieros serranos, sólo podemos constatar como de Sevilla este San Antonio.

88 Primera vez que se documenta en la Sierra pintura de Valencia con estos seis ejemplos sin identificar, todos ellos en la misma colección mirandeña y estimados en un real más de media que los de Valladolid. En las cajoneras de Miranda del Castañar abundan los ternos de seda de Valencia y un tal "Mansilla, carpintero valenciano", se registra en el año 1772 con encargos de la cofradía de los Colorados en esa misma villa (APM. Libro Cofr. Colorados o Veintiquatro, de 1768, f. 28v). En inventario de Monforte de la Sierra y año 1797 se citan sunas cintas de Valencia nuevas. (Prot. 6183, f. 27). Sea lo que fuere, no tenemos noticia de una procedencia directa. No hay que olvidar, además, que lo que se denomina como de Valencia pudo tener su origen en el tan abundante comercio entre esa ciudad y Nápoles. 
- un quadro de Balladolid de la Soledad. 1718. Miranda, inv. María de Tapia (Prot. 6144, f. 43)

- dos quadros de pintura de Valladolid. 1737. Sequeros, inv. Ana Axensio (Prot. 6240, f. 9v)

- tres quadros de Valladolid, a 2 rs. 1743. Candelario, separata de inventario de Melchor Rico (Prot. 1137, f. 4)

- tres quadras de la calle de Santiago. 1744. Miranda, inv. Ángela de la Parra (Prot. 6164, f. 10)

- quadro biexo de la soledad, echura de valladolid. 1745. Sequeros, inv. Antonio Martín Fraile (Prot. 6243, f. 137v)

- Soledad de Pintura de Valladolid. 1754. Sequeros, inv. Juan Antonio Anaya (Prot. 6246, f. 164)

- dos quadros pequeños de Valladolid, 6 rs. 1758. Sequeros, inv. Mariana García Rubio (Prot. 6247, ff. 45v y ss.)

- dieciocho estampas de Balladolid. 1760. Sequeros, inv, Marcos Sánchez Montero (Prot. 6247, f. 90) ${ }^{89}$

Escaparates y obra de monjas [(9), 1737-1782]

- escaparate de paxa y en él un rosario de gueso. 1737. San Martín. Inventario (Prot. 6202, f. 130v)

- un relicario de monxas pequeño. 1741. Alberca, inv. Manuel González (Prot. 6108, f. 105v)

- dos quadrecitos de monjas guarnecidos de platilla, 16 rs. 1761. Sequeros, dote de Isavel Sánchez (Prot. 6247, f. 122)

- un escaparate pequeño con bidrio con diferentes enrreditos de barro, Regulado. 1771. Miranda. Inventario (Prot. 6149, f. 348)

- una caja pequeña con unas imagines, 10 rs. vellón. 1771. Miranda. Inventario (Prot. Ibid.)

- urna de seda con efixie pequeña de San Francisco con seis reliquias, 4 rs. 1777. Sequeros, Inv. Pedro Regalado García (Prot. 6252, f. 210)

- dos escaparates con varias figuras dentro. 1782. San Martín. Inventario (Prot. 6207, fs.)

89 El vasto número de obras de la fábrica de Valladolid supone una relación comercial de importancia con estas comarcas salmantinas, parece que siempre dentro del género religioso, o al menos en aquellas piezas - catorce- donde se reconoce la advocación: cinco de la Soledad, que prevalecen como prototipo, dos del Carmen, y uno de San Pedro, Santiago, el Salvador, Nombre de Jesús, Crucifijo, San Ildefonso y el Angel de la Guarda. Si descendemos a lo cotidiano, también otros enseres domésticos reciben nombre de esta ciudad: un jarro de Balladolid, en Cepeda y año 1703 (Prot. 5996, f. 113), o un candil de Valladolid. en inventario de Villanueva de 1773 (Prot. 6322, f. 28) 
XIII. TEMAS SIN IDENTIFICAR [(103), 1704-1783]

- Nuebe quadros con sus marcos de diferentes pinturas, mas quadro viexo. 1704. Sequeros, inv. Francisco Hernández Montero, Escribano (Prot. 6237, f. 23)

- doze Bitelas con sus marcos. 1709. Cepeda, inv. Francisco Díez Barrio, Essn. ${ }^{\circ}$ Público (Prot. 5999, f. 59v)

- veinte y tres laminitas de vitela con sus marcos negras. 1710. Cepeda, dote de Mariana Gallardo (5999, f. 170v)

- quadro dorado con sus puertas. 1711. Cepeda, inv. Lcd. ${ }^{\circ}$ Francisco Blanco (Prot. 5999, ff. 30-32)

- siete vitelas con sus maderas pequeñas. 1715. Miranda, inv. Jerónimo Rodríguez de Ledesma, Essn. ${ }^{\circ}$ (Prot. 6144, ff. 51 y ss.)

- Tres pedazos de Paramentos pintados de figuras, tasadas a veinte $r$. 1726. Sequeros, test. ${ }^{\circ}$ Ángela Rodríguez (Prot. 6239, f. 85) ${ }^{\%}$

- veinte y quatro quadros de Marco Dorado, 30 rs. vellón, más dos quadritos de Bronce y otro negro, $10 \mathrm{rs}$. vellón. 1743. Alberca, matrimonio de Antonio Pies de la Guebra (Prot. 6106, f. 184)

- quadrito con marco Tallado y dorado en 8 rs. 1743. Candelario, inv. Pedro Batanero (Prot. 1137, f. 29v)

- dos quadros grandes y otro pequeño. 1750. Miranda, inv. Don Antonio Rodríguez de Ledesma (Prot. 6175, ff. 91v y ss.)

- lámina pequeña con marco. 1760. Sequeros, inv. Marcos Sánchez Montero (Prot. 6247, f. 90v)

- dos quadros grandes. 1764. Sequeros, inv. Agustina González, vd." de Francisco Berrocal (Prot. 6248, f. 6)

- Tres figuras de ieso en real y medio. 1774. Sequeros, inv. Mathías Prieto (Prot. 6251, f. 140v)

- un quadro con bastidor y sin marco. 1781. Inventario (Prot. 6120, f. 30)

- diez quadritos diferentes pegados en tablillas. 1783. San Martín. Inventario (Prot. 6207, f. 8)

\section{SIGLO XIX}

I. EsCenas Del ANTIGUo testamento (no hay ejemplos)

90 Las figuras debían ser de carácter profano y los paramentos no otra cosa que -paños de pulir. 
II. Temas Del Nuevo Testamento (19)

VIDA DE CRISTO [(1), 1833]

Nacimiento [(1), 1833]

- un portal de Velén, 3 rs. 1833. Sotoserrano. Inventario (Prot. 6922 , sf.) ${ }^{91}$

VIDA DE MARÍ [(1), 1833]

Visitación [(1), 1833]

- quadro de la Visitación de Santa Isabel, 20 rs. 1833. Monforte. Inventario (Prot. 6920, f. 48)

Personntes aislados [(5), 1801-1841]

El Niño de la espina o la Pasión presentida, más la Virgen Niña hilando. [(1), 1833]

- lienzo que representa un niño mirándose el dedo, 20. otro [quadrol en lienzo que representa la niña bilando, 20. 1833. Monforte. Inventario (Prot. 6920 , f. 48) ${ }^{92}$

Ecce Homo [(3), 1833-1841]

- un eccebomo, 3 rs. 1833. Sotoserrano. Inventario (Prot. 6922, f. $48 v$ )

- cuadro de Ecce homo, 6 rs. quadro de otro eccebomo, 6. 1841. Candelario, inv. Bárbara Gómez (Prot. 1155, f. 10)

Nazareno [(1), 1801]

- Nazareno, 8 rs. 1801. Candelario. Inventario (Prot. 1143, f. 27)

Detalles sobre una persona [(3), 1801-1824]

Cara de Dios [(3), 1801-1824]

- otro [dosel] con la cara de Dios. 1801. Candelario. Inventario (Prot. Ibid.)

- dos efigies de Xt. ${ }^{\circ}$ 1824. Cepeda. Inventario (Prot. 6024, fs.)

91 Primera referencia documental en la Sierra de un Nacimiento doméstico.

92 Resulta bien sintomático que haya pasado inadvertida al tasador del siglo XIX la intención a lo divino de estos lienzos geminados, según su criterio dos piezas de género. Muy otra sería la función que cumplieran en vida de su viejo dueño. Dentro de la cultura del Barroco era difícil no ver en ellos otra cosa que la Pasión presentida del Niño Jesús espinario y la Virgen Niña. Es patente pues el discurso de la doble lectura. 


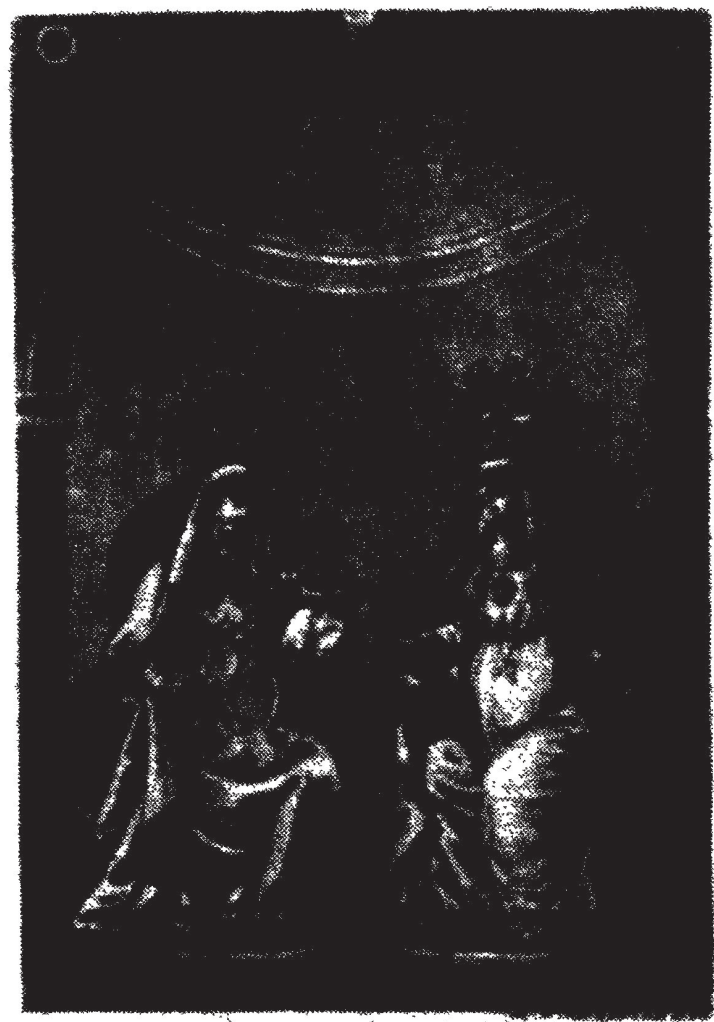

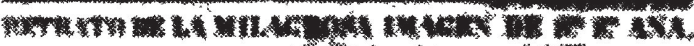

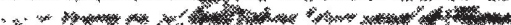

LÁM. XV.-Retrato de la imagen de Santa Ana como se venera en su parroquial de Triana. Grabado de José Manuel Martín, Sevilla, 1828. (Col. part. Madrid).

LA SAGRADA FAMmu [(2), 1833-1846]

La Parentela de Maria o el trinubtum de Santa Ana (simplificado) [(1), 1846]

- Las dos Matronas nuevo. 1846. Candelario, vienes de Félis y Eugenio Gradillas y su mujer Cecilia Rico Cabrero (Prot. 1155, f. $10 v)^{93}$ 1833]

San José, N." S." y el Niño [(1),

- San José, La Vingen y el niño, 8. 1833. Monforte. Inventario (Prot. 6920 , f. 48)

Niño Jesús [(3), 1801-1806]

- dos doseles con dos efigies de niño. 1801. Candelario. Inventario (Prot. 1143, f. 27)

- Niño Jesús de talla, $12 \mathrm{rs}$. 1806. Alberca, partija de María Pies (Prot. 6127, f. 36) 1846]

Crucifijos y Cruces [(4), 1814320 rs. 1814. Miranda. inv. de Don Miguel de Moreta (Prot. 6159, f. 137)

- un Cristo con dosel, 12 rs. 1814. Miranda, inv. Josefa Soriano Coca (Prot. 6159, f. 185)

- cruz de nácar, 11 [rs]. 1833. Monforte. Inventario (Prot. 6920, f. 48)

- un Cristo y una Vingen. 1846. Candelario, vienes de Félis y Eugenio Gradillas y su mujer Cecilia Rico Cabrera (Prot. 1155, f. 10v)

III. ADVOCACIONES MARIANAS (22)

DE CARÁCTER GENERAL [(10), 1801-1861]

Carmen [(3), 1803-1861]

- una $N^{a} S^{a}$ del Carmen con su media caña dorada de Valencia. 1803. Alberca. Inventario (Prot. 6127, f. 122v)

93 Pensamos que se trata de Santa Ana y María sedentes, entre cuyos regazos haría de puente el Niño, completando así la Parentela en su versión reducida. Con el nombre de slas dos matronas", clásico hasta desorientar, reconoció el escribano este asunto religioso y con él conocen hoy la famosa advocación de Santa Ana en Triana. 
- La Vingen del Carmen, 12 rs. 1846. Candelario, vienes de Félis y Eugenio Gradillas [...] (Prot. 1155, f. 10v)

- quadro del Carmen 3 rs. 1861. Candelario, dote de Cecilia Gradillas Bejarano (Prot. 7710, f. 3v)

Concepción [(2), 1803-1814]

- N. ${ }^{a}$ S. $^{a}$ de la Concepción, 10 rs. 1803. Alberca. Inventario (Prot. 6127, f. $122 \mathrm{v})$

- una concepzión con su peana, 16 rs. 1814. Miranda, inv. de Don Miguel de Moreta (Prot. 6159, f. 137)

Divina Pastora [(1), 1801]

- Divina Pastora, 8 rs. 1801. Candelario. Inventario (Prot. 1143, f. 27$)^{94}$

Dolores [(1), 1801]

- Dolores, 8 rs. 1801. Candelario. Inventario (Prot. Ibid.) ${ }^{95}$

Pilar [(3), 1824-1846]

- un cuadrito del Pilar. 1824. Candelario. Inventario (Prot. 6024, fs.)

- imagen del Pilar, 8rs. 1841. Candelario, inv. Bárbara Gómez (Prot. 1155, f. 10)

- La Virgen del Pilar en 4 rs. 1846. Candelario, vienes de Félis y Eugenio Gradillas [...] (Prot. 1155, f. 10v)

\section{Particulares o TOPOgráficas}

[(5), 1801-1853]

Cuesta [(1), 1842]

- una Virgen de $N^{a} S^{a}$ de la

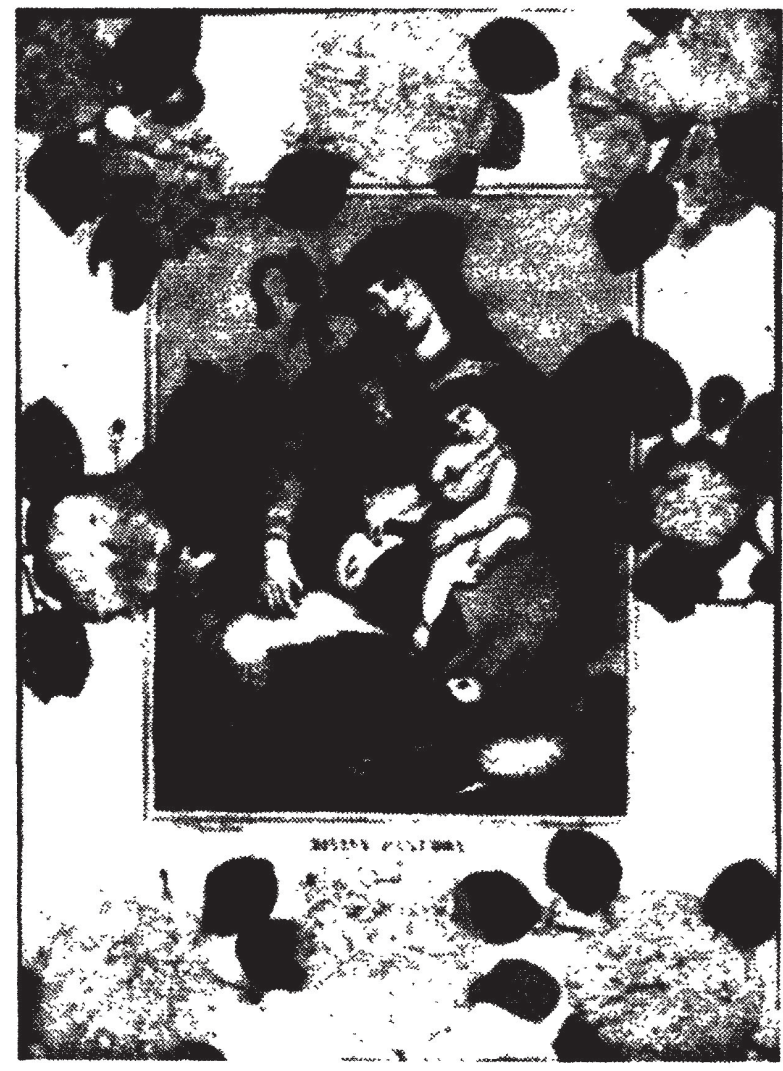

LÁM. XVI.-Grabado iluminado de la Divina Pastora. La guarnición de rosas de tela y cera es "obra de monjas". Fc. ${ }^{\circ}$ Mitjana, Málaga, s. XIX. (Col. part. Madrid). Cuesta con manto de seda blanca, vordado de oro a realze, rostrillo y buelos de encaje fino, mil doscientos rs. 1842. Miranda, dote de Don Mariano Díez Nieto de la Peña (Prot. 6917, f. 163v) ${ }^{96}$

94 Primera y única vez que documentamos esta dieciochesca devoción capuchina.

95 A este solo ejemplo se ve reducida en el siglo XIX la iconografía de la Virgen Dolorosa. No queda rastro, o al menos deja de mencionarse la, en los otros dos siglos, mal llamada Soledad de Valladolid.

* Imagen vestidera, seguramente de las de modalidad catalana si la suponemos coetánea al inventario, lo que parece evidente considerando la tan costosa suma en que 
Gracia [(1), 1801]

- estampa de N. ${ }^{a} .^{a}$ de Grazia. 1801. Candelario. Inventario (Prot. 1143, f. 27)

Nieva [(1), 1837]

- estampa de seda con una media caña y es de la imagen de Nieva, 6 rs. 1837. San Martín. Inventario (Prot. 6940, f. 24) ${ }^{97}$

Francia [(19, 1831]

- quadro sobre cristal de la Vingen de la Peña. 1831. Casas del Conde. Inventario (Prot. 6901, ff. 89 y ss.)

Socorro [(1), 1853]

- Efigie del Socorro. 1853. Sotoserrano, dote de M. Marcos González (Prot. 6945, sf.) ${ }^{98}$

De $\mathbf{N}_{.^{2}}{ }^{2} .^{2} \sin$ especificar [(7), 1814-1862]

- una $N^{a}{ }^{a}{ }^{a}$ en un quadro de ojadelata, 6 r. 1814. Miranda, inv. Josefa Soriano Coca (Prot. 6159, f. 185)

- una $N^{a} S^{a}, 10$ rs. 1834. Miranda, inv. Ma Pérez (Prot. 6915 sf.)

- tres estampas. 1837. San Martín. Inventario (Pro. 6940, f. 24)

- un Cristo y una Virgen. 1846. Candelario, vienes de Félis y Eugenio Gradillas [...] (Prot. 1155, f. 10v)

- cuadro de N. ${ }^{a}$ S. $^{a}, 6$ rs. 1862. Candelario, test. ${ }^{\circ}$ Petra Bejarano Bayo (Prot. 7710, f. 7)

fue valorada, inalcanzable para una obra vieja. Se detallan como en pocas ocasiones los pormenores de la indumentaria, materiales y técnicas en que iba bordada y otras guarniciones. Es la primera vez en toda la documentación manejada que una devoción pública se desdobla en réplica privatizada, de manera tan rica y en una casa noble de la misma localidad donde recibe culto oficial. Curiosamente la Cofradía de la Cuesta, conocida también como "del Hospital" o "de las Vacas" y cuyas ordenanzas había aprobado el Rey Carlos III, prohibe su ingreso en ella a quien no pertenezca al estrato llano o de homesbuenos.

97 Extraña que solo se haya registrado en las colecciones serranas un ejemplo de esta devoción tan extendida, siendo abogada contra rayos y centellas y favorecedora de los buenos partos. No así en joyería, donde entre los años 1765 y 1800 quedan inventariadas nueve medallas de Nieva que se reparten entre los lugares de Villanueva, Cepeda, La Alberca, Sotoserrano y Candelario.

* La advocación del Socorro tiene santuario en San Martín del Castañar y es una de las ocho tradicionalmente tenidas por Patronas de la Sierra de Francia. Es de hechura vestidera y no sabemos que se hiciera de ella estampa alguna. Si se alude a la iconografía general, la del Socorro entra dentro del esquema de María como protectora. El Niño en su brazo izquierdo y empuñando con el derecho un bastón con el que amenaza al demonio que, a sus pies, se afana por robar un alma niña. 
IV. SANTORAL [(25), 1801-1862]

SANTAS [(3), 1803-1846]

Bárbara [(1), 1803]

f. $122 \mathrm{v})$

Cecilia [(1), 1846]

- un cuadro de Santa Cecilia, 14 rs. 1846. Candelario, vienes de Félis y Eugenio Gradillas [...] (Prot. 1155, f. 10v)

Teresa [(1), 1833]

- Santa Teresa de yeso, $24 \mathrm{mrs}$. 1833. Sotoserrano. Inventario (Prot. 6922, f. $48 \mathrm{v})$

SANTOS [(11), 1801-1862]

Los Apóstoles [(1), 1833]

- quadrito de nácar que representa el apostolado, 12. 1833. Monforte. Inventario (Prot. 6920, f. 48)

Antonio [(2), 1801]

- dos lquadrosl de San Antonio, 8 rs. 1801. Candelario. Inventario (Prot. 1143 , f. 27)

Fernando [(1), 1831]

- quadro sobre cristal de San Fernando. 1831. Casas del Conde. Inventario (Prot. 6901, ff. 89 y ss.)

Jerónimo [(1), 1803]

- un San Gerónimo con marco dorado, 8 rs. 1803. Alberca. Inventario (Prot. 6127, f. 122v)

Juan Bautista [(1), 1833]

- quadro de San Juan Bautista. 1833. Sotoserrano. Inventario (Prot. 6922, f. $48 \mathrm{v})$

Miguel Arcángel [(1), 1823] 6024, sf.)

- un San Miguel en una media caña. 1823. Cepeda. Inventario (Prot.

Pedro [(1), 1862]

- cuadro de San Pedro, 8 rs. 1862. Candelario, test. ${ }^{\circ}$ Petra Bejarano Bayo (Prot. 7710, f. 7)

Rafael Arcángel [(1), 1833] f. $48 \mathrm{v})$

- quadro de San Rafael. 1833. Sotoserrano. Inventario (Prot. 6922, 


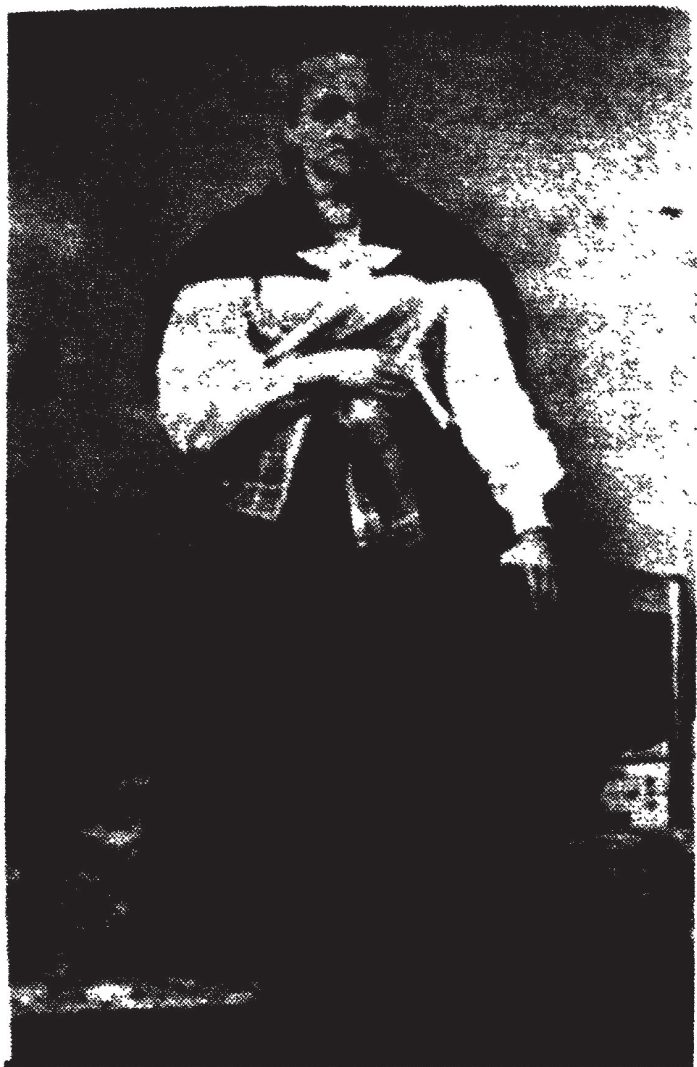

LÁM. XVII.-A partir de la $2 .^{a}$ mitad del siglo xIX, la fotografía comenzó a suplantar al retrato y el verbo retratar era empleado en ambos casos indistintamente. (Serrana de Mogarraz, c. 1890, col. Calvo Cascón).
Tomás apóstol [(1), 1833]

- un quadro de Santo Tomás, 20. 1833. Monforte. Inventario (Prot. 6920, f. 48)

Tomás de Aquino [(1), 1833]

- quadro de Santo Tomás de Aquino, 30. 1833. Monforte. Inventario (Prot. Ibid)

Sin identificar [(10), 1803]

- seis santos de varro pequeños en 6 rs. cuatro santos de yeso, 4 rs. 1803. Alberca. Inventario (Prot. 6127, f. 137)

V. TEMAS DEL ALMA: LAS POSTRIMERIAS Y LOS JUICIOS (no hay ejemplos)

VI. El País [(2), 1833]

- dos quadros de países sin marcos, 16. 1833. Monforte. Inventario (Prot. 6920, f. 48)

El Pais de caza [(2), 1833]

- dos quadros de lienzo largos $f i$ -

gurando países de caza, 26. 1833. Monforte (Ibid)

VII. El BODEGÓN [(1), 1833] $(\text { Ibid. })^{99}$

- otro [quadrol que representa cosas de comer, 8 rs. 1833. Monforte VIII. TEMAS mItOlóGICOS, ALEGORÍAS Y emBlemas (no hay ejemplos)

IX. El RETRATO [(2), 1833-1863]

- El retrato de la difunta y el enunciado, en fotografía y marco dorado. 1863. Candelario, vienes de Don Tomás Pantaleón Rico (Prot. 7749, f. 10) ${ }^{100}$

9) Este inventario de clérigo monforteño, dentro de su humildad es el ejemplo más expresivo de colección no supeditada a lo religioso, sino abierta y compensada por otros géneros: paisaje y paisaje de caza, bodegón, retrato y temas históricos.

100 Este primer y último ejemplo de retrato-fotografía con leyenda al pie, inicia una fórmula nueva y avanzada en época tan temprana, dentro de un contexto de familia 


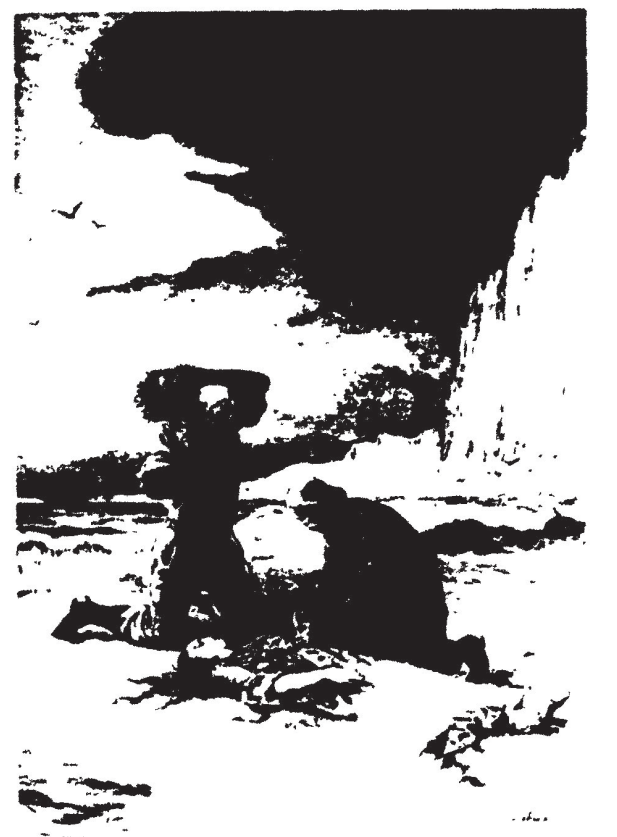

- otro de una figura de medio cuerpo sin marco, 8. 1833. Monforte (Ibid.)

X. PERSONAJes históRICOS [(4), 1861]

- cuatro cuadros de Don Juan de Austria, 120 rs. Espejo dorado y un cuadro, $60 \mathrm{rs}$. 1861. Candelario, test. ${ }^{\circ}$ Ana Campo (Prot. 7710 , f. 2) ${ }^{101}$

XI. OTROS PERSONAJES Y temas [(8), 1833]

- ocho láminas en papel que representan varones Ilustres, $80 \mathrm{rs}$. 1833. Monforte (Ibid.)

XII. LA DENOMINACIÓN DE PROCEDENCIA DESPLAZA EL TEMA DE LA OBRA [(15), 1801-1865]

Obra de Francia o "historias" [(7), 1862] - tres cuadros de Pablo y Virginia, 12 rs. Cuatro de otras historias. 1862. Candelario, test. $^{\circ}$ Ángel Hoyos (Prot. 7710, f. 3) ${ }^{102}$

Obra de Sevilla (no hay ejemplos)

Obra de Valencia [(6), 1801-1803]

- Cuatro láminas de Valencia con marco dorado, $28 \mathrm{rs}$. 1801. Alberca. Inventario (Prot. 6126, f. 93)

- estampa con la custodia con marco dorado, de Valencia, 4. Una $N^{a}{ }^{a}{ }^{a}$ del Car-

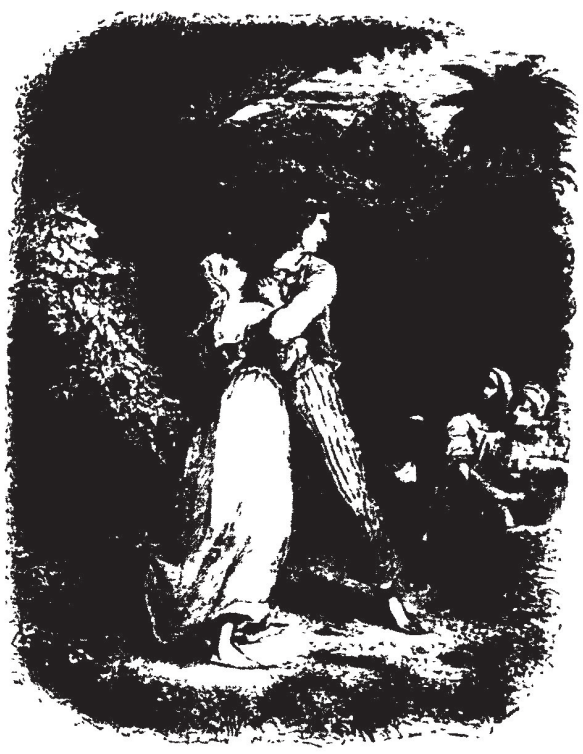

LÁms. XVIII y XIX.-Historia de Pablo y Vinginia. Ilustraciones para la edición de París de 1875, y la londinense del año 1879. (Madrid, Biblioteca J. Portús).

acomodada. Cabe, además, la posibilidad de que se tratara no de un retrato en vida de la difunta, sino :de difunta".

101 Los conceptos de "antiguo" y "viejo", durante tiempo sinónimos de desvalorizado y arrinconable, parecen aquí revisados. Estas cuatro obras debieron justipreciarse de manera tan alta por su valor intrínseco, no se salvó la tasación gracias a unos marcos ricos que para nada se mencionan.

102 La historia de Pablo y Virginia de Bernardino de Saint Pierre, nacido en Havre en 1737, tuvo pronta divulgación, en parte, gracias a las llamativas ilustraciones de sus más famosas ediciones, como la parisina de 1875 con grabados de Laguillermie o la londinense de 1879 , de las que incluimos ejemplos. 
men con su media [caña] dorada de Valencia, $10 \mathrm{rs.} \mathrm{Una} \mathrm{lámina} \mathrm{de} \mathrm{Valencia,}$ 4 rs. 1803. Alberca. Inventario (Prot. 6127, f. 122v) ${ }^{103}$

Obra de Valladolid (no hay ejemplos)

Escaparates y obra de monjas [(2), 1834-1865]

- una hurnia con dos ymágenes, 30 rs. 1834. Miranda, inv. Don Marcelino González (Prot. 6915, sf.)

- Escaparate de flones de 10 rs. 1865. Linares. Inventario (Prot. 8029, sf.)

XIII. TEMAS SIN IDENTIFICAR [(18), 1834-1865]

- una lámina en 4 rs. 1834. Miranda, inv. María Rodríguez (Prot. 6915, sf.)

- once cuadros viejos, 11 rs., más dos espejos grandes, 70. 1846. Candelario, vienes de Félis Gradillas [...] (Prot. 1155, f. 10v) ${ }^{104}$

- seis cuadros en la sala del criado, 6 rs. 1865. Candelario, test. ${ }^{\circ}$ de Doña Antonia Rico López (Prot. 7751, f. 27) ${ }^{105}$

\section{RESUMEN VALORATIVO}

Aparecen solo representados 13 pueblos (de los 37 que comprendía la Sierra de Francia), además de Candelario, en 190 inventarios entre los siglos XVII y XIX. El primer documento se registra en San Martín del Castañar en el año 1631, el último en 1865, en Candelario y Linares respectivamente. En el siglo XVII se tasaron 304 obras, 560 en el siglo xviI y por último 117 en el siglo Xxx, lo que suma un total de 981 obras entre los pueblos que se citan.

103 Se incrementa en este siglo la obra de Valencia con guarnición de marcos dorados, detalle que parece caracterizarla y desaparece, en cambio, todo rastro de la de Valladolid, que tan arraigada había estado en estas comarcas años atrás. Se registra también en dos inventarios loza valenciana: catorze platos de Valencia, 14 rs., nueve tazas de Valencia, 3, (1809. San Martín, inv. Presbítero Alexo Sanz. Prot. 6213, f. 48v); cinco platos y cinco medias fuentes de Balencia. (1819. San Martín. Inv. Rosa Benito. Prot. 6215 , sf.)

104 En este documento podemos aún comprobar el canon estimativo, en desventaja para la pintura, por vieja que fuera, cuando se compara con otras piezas mobiliarias.

105 Aparece la sala del criado como sola referencia de pinturas en casa de Doña Antonia Rico. El corto precio de la tasación hace suponer que fueran ya viejas, y si eran las únicas, como parece, es que la difunta se habría desprendido en vida de lo superfluo, mejorando de hecho, al criado. 


\begin{tabular}{|l|c|c|c|r|}
\hline \multicolumn{1}{|c|}{ LOCAIIDAD } & XVII & XVII & XIX & SUMA \\
\hline LA ALBERCA (1743-1833) & & $3.68 \%$ & $1.05 \%$ & $4.73 \%$ \\
\hline ARROYOMUERTO (1722) & & $0.52 \%$ & & $0.52 \%$ \\
\hline CASAS DEL CONDE (1831) & & & $0.52 \%$ & $0.52 \%$ \\
\hline CEPEDA (1648-1824) & $12.63 \%$ & $7.89 \%$ & $1.05 \%$ & $* 21.57 \%$ \\
\hline GARCIBUEY (1774-1775) & & $1.57 \%$ & & $1.57 \%$ \\
\hline LINARES (1865) & & & $0.52 \%$ & $0.52 \%$ \\
\hline MIRANDA (1710-1842) & & $7.89 \%$ & $3.15 \%$ & $* 11.05 \%$ \\
\hline MONFORTE (1755-1833) & & $1.05 \%$ & $1.57 \%$ & $2.63 \%$ \\
\hline SAN ESTEBAN (1651) & $0.52 \%$ & & & $0.52 \%$ \\
\hline SAN MARTIN (1631-1837) & $7.36 \%$ & $8.42 \%$ & $0.52 \%$ & $* 16.31 \%$ \\
\hline SEQUEROS (1652-1777) & $7.36 \%$ & $22.10 \%$ & & $* 29.47 \%$ \\
\hline SOTOSERRANO (1777-1853) & & $0.52 \%$ & $1.05 \%$ & $1.57 \%$ \\
\hline VILLANUEVA (1772) & & $0.52 \%$ & & $0.52 \%$ \\
\hline CANDELARIO (1711-1865) & & $4.21 \%$ & $5.26 \%$ & $9.47 \%$ \\
\hline
\end{tabular}

TABla I.-Geografia de la frecuencia documental de inventarios, en la Sierra de Francia y Candelario. Siglos XVII-XIX.

Como se aprecia en la TABLA I, cuatro de estas localidades sólo registran un inventario, en dos se oscila entre el $5,26 \%$ y el $13,15 \%$ del total de los protocolos recogidos. Las villas de Cepeda y San Martín comprenden entre ambas el $37,36 \%$ ( $16,31 \%$ y $21,57 \%$ respectivamente) y solo una (Sequeros) alcanza las 56 entradas, representando el $29,47 \%$. Podemos resumir que el 66,83 de los inventarios se producen en estas tres últimas localidades.

Las colecciones serranas tienen en el siglo XV un ilustre precedente en la de Doña María de Sandoval, segunda condesa de Miranda del Castañar. En documento del año 1493 (Memoria de lo q pagué por menudo por mandado de la señra q(ondes]a de myranda (...) el administrador anota puntualmente los gastos de su ama. Dicha condesa que pasaba a la sazón temporada en sus palacios de Iscar, realiza por medio de criados y demandaderas, varios encargos en Valladolid y en la feria de Medina, entre los que se citan algunas imágenes de valor y telas para su adomo:

Mas en 13 de enero q di a gandía $\mathrm{p}^{2}$ ciertas cosas $q$ le manda comprar $=1.186 \mathrm{mrs}$ [...] Mas en 5 de mayo $q$ di a gandía q le enbió (la condesa) a Vlalladolild su S. ${ }^{a}$ no sé a qué $=1.013 \mathrm{mrs}$. Mas en este día q di a la de $\mathrm{J}^{\circ}{ }^{\circ}$ de tapia por çiertas cosas q de ally compró $=2.335 \mathrm{mrs}$.

Mas por çiertas cosas de oro q mandó comprar con una débano de san gregorio (imagen) $=6.716 \mathrm{mrs}$. 
Mas q dí por una ymagen $=2.062 \mathrm{mrs}$

Mas por adornar la muy fina ymagen a un entallador $=1.000 \mathrm{mrs}$. Mas de çierto paño q se sacó de m[anols de franc..$^{\circ}$ ortega q[ualndo estava en Vlalladoli]d $=1.266 \mathrm{mrs}$. Mas a di[eg]. ${ }^{\circ}$ de la quus q mandó dar por una ymagen o no sé por $\mathrm{q}$, al qual dí çédula, q yba p. $^{2}$ la feria de M[edin]. ${ }^{2}=3.000 \mathrm{mrs}$.

Adquiere pues la condesa en este lote de piezas devocionales tres nuevas hechuras de talla. La primera nos da noticia del material (ébano) y la advocación (S. Gregorio). La segunda, que se describe como "muy fina", se mandó adornar a un entallador. ¿Sería la encarnación y estofado lo que se le encargaba al tal entallador, o que se hiciera cargo, si era el propio autor, también del alhajamiento y vestidos de la imagen? Dos procedían de Valladolid y la tercera, de la que nada se detalla, fue mercada en la feria de Medina de Campo ${ }^{106}$.

Dentro de los casi doscientos inventarios, las mejores colecciones y de mayor interés iconográfico, van repartidas entre las casas de clérigos y escribanos, muchos de ellos, además, de procedencia noble ${ }^{107}$.

106 (AGS. Diversos de Castilla, Leg. 41, núm. 43, ff. 43-43v). Durante los siglos Xv y Xvi la fama de las colecciones de joyas y otras alhajas de las condesas de Miranda fue proverbial. En el caso de Dña. María de Sandoval se une al interés de las piezas el de las vejaciones a las que se vio sometida por su hijo Don Pedro Manrique, Duque de Nájera y Conde de Treviño, como para ser comentadas en una historia de vida. Por carta de los R.R.C.C. a dicho Pedro Manrique sabemos que fue por él prendida y durante cinco meses encerrada en la fortaleza de Salvatierra de Tormes: a....]e la tomaste muchas joyas de oro e plata e otras cosas [...], que la soltedes de dha prisión [...]e le dedes e restituyades las dchas joyas, e oro e plata e moneda amonedada" (AGS. Registro General del Sello, IV, 1480 , f. 141). En el año 1491 la duquesa de Plasencia había empeñado un joyel a un tal Fernando Monroy en $150.000 \mathrm{mrs}$. Este, a su vez, lo empeñó a la condesa de Miranda quien lo adquirió por $60.000 \mathrm{mrs}$. y fue una de las joyas que le arrebató su hijo cuando la tomó prisionera, empeñándola éste de nuevo a un tal Polo mercader. Los RRCC mandan que le sea restituida (AGS-RGS. X, 1491, f. 197). Doña María de Cárdenas, la cuarta condesa de Miranda, poseía la más abundante colección de piezas de azabache que se conoce (ver en Filgueira VAlVERDE, Azabaches compostelanos, Vigo, 1965).

107 Distribución de la piezas en las colecciones de cargos públicos y oficios:

\section{Licenciado clérigos (12)}

SIGLO XVII

- Manuel Pérez de Toribio. Cepeda, 1690 (26 obras)

- Francisco Ximénez, párroco. San Martín, 1694 (3 obras)

- Gonzalo López de Sanz. San Martín, 1699 (24 obras)

SIGLO XVIII

- Fc. ${ }^{\circ}$ Hernández de Mateo. Sequeros, 1705 (1 obra)

- Juan Rodríguez de Tapia. Sequeros, 1705 (4 obras)

- Francisco Blanco. Cepeda. 1711 (4 obras)

- Miguel Pozo. Sequeros, 1733 (1 obra) 


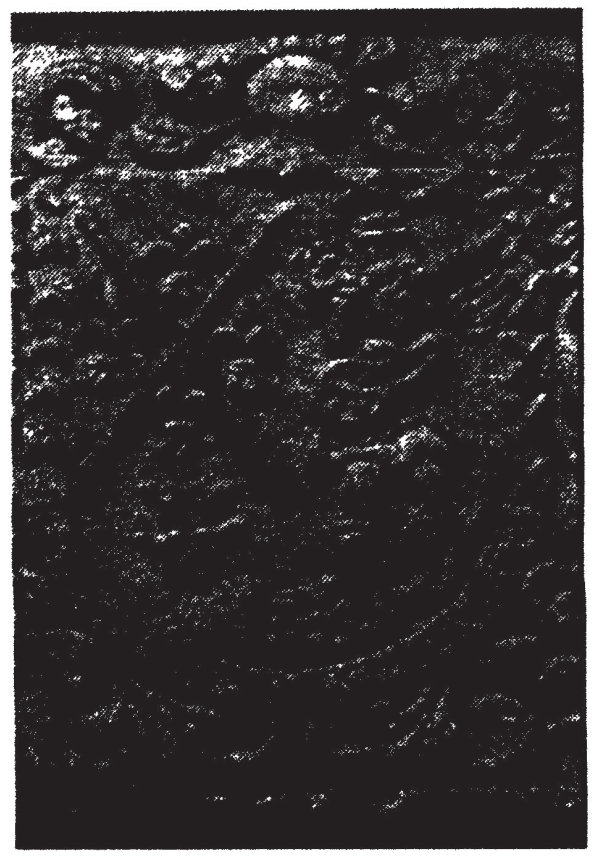

A través del estudio de estas colecciones de clérigos y escribanos podemos establecer un perfil-tipo por razón de oficio. Salvo el inventario del clérigo de Monforte en la tardía fecha de 1833, que calificamos como excepcional ${ }^{108}$, los once restantes adolecen de características comunes de fondo y forma. Las colecciones de los clérigos son, por lo general, más cortas que las de los escribanos. No parece entreverse en ellas una preocupación

LÁM. XX.-Escudo de armas de la casa conocida como "del escribano", Don Jerónimo Rodríguez de Ledesma, San Miguel y Escalante, cuya colección devocional (31 obras) aparece reflejada en estos documentos. (Miranda del Castañar, foto A. Cea, 1979).

- Díez Zúñiga y Palomeque. Sequeros, 1742 (24 obras)

- Antonio Rodríguez de Ledesma. Miranda, 1765 (6 obras)

- Joachín Bueno. Cepeda, 1771 (5 obras)

- Juan Santiago. Alberca, 1782 (15 obras)

SIGLO XIX

- El presbítero de Monforte. Monforte, 1833 (22 obras)

\section{Escribanos (7)}

SIGLO XVII

- Viuda de Francisco del Mercado. San Martín, 1671 (10 obras)

- Domingo García Callejo. San Martín, 1671 (1 obra)

SIGLO XVIII

- Fc. ${ }^{\circ}$ Hernández Montero. Sequeros, 1704 (15 obras)

- Fc. ${ }^{\circ}$ Díez Barrio. Cepeda, 1709 (15 obras)

- Jerónimo Rodríguez de Ledesma. Miranda, 1715 (31 obras)

- Hijos de Fc. ${ }^{\circ}$ Díez. Sequeros 1742 (10 obras)

- Viuda de Fc. ${ }^{\circ}$ Berrocal. Sequeros, 1764 (10 obras)

SIGLO XVII

Maestro. Juan Fernández. Cepeda, 1642 (7 obras)

Zapatero. Francisco Xil. Cepeda, 1651 (1 obra)

SIGLO XVIII

Boticario, San Martín, 1700 ( 8 obras)

Herrador. Juan González. Cepeda, 1704 (6 obras)

Cerero. Conocido como :Bastida. Arroyomuerto, 1722 (1 obra)

Batanero. Pedro Batanero. Candelario, 1743 (9 obras)

Platero. Joseph Román. Alberca, 1754 (2 cornucopias doradas)

Alcalde. Matías Hernández. Sotoserrano, 1773 (1 obra)

108 Esta colección monforteña compuesta por 22 obras es, probablemente, el ejemplo más armónico de orientación estética no sesgada por su oficio y con el equilibrio de otros 
por la calidad ni el criterio de unidad en la guarnición con marcos espléndidos formando series. Abundan tanto los lienzos como las estampas y suelen enmarcarse con cañas o medias cañas. Sobre el gusto prima la devoción no personalista sino conducida por las directrices generales de la Iglesia. Coincide en dos inventarios el tema de los Apóstoles y predominan los Crucifijos y Cruces, las hechuras del Niño Jesús, las representaciones - preferentemente de bulto y con una cierta calidad- de $N^{2}{ }^{2}{ }^{2}{ }^{2}$, sobre todo de la Concepción. Algún pasaje de la vida de Cristo y advocaciones de la Virgen con muy escasos ejemplos locales.

Respecto al santoral son Teresa, Tomás y los dos Antonios (Abad y de Padua) los más acogidos en las casas de los clérigos. Puede darse rara vez algún relicario a finales del siglo XVII, indicativo aún de las consignas tridentinas.

Las colecciones de los escribanos son de repertorio más abierto y numeroso, prevaleciendo el concepto estético sobre el de devoción. Predominio de la pintura sobre lienzo y cobre o lámina metálica con preferencia por temas pormenorizados de la vida de Cristo, advocaciones locales, santoral amplio e inclusión mayor de otros géneros no exclusivamente religiosos. Abundan las obras de gran tamaño guarnecidas con ricas tarjetas doradas.

El resto de las colecciones pertenecientes a otros cargos públicos y oficios (alcalde, boticario, platero, zapatero...) son cortas, aunque relacionan en proporción más justa el binomio gusto-devoción. Tratamiento aparte merece la colección del candelario Pedro Batanero que, aunque con solo diez obras, todas ellas religiosas, puede calificarse salvo dos piezas muy reiteradas (Soledad y Antonio de Padua) de obsesiva (aparecen dos S. Migueles) selecta (una Trinidad) y especializada en advocaciones de acarreo restringido (santos Javier, Félix Cantalicio, Claudio y Francisco Caraciolo). En cierto sentido casi todos estos últimos temas podrían formar parte de lo que ha dado en llamarse "santoral extravaganten.

En la valoración de los fondos que nos ocupan, los veedores, tasadores y escribanos pueden reflejar en los documentos o, en cambio omitir, todos y cada uno de los elementos que ayudan a justipreciar con objetividad y detalle la obra y que enunciamos a continuación.

- Se describe la pieza solo cuantitativamente.

- Se determinan el soporte, medidas, materiales y guarnición sin especificar el sujeto o tema.

- Se desvela además la advocación, pero no se dibuja su "paisaje. concreto: personas que componen la obra, actitudes, atributos, jerarquía, etc.

géneros aparte del religioso: paisajes y escenas de caza, bodegón, retrato y asuntos históricos. 
- Se ofrece una denominación iconográfica comodín, ambigua e impropia (Dolores por Piedad, o Soledad por Angustias)que a veces por otros datos aportados, es salvable o logra verificarse.

- No sólo se determina el pasaje iconográfico sino que se pormenorizan detalles de composición, gestos, figuras, colores asociados a símbolos, etc.

- Se vierte algún juicio de valor sobre la calidad y grado de empatía con la obra, añadiendo al tema apelativos cariñosos o familiares ${ }^{109}$.

- Existe capacidad de valoración propia o se apela al reconocido aprecio de los que entienden, en cuyo caso se califica como ade mérito.

- Además de todo esto, se conoce la procedencia como producto y como bien heredado, su escuela y autoría y se tasa.

- Se indica de quién se recibe, a quién se cede, el uso a que va destinada y, a veces, su ubicación.

- Se registra su situación de pervivencia, apreciándose como obra nueva, mediada o en regular estado y vieja o traída. Puede valorarse, además, teniendo como medida los gustos de cada momento o época: pieza antigua, a la moda, según la calidad de los materiales, etc.

No existe correspondencia, como parecería lógico, entre las devociones domésticas ("los santos de pared y mesa"), las que se utilizan en indumentaria (joyas-relicario, cruces, medallas y patenas) y las que reciben culto público en santuarios, iglesias, ermitas y humilladeros. Van cada una por su lado y en su sitio: los santos en las iglesias y ermitas, los santos en las casas y los santos en la indumentaria. En este abastecimiento debieron influir no poco las distintas vías y cultos.

Advocación tan omnipresente en la Sierra de Francia como es la de San Sebastián - uno de los tres denominados asantos de la peste" con San Fabián y San Roque-, de adscripción original en ermitas y refugiado luego en las iglesias, solo se registra una única vez como devoción doméstica. Por contra, santos muy socorridos en las casas como San Francisco y Santa Teresa se cuentan en las iglesias serranas con los dedos de la mano y sobran ${ }^{110}$.

109 Aunque con imágenes de culto público valgan los siguientes ejemplos: La Sagrada Familia (Santa Ana, San José, María y el Niño) que bajo hornacina renacentista se acoge en la capilla mayor y parroquial de Cepeda, recibe en los documentos como segundo nombre el de Nuestra Señora del Patrocinio o Jesús de Belén. Además, tiene un tercer cariñoso apelativo, el Montonito de la Buena Gente. En Miranda del Castañar Nuestra Señora de la Cuesta es llamada en familia La Oliva por el árbol en que fue aparecida. La románica $N^{a}{ }^{a} .^{a}$ con Niño descubierta por el pastor Froilán bajo una peña en la dehesa albercana, se conoce con el topónimo de Majadas Viejas, pero por lo devota que es de agua el día de su fiesta, la llaman en la Alberca, de puertas adentro, La Lloverina.

110 En el caso de la devoción a San Francisco están por medio el monasterio de Santa María de Gracia en San Martín del Castañar y el de Nuestra Señora de Portaceli en el Zarzoso, ambos con posibilidad de incidencia desde el siglo $\mathrm{xv}$, y el de Zarzoso aún en pie. 
¿Cómo explicar este desajuste? Salvo algunos patronazgos de carácter universal y sustentados en cofradías (las del Santísimo, el Rosario, Veracruz, Ánimas, etc.) que se incorporaban al culto público por exigencias del poder de las distintas Órdenes Religiosas, influyentes en su momento, o por los intereses de la Iglesia que recompensaba con bulas y privilegios, pensamos que en las tres categorías arriba expresadas, es el pueblo quien elige las devociones, aunque de distinta manera.

Parece pues que no quisieran verse repetidos los santos en su triple tipo de altar, o que hubiera tres cauces distintos de devoción, dos de los cuales eran de carácter particular.

La petición de milagros a los santos sanadores, las apariciones y los rituales parecen solo propios del culto calificado como público. Las devociones domésticas cubren intereses privados y admiten santos que denominaríamos de "adicción razonada". Su capacidad de expansión y penetración suele ir directamente relacionada con el sentido comercial que cada Orden Religiosa tiene de su propio panteón. Los santos y reliquias que se adscriben a la indumentaria como parte de las joyas, participan, a mitades, de las otras dos categorías. La falta de coordinación entre las tres como resultado deriva, en gran medida, de los focos de producción y de las descompensadas fuerzas en su distribución. A veces, una devoción entra en casa solo por ser homónima de su dueño. Es el caso de Doña Juana de la Huebra que, por si fuera poco uno, acoge a dos santos Juanes: El Bautista y el de Sahagún. Los santos raros y las vírgenes locales se adquieren por devoción, los universales y la advocaciones generales, además, a capricho.

Se contabiliza documentalmente casi en un siglo el retraso de las devociones de pared y de mesa (cuadros e imágenes de bulto) sobre las de colgar al cuerpo en vueltas y brazaleras como imagen-joya (cruces, medallas y relicarios). No parece haber otra razón antropológica o social que la valedera en arte. Las colecciones tienen en el Renacimiento un comienzo elitista y un sentido que va exclusivamente asociado a la figura del noble y del clérigo. No se admite en los siglos XV y XVI la pieza sin calidad. En el siglo XVI parece ya consolidado el perfil de un profesional (pintor o escultor) preparado para satisfacer al público y casi en serie, gustos turbados por otros factores que no son solo los de la belleza medida, sino todo lo contrario: la estética de lo atormentado y la conmoción de lo devoto. Se creó una convivencia en dos niveles, el de los talleres de los grandes y el de los comercios o mercados como los de la calle de Santiago de Valladolid.

Las imágenes impresas en papel o seda decapitaron los intereses estéticos de aquellos personajes, exquisitos, sometidos a la tiranía de la pieza rara y única, viniendo el tiempo de la divulgación y la obra multiplicada.

ANTONIO CEA GUTTÉRREZ C.S.I.C., Madrid 
Al estudiar el coleccionismo y las devociones privadas en la Sierra de Francia y Candelario (Salamanca, siglos XVII-XIX) se analizan aquellos factores antropológicos, sociales, económicos, patrimoniales, estéticos, etc., que actúan como elementos integradores entre estos dos ejes principales: el arte y la religiosidad.

Those anthropological, social, economic, patrimonial and aesthetic factors that work as integrative elements between these two main central ideas -art and religious feelingsare analysed when we both study the collections and the private devotions in Sierra de Francia and Candelario (Salamanca, XVII th-XIX th centuries). 